JOÃO FLORÊNCIO DE SALLES GOMES JUNIOR

\title{
O CRIME DE APROPRIAÇÃO INDÉBITA NO DIREITO PENAL BRASILEIRO
}

UNIVERSIDADE DE SÃO PAULO

SÃO PAULO 


\title{
O CRIME DE APROPRIAÇÃO INDÉBITA NO DIREITO PENAL BRASILEIRO
}

\begin{abstract}
Tese apresentada à Banca Examinadora da Faculdade de Direito da Universidade de São Paulo, como exigência parcial para a obtenção do título de Doutor em Direito Penal, sob a orientação do Professor Titular Miguel Reale Júnior, do Departamento de Direito Penal, Medicina Forense e Criminologia da Faculdade de Direito da Universidade de São Paulo
\end{abstract}




\section{BANCA EXAMINADORA:}

Professor Titular Miguel Reale Júnior

(Orientador)

(Membro)

(Membro)

(Membro)

(Membro) 
Aos meus filhos,

Arthur de Salles Gomes, Alice de Salles Gomes e Gabriel de Salles Gomes.

Presença diária de Deus em minha vida. 


\section{RESUMO}

A doutrina e a jurisprudência brasileiras sobrevalorizam o elemento subjetivo do delito de apropriação indébita de tal forma que a própria ação típica é vista, muitas vezes, fundamentalmente como a mera exteriorização daquele elemento subjetivo, sem valor em si, de forma a fixar-se o momento consumativo apenas pela demonstração da inversão do animus da posse. Tal entendimento acaba por levar à atribuição, ainda que inconsciente, de um caráter formal ao delito de apropriação indébita. Assim, mesmo afirmando tratar-se de crime material, que admite tentativa, a maioria dos autores brasileiros acaba, na realidade, por inadmiti-la ou admiti-la de forma excessivamente restrita e casuística, sem dispor de qualquer critério sólido para aferi-la. De outro lado, a atribuição de natureza formal ao delito de apropriação indébita (explícita no direito italiano e implícita no direito brasileiro) pode levar à desproporcional punição, por crime consumado, de condutas que em nada atingiram o bem jurídico protegido pelo tipo penal, qual seja, a propriedade. O presente trabalho pretende resolver esse problema através da melhor compreensão da estrutura típica e da economia do delito de apropriação indébita. Para tanto, no primeiro capítulo, descreve-se o estado da questão, coloca-se o problema acima descrito e propõe-se um método para sua resolução. No segundo capítulo busca-se descrever, de forma sucinta, ainda que completa, os elementos típicos essenciais do crime de apropriação indébita para que, no terceiro capítulo, possa-se empreender o esforço interpretativo fundamental, relacionado à compreensão da estrutura e economia do delito em questão (o que envolve ampla consideração sobre a questão do bem jurídico), para, ao final, desvelar natureza (material ou formal) do delito e seu momento consumativo, de forma a resolver, sobre bases mais sólidas, a questão da tentativa. No capítulo 4, aplicam-se as soluções aventadas no decorrer do trabalho também às denominadas apropriações indébitas menores e ao peculato. 


\section{RIASSUNTO}

La dottrina e la giurisprudenza brasiliane sopravvalutano l'elemento soggettivo del reato d'appropriazione indebita a un tal punto, che la stessa azione tipica spesso si considera come la semplice esternalizzazione di detto elemento soggettivo, privo d'ogni valore in sé, e il momento di consumazione si fissa soltanto con la dimostrazione dell'inversione dell'animus del possesso. Questa comprensione conduce all'attribuzione (anche se inconscia) di un carattere formale al delitto di appropriazione indebita. In conseguenza, nonostante si affermi il carattere materiale di questo reato, la maggioranza degli autori brasiliani finisce nel negare, in pratica, la possibilità del tentativo o almeno nel ammetterlo restrittivamente e casisticamente, senza appoggio in precisi criteri per il raggiungimento di un'esatta soluzione. In questo modo, l'attribuzione di natura formale al reato di appropriazione indebita (esplicita nel diritto italiano e implicita nel brasiliano) può condurre a sproporzionate punizioni per consumato delitto, quando in realtà si tratterebbe di condotte che in nulla offenderebbero il bene giuridico protetto dalla fattispecie, cioè, la proprietà . Questo saggio ha l'intenzione di risolvere questo problema per mezzo di una migliore comprensione della fattispecie e dell'economia del delitto di appropriazione indebita. A questo scopo, nel primo capitolo si descrive lo status quaestionis, si pone il problema appena menzionato e si suggerisce un metodo per la soluzione. Nel secondo capitolo si cerca di descrivere, succintamente (ma in modo completo), gli elementi essenziali del reato di appropriazione indebita in modo che, nel terzo capitolo, si possa intraprendere il fondamentale sforzo interpretativo collegato alla comprensione della struttura e dell'economia del reato (cosa che coinvolge l'ampia considerazione sulla domanda del bene giuridico) e, al fine, rivelare la sua natura (materiale o formale) e il suo momento di consumazione: con questo si potrà risolvere il problema del tentativo su fondamenti più solidi. Nel quarto capitolo le soluzione ottenute nel corso di questo saggio vengono applicate anche alle così dette appropriazioni indebite minori e al peculato. 


\section{SUMMARY}

The Brazilian legal doctrine and jurisprudence overvalue the subjective element of the crime of embezzlement, in such a manner that the action itself is often basically considered as the simple exteriorization of such a subjective element, without any value in itself, so that the moment when it is carried out is established only by proving the reversal of the animus of possession. Such explanation finally produces the attribution, even if it's unconscious, of a formal character to the crime of embezzlement. Thus, even if it is considered that this is a specific crime, which allows all types of efforts, most Brazilian authors, in the end, tend to not admit such crimes or admit them only a limited and casuistic form, without having a solid criterion to assess them. In this manner, the attribution of the formal nature of the crime of embezzlement may bring about a disproportional penalty for the perpetration of behaviors against assets that did not achieve the status of protected legal assets, based on criminal offense types, without regard to the type of property. The objective of this work is to solve this problem by understanding in a better manner the structure of the crime of embezzlement. Therefore, in the first chapter, there is a description of this issue and the aforementioned problem. A method is proposed to solve this problem. In the second chapter, the typical and basic elements of the crime of embezzlement are described in a resumed and, nevertheless, complete manner, so that in the third chapter, the fundamental interpretative effort can be made. Such effort is related to understanding the structure of the mentioned crime (this involves an ample consideration of descriptions of legal assets.) At the end of this work, the nature of crimes will be revealed (which can be specific or have the formal features of the crime). When it has been possible to solve crimes based on more specific concepts, the issue that we tried to solve is explained. In the fourth chapter, the solutions suggested in this work are applied. Minor embezzlements and peculation are also described. 


\section{SUMÁRIO}

INTRODUÇÃO

1 ESTADO DA QUESTÃO E COLOCAÇÃO DO PROBELMA................................ 14

1.1 Estado da questão: A construção e a interpretação do tipo penal de apropriação indébita no Direito Penal brasileiro................................................... 14

1.2 Colocação do problema: estrutura típica e economia do delito de apropriação indébita no Direito Penal brasileiro................................................... 40

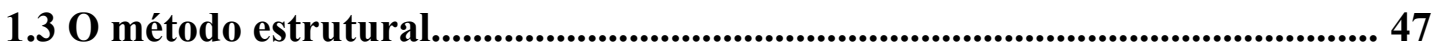

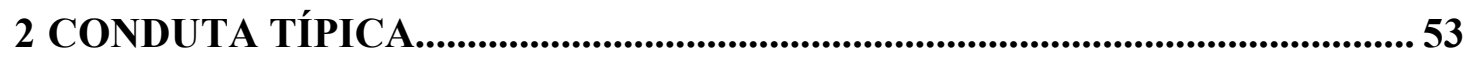

2.1 A formação histórica do tipo penal de apropriação indébita..........................54

2.2 A posse ou detenção de coisa alheia móvel................................................57

$2.3 \mathrm{O}$ animus rem sibi habendi....................................................................66

2.3 Conduta típica de apropriação indébita e suas modalidades....................... 70

3 ESTRUTURA TÍPICA E ECONOMIA DO DELITO: CONSUMAÇÃO E TENTATIVA DE APROPRIAÇÃO INDÉBITA NO DIREITO PENAL

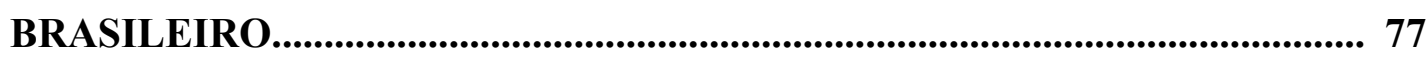

3.1 Recolocação do problema: as experiências brasileira e italiana................... 77

3.2 A relação entre tipo subjetivo e tipo objetivo no delito de apropriação indébita: a apropriação como pensamento e ação.................................................. 90

3.3 Tutela penal da propriedade e legitimidade do Direito Penal: a questão do bem jurídico protegido............................................................................................ 95

3.3.1 Interesses patrimoniais e Direito Penal................................................... 96

3.3.2 Objeto material, resultado típico e bem jurídico................................. 108 
3.4 Estrutura típica e economia do delito: a apropriação como ação e como resultado.

3.5 Consumação e tentativa de apropriação indébita no Direito Penal brasileiro.

4 CRIMES ASSEMELHADOS........................................................................... 124

4.1 Apropriação de coisa havida acidentalmente..................................................... 125

4.2 Apropriação de tesouro......................................................................................... 132

4.3 Apropriação de coisa achada.............................................................................. 135

4.4 Peculato-apropriação.................................................................................................... 141

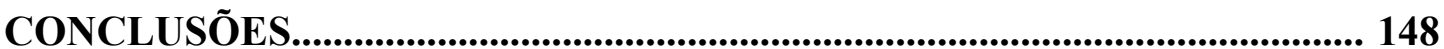

REFERÊNCIAS BIBLIOGRÁFICAS............................................................ 151 


\section{INTRODUÇÃ̃O}

Diante da ausência de obras monográficas ${ }^{1}$ sobre a apropriação indébita em nossa doutrina e da aplicação distorcida do tipo penal em nossa prática jurídica, vislumbrava-se, quando da apresentação do projeto de pesquisa, a possibilidade de que esse trabalho pudesse trazer alguma contribuição à ciência jurídica brasileira.

Desde aquele momento, já se antevia o problemático intrincamento entre os elementos típicos da apropriação indébita, razão pela qual já advertia o Professor Miguel Reale Júnior, na orientação do trabalho, para a necessidade de concentração na resolução do que é essencial e particular no tipo penal.

O próprio desenvolvimento da pesquisa restou por demonstrar que, de fato, a interpretação do tipo penal de apropriação indébita encontra, no Direito Penal brasileiro, agudas contradições e excessivo casuísmo.

Verificou-se que a doutrina e a jurisprudência brasileiras sobrevalorizam o elemento subjetivo do delito de apropriação indébita de tal forma que a própria ação típica é vista, muitas vezes, fundamentalmente como a mera exteriorização do elemento subjetivo, sem valor em si, de forma a fixar-se o momento consumativo apenas com a demonstração da inversão do animus da posse.

\footnotetext{
${ }^{1}$ No início do nosso interesse pelo tema, logo após a conclusão do mestrado, tivemos a oportunidade de sugerir ao orientando Rafael Mellega, da Faculdade de Direito da Universidade Metodista de Piracicaba, que desenvolvesse sua monografia de conclusão do curso de graduação. sobre a questão da consumação e tentativa de apropriação indébita no direito penal brasileiro. Vimos, com satisfação, o aplicado aluno acolher nossa sugestão de trabalho e apresentar referida monografia no ano de 2008. A singeleza do trabalho, própria da espécie e o fato de que o aluno não buscou, na verdade, critérios diversos daqueles já advogados pela nossa doutrina para a solução do problema, o que o levou a concluir, com fundamento em Régis Prado, pela impossibilidade da tentativa, impediu, porém, em que pese a boa qualidade de sua monografia, que esta pudesse trazer maiores subsídios ao presente trabalho, ou, também por sua natureza de iniciação científica, e também por falta de publicação, pudesse ser aqui considerada como obra monográfica sobre o tema.
} 
Tal entendimento acaba por levar à atribuição, ainda que inconsciente, de um caráter formal ao delito de apropriação indébita. Assim, mesmo afirmando se tratar de crime material, que admite tentativa, a maioria dos autores brasileiros acaba por na realidade inadmiti-la ou admiti-la de forma excessivamente restrita e casuística, sem utilizar qualquer critério sólido para aferi-la.

De outro lado, a atribuição de natureza formal ao delito de apropriação indébita (implícita no Direito brasileiro) pode levar à desproporcional punição, por crime consumado, de condutas que em nada atingiram o bem jurídico protegido pelo tipo penal, qual seja, a propriedade.

Na Itália, por sua vez, a tradicional doutrina penal sustenta explicitamente o caráter formal da conduta de apropriação indébita, o que permitiria o reconhecimento da tentativa somente nos casos de conduta plurissubsistente ainda não esgotada. Tal critério, importado ao Direito brasileiro, não obstante se afirme entre nós o caráter material do delito, gera, por evidente, importante contradição e a consequente insegurança na resolução dos casos concretos.

O presente trabalho pretende resolver esse problema através da melhor compreensão da estrutura típica e da economia do delito de apropriação indébita.

No primeiro capítulo, após a devida descrição do estado da questão, é colocado o problema relativo à interpretação do crime de apropriação indébita no Direito Penal brasileiro e apontada a adoção do método estrutural de compreensão da construção típica, proposto por Miguel Reale Júnior em suas Instituições de Direito Penal, como forma de reconstruir o raciocínio referente à estrutura típica do crime de forma mais adequada. 
Em decorrência da adoção do método estrutural, o segundo capítulo desse trabalho é dedicado à apreensão do invariável elementar do crime de apropriação indébita, através da observação e análise dos elementos essenciais do tipo penal: a pressuposta posse lícita, o animus rem sibi habendi, e a própria ação de apropriação, em suas diversas modalidades (consumo, disposição ou alheação, retenção e desvio).

No terceiro capítulo, empreende-se o esforço interpretativo fundamental, relacionado à compreensão da estrutura e economia do delito em questão (o que envolve ampla consideração sobre a questão do bem jurídico), para, ao final, desvelar a natureza (material ou formal) do delito e seu momento consumativo, de forma a resolver, sobre bases mais sólidas, a questão da tentativa.

O quarto capítulo dedica-se a melhor resolver algumas questões pontuais das chamadas apropriações indébitas menores e do peculato, com fundamento na nova compreensão da estrutura típica do delito desenvolvida nos capítulos anteriores.

De resto, é importante notar que, na realização desse trabalho, procurou-se revelar principalmente a realidade do sistema penal brasileiro. Dessa forma, o texto refere-se, de forma significativa, à jurisprudência e à doutrina que mais influência têm exercido na prática do nosso Direito Penal, por vezes distantes, infelizmente, das contribuições acadêmicas melhor elaboradas (o que nos impôs o dever da crítica).

O recurso aos melhores autores brasileiros que se dedicaram à parte especial do direito Penal, como Hungria, Noronha e Fragoso e à moderna doutrina estrangeira, especialmente à italiana e à espanhola, permitiu, no entanto, que se superasse tais limitações. 
Por fim, ao optar-se pelo desenvolvimento de um trabalho concentrado na compreensão da estrutura típica do crime de apropriação indébita e suas consequências para o tema da consumação e tentativa deste delito, deixouse de aprofundar interessantes questões relacionadas a outros aspectos do tipo penal, tais como a extensa discussão sobre a distinção entre posse e detenção, para fins penais, muito presente no Direito italiano e o interessante desenvolvimento do conceito de abuso de confiança no Direito Penal francês. 


\section{ESTADO DA QUESTÃO E COLOCAÇÃO DO PROBLEMA.}

SUMÁRIO: 1.1 Estado da questão: A construção e a interpretação do tipo penal de apropriação indébita no Direito Penal brasileiro. 1.2 Colocação do problema: Estrutura típica e economia do delito de apropriação indébita no Direito Penal brasileiro. 1.3 O método estrutural.

\subsection{Estado da questão: A construção e a interpretação do tipo penal de} apropriação indébita no Direito Penal brasileiro.

Após interessante processo histórico de separação legal do crime de furto, reconhece-se, também no campo doutrinário e jurisprudencial, a necessária autonomia do crime de apropriação indébita.

Como bem sintetizado por Heleno Fragoso, "não se distinguia, no direito romano, do furto, o crime que nosso código denomina apropriação indébita, a exemplo do antigo código sardo. Desde a Idade Média, porém, era o fato considerado furtum improprium, no qual se reconhecia uma contrectatio ficta, com pena mais branda do que a cominada ao furto. (...) Deve-se ao Código Penal francês de 1791 a configuração de crime autônomo, com o nome de abuso de confiança, adotado também no código napoleônico, e, por influência deste, nos 
códigos português e suíço. O código toscano, de 1853 (art. 396), o denominava truffa, e o código alemão (§ 246), desvio (Unterschlagung)". ${ }^{2}$

No Brasil, ainda segundo Fragoso, as "Ordenações Filipinas previam uma modalidade do crime que se configurava nos casos em que as coisas que constituíam objeto material da ação fossem entregues ao agente 'por vontade de seus donos' (...). O mesmo critério foi seguido pelo CP de 1890 (art. 331), evidentemente atrasado. (...) O nomem iuris, 'apropriação indébita', era desconhecido da nossa legislação anterior, posto que fosse corrente na jurisprudência, sendo empregado na legislação italiana desde o código sardo". 3

Com a edição do Código de 1940 reconhece-se entre nós a autonomia da apropriação indébita em relação ao furto, sendo esta definida, no artigo 168, como o ato de "apropriar-se de coisa alheia móvel, de que tem a posse ou a detenção". Estabelecem-se, ainda, no artigo 169, as figuras típicas da apropriação de coisa havida por erro, caso fortuito ou força da natureza, da apropriação de tesouro e da apropriação de coisa achada.

Desde então, os atos concretos de apropriação indébita vêm desafiando a melhor doutrina, quer pela dificuldade técnica de compreensão da intrincada relação entre seus elementos objetivos e subjetivos, quer pela necessidade de resolução mais segura da questão do momento consumativo e, consequentemente, da possibilidade ou impossibilidade de tentativa do delito.

O exemplo peninsular é de interesse, até mesmo pelo lastro comum do Código Rocco, de 1930, fonte inspiradora da Parte Especial brasileira, de 1940, ainda em vigor. Moccia, em visão crítica do problema, destaca a hipervalorização do patrimônio naquela codificação, utilizando-se do exemplo do

\footnotetext{
${ }^{2}$ Fragoso, Heleno Cláudio, Lições de Direito Penal - Parte Especial, vol. I, $8^{\mathrm{a}}$ ed., Rio de Janeiro, Forense, 1986. pp. 353-354.

${ }^{3}$ Idem. p. 354.
} 
crime de furto. ${ }^{4}$ Além disso, destaca a evolução da leitura constitucional italiana acerca dessas ponderações. ${ }^{5}$

Tais evoluções no caudaloso campo dos crimes ligados às noções da posse e da propriedade também são encontradas em outras realidades nacionais e são fruto de mudanças na orientação das interpretações, mas não só. Alterações legislativas também obraram nesse sentido. O Brasil, no entanto, permanece estático em muitas de suas construções clássicas, as quais, não raro, pecam em sua lógica. Esse, o caso da apropriação indébita.

Nesse contexto, ganha destaque, pela sua fundamental influência na posterior conformação da doutrina e jurisprudência brasileiras, os comentários de Nélson Hungria sobre o tipo penal em questão. Recorde-se que Hungria se mostra como um dos mais destacados penalistas do século XX, deitando reflexo em boa parte das obras que lhe são posteriores. ${ }^{6}$ Essa, aliás, a razão básica e primordial da ancoragem inicial em seu pensamento, tendo tal como base para posterior debate.

Após elogiar a redação legislativa, no que diz respeito à adoção do título apropriação indébita e à formulação idêntica à do Código Penal alemão ${ }^{7}$, apenas com a supressão, correta a seu ver, da menção à ilegalidade da apropriação, Hungria destaca a opção pelo silêncio legislativo quanto ao elemento confiança, presente em diversos códigos afeiçoados ao modelo francês. ${ }^{8}$

\footnotetext{
${ }^{4}$ Moccia, Sergio, Tutela Penale del Patrimonio e Principi Constituzionale, Padova, CEDAM, 1988. pp. 13 e ss. ${ }^{5}$ Idem, pp. 25 e ss.

${ }^{6}$ Cf. Bueno, Paulo Thomaz Alves da Cunha, Notícia Histórica do Direito Penal no Brasil, in BiTTAR, Eduardo C.B, História do Direito Brasileiro - Leituras da Ordem Jurídica Nacional, São Paulo, Atlas, 2003. pp. 153 e ss. JimenEZ DE ASÚA, Luis. Tratado de Derecho Penal, vol. 1, Buenos Aires, Lousada, 1950. pp. 1067 e ss.

7 Em sua redação original: $\S 246$. Apropriação indébita. (1) Quem ilicitamente se apropria de coisa alheia móvel de que tem a posse ou detenção é punido, por apropriação indébita, com prisão até três anos ou com multa; e quando a coisa lhe foi entregue em confiança, com prisão até cinco anos ou com multa. (2) A tentativa é punível. (Código Penal Alemão, trad. de Lauro de Almeida, São Paulo, Bushatsky, 1974. p. 204).

${ }^{8}$ Hungria, Nélson, Comentários ao Código Penal, vol. VII, Rio de Janeiro, Forense, 1955. p. 124.
} 
Para Hungria, crítico do modelo francês ${ }^{9}$, que considera ultrapassado, "a fidúcia pode intervir, e é mesmo nota frequente do crime, importando, aliás, em casos especiais, condição de maior punibilidade; mas não deve ser considerada elemento imprescindível: pode ocorrer o crime sem que interfira abuso de confiança ou um fidem fallere, como, entre vários exemplos, no

${ }^{9}$ Estabelecia o antigo Código Penal Francês, em seu artigo 408 e sob a rubrica de abuso de confiança que, "qualquer um que tenha desviado ou dissipado em prejuízo dos proprietários, possuidores ou detentores dos títulos de crédito, tributos, mercadorias, letras, quitações ou todos os outros documentos contendo ou estabelecendo obrigação ou desobrigação, que lhe teriam sido entregues apenas a título de aluguel, de depósito, de mandato, de fiança, de empréstimo para uso ${ }^{9}$ ou para trabalho remunerado ou não remunerado, com a obrigação de devolvê-los ou reapresentá-los, ou deles fazer uso ou emprego determinado, será punido com penas estabelecidas pelo artigo 406. Tudo isso sem prejuízo do que é previsto nos artigos 254, 255 e 256, relativamente a subtração e retirada de valores, títulos cometidos em depósitos públicos - Quiconque aura détourné ou dissipé au préjudice des propriétaires, possesseurs ou détenteurs, des effets, deniers, marchandises, billets, quittances ou tous autres écrits contenant ou opérant obligation ou décharge, qui ne lui auraient été remis qu'à titre de louage, de dépôt, de mandat, de nantissement, de prêt à usage, ou pour un travail salarié ou non salarié, à la charge de les rendre ou représenter, ou d'en faire un usage ou un emploi déterminé, sera puni des peines portées en l'article 406. Le tout, sans préjudice de ce qui est dit aux articles 254, 255 et 256, relativement aux soustractions et enlèvements de deniers, effets ou pièces, commis dans les dépôts publics (traducão nossa).

O atual Código Penal francês estabelece que : Art. 314-1 O abuso de confiança é o ato de uma pessoa desviar, em prejuízo de outro, fundos, valores ou qualquer bem que lhe tenham sido entregues e que a pessoa aceitou com a obrigação de devolvê-los, de reapresentá-los ou deles fazer um uso determinado. O abuso de confiança é punido com três anos de prisão e multa de 375.000 euros.

Art. 314-2 As penas são elevadas a sete anos de prisão e 750.000 euros de multa quando o abuso de confiança é realizado: $1^{\circ}$ Por pessoa que lança uma subscrição pública a fim de levantar fundos ou de valores, seja por sua própria conta, seja como dirigente ou preposto de direito ou de fato de uma empresa industrial ou comercial; $2^{\circ}$ Por qualquer outra pessoa que, de modo habitual, dedica-se ou empresta seu apoio, mesmo a título acessório a operações relativas a bens de terceiros por conta dos quais a pessoa levanta fundos ou valores. $3^{\circ} \mathrm{Em}$ prejuízo de uma associação que lança uma subscrição pública com o objetivo de coletar fundos para fins de ajuda humanitária ou social; $4^{\circ} \mathrm{Em}$ prejuízo de uma pessoa cuja particular vulnerabilidade, devido a sua idade, doença, invalidez, deficiência física ou psíquica ou gravidez é aparente ou conhecida de seu autor. Art. 314-3 - As penas são elevadas a dez anos de prisão e a 1.5000 .000 euros de multa quando o abuso de confiança é realizado por um procurador legal ou por um agente público ou ministerial seja no exercício ou à ocasião do exercício de suas funções, seja em razão de sua qualidade. - Art. 314-1 - L'abus de confiance est le fait par une personne de détourner, au préjudice d'autrui, des fonds, des valeurs ou un bien quelconque qui lui ont été remis et qu'elle a acceptés à charge de les rendre, de les représenter ou d'en faire un usage déterminé. L'abus de confiance est puni de trois ans d'emprisonnement et de $375000 €$ d'amende. Art. 314-2 - Les peines son portées à sept ans d'emprisonnement et à $750000 €$ d'amende lorsque l'abus de confiance est réalisé: $1^{\circ}$ Par une personne qui fait appel au public afin d'obtenir la remise de fonds ou de valeurs soit pour son propre compte, soit comme dirigeant ou préposé de droit ou de fait d'une entreprise industrielle ou commerciale; $2^{\circ}$ Par toute autre personne qui, de manière habituelle, se livre ou prête son concours, même à titre accessoire, à des opérations portant sur les biens des tiers pour le compte desquels elle recouvre des fonds ou des valeurs. $3^{\circ} \mathrm{Au}$ préjudice d'une association qui fait appel au public en vue de la collecte des fonds à des fins d'entraide humanitaire ou sociale; $4^{\circ} \mathrm{Au}$ préjudice d'une personne dont la particulière vulnérabilité, due à son âge, à une maladie, à une infirmité, à une déficience physique ou psychique ou à un état de grossesse, est apparente ou connue de son auteur. Art. 314-3 - Les peines son portées à dix ans d'emprisonnement et à $1500000 €$ d'amende lorsque l'abus de confiance est réalisé par un madataire de justice ou par un officier public ou ministeriel soit dans l'exercice ou à l'occasion de l'exercice de ses fonctions, soit en raison de sa qualité. 
caso do ímprobo negotiorum gestor, ou em que o precedente poder de disposição física da coisa tenha resultado ope legis". ${ }^{10}$

Destaca ainda, nesse ponto, que "se se pode falar, na espécie, em infidelidade, de modo genérico, é a do agente em relação ao título da posse ou detenção, que ele converte, de ajustado, permitido ou tolerado poder de disponibilidade a título provisório ou precário, em poder de disponibilidade $u t i$ dominus", concluindo que "o que é necessário e suficiente é que à ilícita apropriação preexista a justa posse ou detenção exercida pelo agente, alieno domine, sobre a coisa". ${ }^{11}$

Quanto à ação típica, logo após breve definição do crime de apropriação indébita e distinção entre este e o furto, Hungria concentra seus esforços em demonstrar, vigorosamente, como de costume, a necessidade de se aferir, com rigor e critério, a presença do elemento subjetivo especial do tipo penal como forma de diferenciar o ilícito penal do ilícito civil.

É dessa forma que se compreende a colocação inicial de Hungria segundo a qual "quando a coisa continua em poder do agente, ou não tenha sido por ele alienada ou consumida, cumpre ter em atenção que a simples negativa de restituição ou omissão de emprego ao fim determinado não significa, ainda que contra jus, necessária e irremissivelmente, apropriação indébita: para que esta se apresente, é indispensável que a negativa ou omissão seja precedida ou acompanhada de circunstâncias que inequivocamente revelem o arbitrário animus rem sibi habendi, ou que não haja, de todo, qualquer fundamento legal ou motivo razoável para a recusa ou omissão". ${ }^{12}$

Nesse ponto, o autor adverte que "a simples mora em restituir, ou a simples desídia no omitir não é apropriação. É preciso, antes de tudo, não

\footnotetext{
${ }^{10}$ Hungria, Nélson, op. cit., p. 124.

${ }^{11}$ Idem. Ibidem.

${ }^{12}$ Idem. p. 131.
} 
confundir com apropriação indébita os casos em que apenas cabe recurso ao juízo civil". ${ }^{13}$

A importância de tal advertência deriva, segundo o próprio Hungria, da constatação dos inúmeros casos em que o credor recorre ao juízo penal tentando colorir de apropriação indébita o que não passa de mero inadimplemento contratual.

Para Hungria, esse problema de reconhecimento da apropriação indébita é uma questão a ser de fato resolvida caso a caso pelo juiz. A chave de resolução da questão, para o autor, é a averiguação do propósito de não mais restituir ou a consciência de não mais poder restituir. Assim, para Hungria, não comete apropriação indébita "um credor pignoratício que, por uma necessidade momentânea de dinheiro, faz um arbitrário subpenhor da coisa recebida em garantia, mas com a intenção de ulterior resgate e oportuna restituição, e tendo capacidade financeira para tanto". ${ }^{14}$

Reconhece Hungria, então, a absoluta necessidade do animus rem sibi habendi para a concretização do delito, negando, no entanto, que este configure dolo específico, como então era denominado.

Com efeito, afirma Hungria que "como a apropriação pressupõe, conceitualmente, a intenção definitiva de não restituir a coisa ou desviá-la do fim para que foi entregue, ou a ciência de que se torna impraticável uma coisa ou outra, é óbvio que tal intenção ou ciência é integrante do dolo do agente. A ausência do animus rem sibi habendi exclui, subjetivamente, a apropriação indébita. Não se há de falar aqui em dolo específico (pois é indiferente qualquer fim ulterior à apropriação), mas em dolo genérico, isto é, a vontade ou consciência da ação típica do crime, que, no caso, é a apropriação sine

\footnotetext{
${ }^{13}$ HungRIA, Nélson, op. cit., p. 131.

${ }^{14}$ Idem. p. 132.
} 
jure da coisa alheia. A apropriação é o elemento de fato do crime, e não um fim ulterior do agente". ${ }^{15}$

Analisados os elementos do tipo penal, chega-se, ainda em Hungria, à fundamental questão da consumação.

Chama a atenção, de início, que Hungria abandone a sua tradicional assertividade de julgamento para advogar que "para a identificação do momento consumativo da apropriação indébita não se pode adotar um critério rígido ou imutável". ${ }^{16}$

Para o autor, "em princípio, tal momento surge com o ato de apropriação, sendo irrelevante indagar (ao contrário do que ocorre com o estelionato) se o agente conseguiu efetivamente, ou não, o ilícito proveito visado. Entretanto, quando o agente recusa devolver, não obstante solicitação de quem de direito, a coisa possuída ou detida nomine alieno, e não se apresenta averiguado um anterior ato material iniludivelmente indicativo da arbitrária apropriação, é força admitir que o momento da consumação é o da negativa da restituição, ainda que realmente tenha sido outro". ${ }^{17}$

Prossegue Hungria, afirmando que "se a coisa continua em poder do agente, e tendo-se em vista que, antes do pedido de restituição, o uso que ele faça da coisa, ainda que contra jus, mas sem o animus rem sibi habendi, constitui mero ilícito civil (abuso da posse), não se pode determinar, na ausência de prova de qualquer fato inequívoco (como, por exemplo, o escondimento da coisa), o momento em que teria sido realmente transformada em posse uti dominus a posse ou detenção exercida em nome alheio. Consequência necessária será, então, considerar como momento consumativo o da recusa de devolução da coisa. Outra solução não é possível, a não ser que se pudesse fazer uma exploratio mentis, independentemente de fatos externos ou objetivos, para fixar o momento

\footnotetext{
${ }^{15}$ HungRIA, Nélson, op. cit., p. 134.

${ }^{16}$ Idem. p. 138.

${ }^{17}$ Idem. pp. 138-139.
} 
em que o agente resolveu inverter o título da posse ou detenção. E outra solução não comporta o próprio caso em que a coisa já tenha sido desviada para o poder de terceiros ou dissipada, mas não se podendo provar tais fatos". ${ }^{18}$

Ainda nesse sentido, o autor faz questão de ressaltar que "é em razão da inexistência de prova de um precedente ato inequívoco de apropriação que se tem de transferir o momento consumativo para o ato da negada restituição (se é que esta realmente não coincida com a apropriação)". ${ }^{19}$

Sobre a recusa de a restituição representar o momento consumativo do delito ou apenas a sua prova, socorre-se Hungria do pensamento de Irueta Goyena, para quem as duas teses são exatas. Para esse autor, "a maneira mais sábia, talvez, de atalhar muitos litígios é ficar com as opiniões aparentemente antagônicas. Quando Zadig, o personagem de Voltaire, foi chamado ao governo da Pérsia, a encontrou dividida em dois partidos absolutamente irreconciliáveis. Uns entendiam que se devia entrar no templo avançando o pé direito, e outros o pé esquerdo. Zadig resolveu o problema, que tanto agitava a opinião pública, penetrando na augusta mansão com os pés juntos. A respeito do problema em debate, é de aconselhar-se a tática de Zadig, que é, porventura, o melhor modo de sobrepor-se ao bizantinismo das discussões: a negativa de restituição, umas vezes, é prova da consumação e, outras, representa a consumação". ${ }^{20}$

Para o autor, deve ficar claro que "a negativa de restituição só é verdadeiramente consumação quando coincide, objetiva e subjetivamente, com o ato de apropriação; nos demais casos, por isso que é um momento posterior ao ato de apropriação (momento consumativo), não se confunde com este, de que somente pode ser prova; mas, se não se consegue apurar devidamente o ato anterior de apropriação, não há como deixar de referir ao ato de negativa de restituição, ainda que por uma fictio, o momento consumativo. A prova de

\footnotetext{
${ }^{18}$ Hungria, Nélson, op. cit., p.138-139.

${ }^{19}$ Idem. p. 139.

${ }^{20}$ Idem. p. 141.
} 
inequívoco ato anterior de apropriação é indispensável para que a ele se remonte o summatum opus, caso contrário, o único ponto de referência, para identificar-se a consumação, é o momento da recusa de restituição. A esta se equipara a omissão de restituição ardilosamente dissimulada. Também nesse caso, se inexiste prova de característico ato de apropriação, ter-se-á de fixar como momento consumativo o da omitida restituição. Tome-se o caso do administrador que, ao prestar contas, simula fatos inexistentes, para encobrir um desfalque de valores: se não se consegue provar quando ele indevidamente se apropriou de tais valores, não se pode deixar de considerar como momento consumativo, embora realmente não o seja, o momento da fraudulenta prestação de contas, isto é, o da não entrega do verdadeiro saldo. Ao contrário, se se alcança provar um ato de anterior apropriação (ex., a aquisição, por parte do agente, de bens por preço inacessível à sua bolsa ou crédito), a esse ato se tem de referir o momento consumativo, nada importando que, na sua data, não estivesse expirado o prazo para a prestação de contas ou entrega do saldo. Suponha-se, agora, que o administrador se recuse a prestar contas amigavelmente e não se apresente fato algum positivo de sua infidelidade: terá de ser chamado a prestar contas em juízo (a prestação de contas, amigável ou judicial, é indispensável ao reconhecimento da apropriação indébita quando haja reciprocidade de créditos e débitos compensáveis entre o agente e o dominus, e inexista prova de precedente e inequívoco ato de arbitrária apropriação), e, apurado o desfalque, o momento consumativo retroagirá à data da citação inicial". ${ }^{21}$

Verifica-se, portanto, que Hungria concentra o seu raciocínio sobre a questão da consumação do crime de apropriação indébita na inversão do animus, fixando-a, na verdade, no momento em que surge o elemento subjetivo do tipo. Fica claro em seu pensamento que a ação externa realizada pelo agente — de disposição ou consumo da coisa, por exemplo — nada mais seria que, tão somente, a prova da apropriação indébita já consumada.

\footnotetext{
${ }^{21}$ Hungria, Nélson, op. cit., p.141.
} 
Dessa forma, ao tratar da ação típica e também da consumação, Hungria acaba por fixar seu olhar quase que exclusivamente sobre o elemento subjetivo do tipo penal. Para ele o surgimento do animus rem sibi habendi se sobrepõe à própria conduta externa e à eventual violação da propriedade na fixação do início da execução e do momento consumativo do delito. Tais elementos típicos parecem, em Hungria, ter função limitada à revelação do animus, como realidade fundamental do delito.

Nesse ponto, é capital notar que a posição de Hungria sobre a tentativa de apropriação indébita parece contradizer sua posição sobre a consumação do delito.

É de se verificar, quanto a isso, que Hungria não só admite a tentativa de apropriação indébita como critica os que não a consideram possível: "Não acolhemos a opinião daqueles que entendem não ser possível a tentativa da apropriação indébita. É ela configurável não apenas no exemplo clássico do mensageiro infiel que é surpreendido no momento de violar o envelope que sabe conter valores, senão também toda a vez que a apropriação encerra um iter ou, como diz Hafter, se executa mediante um ato reconhecível ab externo (einen äusserlich erkennbaren Akt) como a venda e o penhor". ${ }^{22}$

Para o autor, "somente não se pode identificar a tentativa quando o ato de vontade do agente não é perceptível exteriormente, pois, em tal caso, segundo pondera Manzini, inexiste uma transição executiva da intenção para o ato consumativo", sendo de todo equivocadas as posições de outros autores que veem consumação do crime de apropriação indébita, antes da traditio, na veiculação de anúncios de venda ou no acordo sobre o preço da coisa. ${ }^{23}$

Parece evidente que tal posição não se coaduna com a fixação do critério de consumação na verificação da inversão do animus da posse, como proposto pelo próprio Hungria. Por acaso, não agiria com animus domino

\footnotetext{
${ }^{22}$ Hungria, Nélson, op. cit., p.141.

${ }^{23}$ Idem. Ibidem.
} 
aquele que põe à venda bem de que não pode dispor? Fixando-se a consumação no momento do surgimento do animus rem sibi abendi não estaria consumado o delito no momento do anúncio, inviabilizando o reconhecimento da tentativa?

Diante desse quadro, é de se destacar que os autores dos manuais contemporâneos, baseados fundamentalmente no pensamento de Hungria, e com imediata influência sobre a formação dos atuais operadores do direito, pouco avançam na explicação ou superação da aparente contradição.

Em geral, o que se vê, é a omissão diante da necessária tomada de posição ou a reprodução, total ou parcial, mais ou menos explícita, do pensamento de Hungria, no qual o elemento subjetivo protagoniza, quase por completo, o raciocínio sobre a consumação e a tentativa.

Dessa forma, Júlio Mirabete, por exemplo, afirma que “difícil é a apuração do momento consumativo do crime de apropriação indébita, uma vez que depende ele, exclusivamente, de circunstância subjetiva. A consumação opera-se quando o agente transforma a posse ou detenção em propriedade, ou seja, quando se inverte a posse em domínio. Na maioria dos casos, essa disposição é revelada por uma conduta externa do agente, incompatível com a vontade de restituir ou de dar o destino certo à coisa: venda, desvio, ocultação ou negativa expressa de não devolvê-la a quem de direito. A apuração do momento da consumação cria problemas práticos quanto à competência para o processo, determinada, em regra, pelo local da consumação. Por isso, tem-se decidido que se consuma o crime no lugar onde o agente converte em proveito próprio a coisa que devia restituir e não no do eleito pelas partes pelo contrato. No caso de caixeiros-viajantes, cobradores etc. tem-se entendido que o foro é do local onde o agente deve prestar contas" 24 , destacando, no entanto, em contradição adicional, que a presença do prejuízo, nos crimes de apropriação indébita, seria pressuposto indeclinável para o reconhecimento do ilícito.

\footnotetext{
${ }^{24}$ Mirabete, Júlio Fabbrini, Manual de Direito Penal, vol. 2, 26 a ed., São Paulo, Atlas, 2009. p.249.
} 
Damásio de Jesus, em outro exemplo, sequer aborda a questão controvertida da consumação, limitando-se a afirmar que "na apropriação indébita propriamente dita, o delito se consuma com o ato de disposição. Ex.: o sujeito vende o objeto material de que tinha a posse ou a detenção", enquanto "na negativa de restituição o crime atinge o momento consumativo quando o sujeito se recusa a devolver o objeto material". ${ }^{25}$

Para Roberto Bittencourt, "o momento consumativo do crime de apropriação indébita, convém registrar de plano, é de difícil precisão, pois depende, em última análise, de uma atitude subjetiva". ${ }^{26}$

Nesse sentido, o autor parece concordar com todos os aspectos do raciocínio de Hungria ao afirmar que "a consumação da apropriação indébita e, por extensão, o aperfeiçoamento do tipo coincidem com aquele momento em que o agente, por ato voluntário e consciente, inverte o título da posse exercida sobre a coisa, passando a dela dispor como se proprietário fosse. Contudo, a certeza da recusa em devolver a coisa somente se caracteriza por algum ato externo, típico de domínio, como o ânimo de apropriar-se dela"27. Bittencourt continua: "O animus rem sibi habendi, característico do crime de apropriação indébita, precisa ficar demonstrado à saciedade. Se o agente não manifesta a intenção de ficar com a res, e, ao contrário, decide restituí-la à vítima tão logo possível, o dolo da apropriação indébita não se aperfeiçoa. A simples demora na devolução da res, quando não existe prazo previsto para tanto, não caracteriza o delito de apropriação indébita" ${ }^{28}$. Para ao final asseverar que o crime de apropriação indébita “consuma-se, enfim, com a inversão da natureza da posse, caracterizada por ato demonstrativo de disposição da coisa alheia ou pela negativa em devolvê-la". ${ }^{29}$

\footnotetext{
${ }^{25}$ Jesus, Damásio Evangelista de, Direito Penal, vol. 2, São Paulo, Saraiva, 1997. p. 415.

${ }^{26}$ BitenCourt, Cezar Roberto, Tratado de Direito Penal - Parte Especial, vol. 3, São Paulo, Saraiva, 2009. p.199.

${ }^{27}$ Idem. Ibidem.

${ }^{28}$ Idem. Ibidem.

${ }^{29}$ Idem. Ibidem.
} 
Não há, é importante notar, qualquer crítica ao posicionamento de Hungria ou mesmo qualquer tentativa de rediscutir ou aprofundar o debate sobre o momento de consumação da apropriação indébita.

Embora não aprofunde a questão, Fernando Capez parece avaliar melhor a necessidade de ato externo para a consumação do crime de apropriação indébita ao afirmar que este é um crime material que se consuma "no momento em que o agente transforma a posse ou detenção sobre o objeto em domínio, ou seja, quando passa a agir como se fosse dono da coisa. A inversão do ânimo é demonstrada pela própria conduta do agente, que passa a adotar comportamentos incompatíveis com a mera posse ou detenção da coisa" ${ }^{30}$

Não há, no entanto, um melhor desenvolvimento da questão, tampouco a colocação do problema nos seus devidos termos, para melhor compreensão dos fundamentos de seu posicionamento.

Rogério Greco, por sua vez, aponta a conhecida e sempre lembrada dificuldade de resolução do problema da consumação do crime de apropriação indébita destacando que não se poderia "afirmar, com segurança, em que momento surgiu no agente a vontade de ter a coisa para si, como se fosse dono, invertendo o título da posse", para em seguida advogar que "podemos destacar alguns momentos de exteriorização da vontade, característicos daquele que atua com o dolo relativo ao delito do art. 168 do Código Penal, consumandose, pois, a infração penal". 31

Nesse ponto, parece-nos claro que o autor, entre tantos outros, segue integralmente e sem reparo a concepção exposta por Hungria segundo a qual a realização do ato externo configurador da apropriação indébita deve ser tomada como momento de consumação do crime tão somente por revelar o

\footnotetext{
${ }^{30}$ CAPEZ, Fernando, Curso de Direito Penal - Parte Especial, vol. 2, São Paulo, Saraiva, 2011. p. 542.

${ }^{31}$ GRECO, Rogério, Curso de Direito Penal - Parte Especial, vol. 3, Niterói, Impetus, 2006. p. 221.
} 
animus rem sibi abendi, e não por qualquer razão relacionada à necessidade de exteriorização de conduta lesiva.

Greco deixa ainda mais claro esse partido analítico afirmando que “conforme preceitua Álvaro Mayrink da Costa, podemos visualizar a consumação da apropriação indébita quando o agente, exteriorizando o seu animus rem sibi habendi, atua: a) por consumo - no qual há alteração ou transformação da coisa, o que impossibilita a sua restituição; b) por retenção recusa na devolução ou em dar a coisa; c) por alheação - passar a coisa a terceiro por venda, doação ou permuta, destinação que fora especificada no recebimento; d) por ocultação - que é uma forma de consumo; e) por desvio - aplicar um fim distinto trazendo prejuízo patrimonial (v.g.: Caio coloca à venda o relógio recebido em custódia; Tício retém dinheiro referente a comissões recebidas na mediação na venda de bens). Consoante tal visão, pode-se sintetizar que na tipificação, o ilícito comportamental se caracteriza diante da recusa da devolução da coisa, pois o autor possui um dever jurídico de restituir". 32

Prado, por sua vez, limita-se a afirmar, no quadro sinótico de seu manual, que a consumação do crime de apropriação indébita "ocorre no momento em que o sujeito ativo inverte o título da posse ou detenção, com animus rem sibi habendi, ${ }^{33}$, aderindo, à concepção de Hungria sobre o tema.

Fica-se com a impressão, por vezes, que o assunto nem mesmo mereceria discussão. Guilherme Nucci, por exemplo, se dá por satisfeito tão somente afirmando que a consumação se dá "quando ocorrer a apropriação da coisa alheia"34, sem qualquer outra consideração sobre o assunto.

\footnotetext{
${ }^{32}$ GRECO, Rogério, op. cit., p. 221.

${ }^{33}$ Prado, Luiz Regis, Curso de Direito Penal Brasileiro - Parte Especial, arts. 121 a 183, São Paulo, Revista dos Tribunais, 2000. p.476.

${ }^{34}$ NuCCI, Guilherme de Souza, Manual de Direito Penal - Parte Geral - Parte Especial, São Paulo, Revista dos Tribunais, 2005. p. 696.
} 
Enfim, ao que parece, nossa doutrina mais recente não pretendeu enfrentar a questão da consumação de forma mais profunda, limitandose a aderir, no mais das vezes sem menção expressa, ao pensamento de Hungria.

No que diz respeito à tentativa, o cenário não parece significativamente diferente. Pelo contrário, as intervenções críticas dos autores mais modernos, quando ocorrem, mais parecem evidenciar a contradição presente no pensamento de Hungria, chegando mesmo a aprofundá-la.

Assim, temos, em Mirabete, que "na verdade, os exemplos citados para apoiar essa orientação" — da possibilidade de tentativa do delito de apropriação indébita — "como o caso do mensageiro infiel que é surpreendido ao abrir o invólucro que contém valores, para deles apropriar-se, para nós configura crime consumado, já que existem a posse e o animus rem sibi habendi". ${ }^{35}$

Parece claro que tal assertiva leva às últimas consequências a visão segundo a qual toda a estrutura do delito de apropriação indébita orbita em volta do elemento subjetivo, que, por si só, marcaria os momentos da execução e da consumação do delito.

Nos demais autores, sequer há novas controvérsias a serem enfrentadas.

Bittencourt admite a tentativa limitando-se a expor o pensamento de Hungria sobre o tema, para concluir que "a despeito da dificuldade de sua comprovação, a identificação da tentativa fica na dependência da possibilidade concreta de se constatar a exteriorização do ato de vontade do sujeito ativo, capaz de demonstrar a alteração da intenção do agente de apropriarse da coisa alheia. Não se pode negar a configuração da tentativa quando, por exemplo, o proprietário surpreende o possuidor efetuando a venda de coisa que

${ }^{35}$ Mirabete, Júlio Fabbrini, op. cit., p. 249. 
lhe pertence e somente a intervenção daquele - circunstância alheia a vontade do agente - impede a tradição da coisa ao comprador" ${ }^{36}$

Greco parece também acompanhar o raciocínio de Hungria ao afirmar que "embora exista controvérsia doutrinária, tratando-se, como regra, de crime plurissubsistente, será perfeitamente admissível o raciocínio correspondente à tentativa no delito de apropriação indébita. Assim, o agente poderá, por exemplo, estar iniciando a prática de atos tendentes a se desfazer da coisa alheia móvel que se encontrava legitimamente em seu poder, quando é surpreendido pela própria vítima, que impede a transação criminosa. Por outro lado, quando o agente se recusa a devolver a coisa, depois de solicitada diretamente pela vítima, não se consegue visualizar a tentativa pelo fato de que, nesse exemplo, estaremos diante de um crime unissubsistente, ou seja, todos os atos que fazem parte do iter criminis foram concentrados na negativa verbal em devolver a coisa, consumando-se, nesse momento, a infração penal. Portanto, a análise da possibilidade referente à tentativa deverá ser levada a efeito caso a caso e, dependendo da forma pela qual o delito é praticado, será possível o reconhecimento do conatus (tentativa)". ${ }^{37}$

Damásio de Jesus, por sua vez, afirma que a "tentativa é admissível na hipótese de apropriação indébita propriamente dita. Ex.: o sujeito é surpreendido no ato de vender a coisa de que tinha a posse ou a detenção" e que “é impossível tentativa de apropriação indébita no caso de negativa de restituição. Ou o sujeito se nega a devolver o objeto material, e o delito está consumado, ou isso não ocorre, não havendo conduta típica". ${ }^{38}$

Para Capez, por seu turno, "controverte-se a doutrina acerca da possibilidade da tentativa do crime de apropriação indébita". Para o autor, esta é possível, em tese, "no caso de apropriação indébita propriamente dita”, já que se

\footnotetext{
${ }^{36}$ Bittencourt ressalta que Hungria criticava duramente a corrente contrária à admissibilidade da tentativa, citando passagem utilizada também aqui. Veja-se BITENCOURT, Cezar Roberto, op. cit., p. 200.

${ }^{37}$ GRECO, Rogério, op. cit., p. 221.

${ }^{38}$ JESUS, Damásio Evangelista de, op. cit., pp 415-416.
} 
trata de crime material. Ele dá como exemplo a situação do agente que é impedido de vender um objeto que detém ou tem a posse, rejeitando porém a possibilidade do conatus na hipótese de negativa de restituição. Capez complementa: "A possibilidade da ocorrência da tentativa na apropriação é tema que provoca dissidências doutrinárias, em face das peculiaridades do crime, com destaque para o seu elemento subjetivo. De fato, é extremamente difícil fixar o momento em que se apresenta o elemento subjetivo transformador da posse, de alheia para própria (animus rem sibi habendi)", ${ }^{39}$

Nucci, por fim, limita-se a afirmar que a tentativa "é admissível na forma plurissubsistente". ${ }^{40}$

Em suma: no mais das vezes, reproduz-se o pensamento de Hungria ou, mais frequentemente ainda, apenas suas consequências práticas.

Com isso, é de se notar que, ainda que implícita e contraditoriamente, todos os demais autores citados parecem perfilar o mesmo entendimento quando levam à prática a sua teoria. Embora afirmem, como visto, que a apropriação indébita é crime material, que, portanto, admite tentativa, ao tratar dos casos concretos assumem aquela característica postura de Hungria, de sobrevalorização da verificação do elemento subjetivo na determinação do momento consumativo, o que leva, justamente, à aparente contradição entre o estabelecimento de uma natureza implicitamente formal à estrutura do delito e a afirmação de que este é crime material que, portanto, admite tentativa.

Nota dissonante nesse cenário é o pensamento de Régis Prado, que, de forma explícita e transparente, discute a questão da tentativa e avalia que "aqueles que admitem a tentativa expendem argumentos puramente empíricos, enquanto aqueles que inadmitem o conatus o fazem sobre sólida articulação técnica".

\footnotetext{
${ }^{39}$ CAPEZ, Fernando, op. cit., p. 542

${ }^{40}$ NuCCI, Guilherme de Souza, op. cit., p. 696.
} 
Para esse autor, "a apropriação é crime instantâneo que pressupõe a posse ou detenção pelo sujeito ativo, consumando-se com a exteriorização de sua vontade de não restituir. Isso ocorre mesmo na modalidade omissiva, porque não há separação temporal entre o momento da omissão e o momento da infração". 41

Logo, para Prado, "no exemplo do proprietário que flagra o possuidor no momento em que está vendendo a coisa, sendo impedido de tradicioná-la ao comprador: é até mesmo ilógico pretender-se o reconhecimento do conatus sob o argumento de que nenhum fato anterior evidenciara efetiva apropriação, sendo insofismável a circunstância de que o possuidor está alienando, agindo como se dono fosse, restando consumado o crime ante a inequívoca prova de inversão do título da posse (consciência de que não restituiria a coisa)". 42

Com isso, leva-se, explicitamente, às últimas consequências o pensamento de Hungria segundo o qual o elemento subjetivo, quando exteriorizado, é suficiente à consumação do delito, que ocorreria, imediata e automaticamente, nesse momento. No ponto em que Hungria cedia, para admitir a tentativa, Prado insiste no dever de seguir até o fim, ainda que inconsciente e implicitamente, a lógica do crime formal. ${ }^{43}$

Diante desse quadro, temos que o problema central de compreensão da estrutura típica e da economia do delito persiste de forma importante. A verdade é que nossa doutrina mais recente, em razão da natureza dos manuais em que é veiculada, não aprofundou o debate que poderia ter dado melhor tratamento ao tema. Não é de admirar, então, que nossa jurisprudência

\footnotetext{
${ }^{41}$ PRADO, Luiz Regis, op. cit., p. 476.

${ }^{42}$ Idem. Ibidem.

${ }^{43}$ É interessante notar que, no que diz respeito ao crime de extorsão, fenômeno parecido se produz no cotejo dos pensamentos de Hungria e Prado. Com efeito, ao tratar da consumação do crime de extorsão, Hungria defende que este é crime formal, que, no entanto, admite tentativa de forma ampla. Tal contradição não escapou à critica de Prado, que insiste, também naquele ponto, que o apelo à lógica exigiria o reconhecimento da impossibilidade da tentativa de extorsão no alcance proposto por Hungria. A crítica a tal posicionamento pode ser vista em GOMES JÚNIOR, João Florêncio de Salles, $O$ Crime de Extorsão no Direito Penal Brasileiro, São Paulo, Quartier Latin, 2012.
} 
acabe por claudicar na apreciação do tema da consumação e tentativa de apropriação indébita no Direito Penal brasileiro. Diante das limitações doutrinárias, tampouco houve avanço na jurisprudência.

Em 1954, o Supremo Tribunal Federal já enfrentava a questão da consumação em interessante caso de "viajante-vendedor" que se apropriara indebitamente de joias pertencentes à sua empregadora. ${ }^{44} \mathrm{~A}$ importância do julgamento na fixação da jurisprudência do Supremo Tribunal Federal sobre o tema e a presença do próprio Hungria no debate recomendam especial atenção ao acórdão.

Trata-se de caso em que, ao fazer uma viagem pelo Estado do Paraná, após receber as joias de sua empregadora na capital do Estado de São Paulo, o réu acabou por vender, ao chegar à capital paranaense, grande parte do que the havia sido confiado, empenhando a parte restante, sendo certo que o produto da venda e dos empenhos foi gasto em proveito próprio, não enviando o saldo à empregadora.

O Juízo Criminal da Comarca de São Paulo, ao qual fora denunciado o réu, entendeu por bem declarar-se incompetente, apesar de o Tribunal paulista entender, em diversos casos, ser competente, no caso de apropriação indébita de mercadoria ou dinheiro entregues a viajantes de casas comerciais, o foro da comarca em que deveriam ser prestadas as contas pois somente então ficaria provada a apropriação, com a recusa de entrega do preço de venda. No caso concreto, segundo o Tribunal, haveria outros elementos para fixar o momento da apropriação, consumada no próprio local de venda das joias, pois, por se tratar de mostruário que não lhe fora entregue para ser transacionado, a própria venda já demonstraria de maneira cabal a intenção do réu de se apropriar de objetos que não lhe pertenciam.

${ }^{44}$ STF, Conflito de Jurisdição no 2079/PR, Rel. Orosimbo Nonato. 
O Juízo Criminal de Curitiba, por sua vez, entendeu que, ao contrário do afirmado pelo Juízo da Comarca da Capital do Estado de São Paulo, as joias em questão não formavam um mostruário. Para tanto, destacou a presença de um "despropósito de coisas", entre as quais 41 relógios da mesma marca, cromados e com o mesmo preço unitário, 72 alianças folhadas, 20 dúzias de medalhas. Concluiu que o réu transportava, na verdade, mercadorias, e não apenas um mostruário, e que, portanto, o local de consumação do delito só poderia ser o local onde deveria ser feita a devida prestação de contas, ou seja, a capital paulista.

Suscitado o conflito de jurisdição, decidiu o Supremo Tribunal Federal pela competência do Juízo da Capital do Estado de São Paulo, vencido o ministro Nélson Hungria.

Para o relator, ministro Orosimbo Nonato, se realmente se tratasse de amostras das mercadorias à venda, ocorreria "circunstância especial reveladora do ânimo de se apropriar do objeto alheio" que o levaria a decidir pela competência da Justiça do Paraná. Ocorre que, ainda segundo o relator, haveria sérias dúvidas quanto a se tratar de simples mostruários, o que o levara a concluir pela consumação do crime na Capital do Estado de São Paulo, onde deveriam ser prestadas as contas.

Surge, então, a divergência do ministro Nélson Hungria. Para ele, fiel ao próprio pensamente doutrinário, e forte na ideia de que, apesar da grande quantidade de itens iguais, poder-se-ia concluir pela tese acusatória da existência de meras amostras, o crime teria se consumado na capital paranaense, pois "antes da recusa, antes que fosse exigida a devolução da coisa, já o acusado tinha vendido em Curitiba os objetos confiados para o fim de amostra, isto é, já tinha, iniludivelmente, praticado o abuso de confiança, locupletando-se com o dinheiro de venda de objetos não destinados ao comércio”. 
Com a divergência, impõe-se uma maior explicação do voto do relator e inicia-se o debate propriamente dito. Busca o relator, ministro Orosimbo Nonato, explicar que, embora concorde com o ministro Nelson Hungria quanto ao fato de o crime se consumar no momento de transformação da posse pelo animus domini do apropriante, no caso dos autos, por não se poder concluir se tratar de meras amostras de mercadorias, e sim de objetos destinados à venda, somente "quando se recusou o empregado a entregar o dinheiro foi que surgiu o indébito. Neste momento é que se configura, é que se aperfeiçoa o delito".

Diante da divergência, o ministro Mario Guimarães esforça-se em buscar um ponto de concordância, de forma a viabilizar, crê-se, a própria estabilização da jurisprudência do Supremo Tribunal Federal. Afirma, então, ao que parece de forma equivocada, que "todos estão concordes em que o crime de apropriação indébita se consuma quando se verifica que, por circunstâncias dadas, o agente criminoso se recusa a entregar aquilo de que se apropriou", para depois concluir que "até parece que ele se apropriou foi do dinheiro, e não das mercadorias. Podia tê-las vendido, retendo o dinheiro até voltar a São Paulo, para entregar ao verdadeiro dono. Não o entregou, porém. Aí se consumou o crime”.

A dificuldade fica evidente. Enquanto o ministro Orosimbo Nonato afirma que se deve reputar consumado o crime de apropriação indébita no local destinado à prestação de contas, o ministro Nélson Hungria insiste que o local de venda das mercadorias, por ser aquele onde já se revelou o animus rem sibi habendi é que deveria ser considerado como tal. Por fim, o ministro Mario Guimarães, na tentativa de superar a divergência, faz surgir a concordância formal onde só há divergência real e julga-se o caso concreto, com voto vencido do ministro Nelson Hungria, sem que, na verdade, se tenham explicitado e acordado os critérios de fixação do momento consumativo do delito de apropriação indébita no Direito Penal brasileiro.

Em momento seguinte, no ano de 1956, o Supremo Tribunal Federal volta a enfrentar o tema da consumação. 
Trata-se de caso em que o réu, residente em Mogi das Cruzes, em São Paulo, é encarregado pela vítima, também residente naquela cidade, de receber, em Barra Mansa, no Rio de Janeiro, três vales que lhes eram devidos por uma empresa metalúrgica. $\mathrm{O}$ réu, então, recebe o dinheiro e regressa à cidade de Mogi das Cruzes, onde deveria prestar contas. Como bem sintetizado no acórdão, “de regresso, encontra-se com um empregado da vítima, a quem deu notícia de recebimento, indo ambos almoçar juntos, ficando combinado que após a refeição iriam os dois à presença do lesado, fazer-lhe entrega da importância recebida. Terminada a colação, o réu afastou-se, declarando que iria comprar um maço de cigarros, não mais voltando". 45

A maior simplicidade do caso, porém, facilita a concórdia e entende-se, por unanimidade, presentes, inclusive, os ministros Nelson Hungria e Orosimbo Nonato, que, diante da ausência de qualquer outro indicativo da mencionada apropriação, neste caso o crime de apropriação indébita consumarase no local em que o agente deveria prestar contas dos valores recebidos, fixandose a competência do juízo de Mogi das Cruzes para o processamento do feito.

Mais adiante, em 1976, no Supremo Tribunal Federal, outro interessante caso desperta a atenção, desta vez sobre a possibilidade de tentativa do delito. ${ }^{46}$

Trata-se da apropriação indébita de 30 sacas de café colhidos pelo réu, de nome Waldemar, na propriedade rural da vítima, com quem mantinha parceria, estabelecida verbalmente.

No caso em tela, a vítima notou a falta das mencionadas sacas de café e, após breve investigação, descobriu-as escondidas sob alguns cafeeiros. Levando o fato ao conhecimento da autoridade policial, foi orientada a vigiar o

\footnotetext{
${ }^{45}$ STF, Conflito de Jurisdição no $2186 /$ SP, Rel. Rocha Lagoa.

${ }^{46}$ STF, RHC 54122/PR, Rel. Cordeiro Guerra.
} 
local para surpreender a pessoa ou as pessoas que fossem apanhar as sacas de café. $^{47}$

Foi surpreendido o réu Waldemar, então, pela vítima e seus dois filhos, quando, à noite, após retirar o café que se encontrava sob os cafeeiros, transportava-o para outro local que não o imóvel onde trabalhava na qualidade de parceiro da vitima. Segundo a denúncia, a vitima e seus filhos acabaram por desferir "vários tapas, socos, pontapés, e pauladas" o que, na visão da acusação teria impedido a consumação da apropriação indébita, razão pela qual ofereceu-se denúncia pela tentativa do delito.

Foi denunciado também, pela tentativa do delito, o réu David, empregado de Waldemar, pois teria sido ele a esconder as mencionadas sacas de café sob os cafeeiros, durante o dia, para que, à noite, este fosse apanhá-las.

Buscou, então, a defesa, via habeas corpus, obter a anulação da denúncia sob o argumento de ser inconfigurável a tentativa do delito de apropriação indébita.

Ao apreciar a questão, limitou-se o Supremo Tribunal Federal a afirmar a possibilidade de tentativa do crime de apropriação indébita, sob o argumento de que, se é verdade que o crime é instantâneo, também o é que seja material. Assim, se, iniciada a execução, não se consuma a apropriação por circunstâncias alheias à vontade do agente, verifica-se a tentativa.

Quanto ao caso concreto, destacou-se que, na verdade, se trataria de crime consumado, pois, na lição de Hungria, “o escondimento da coisa é fato revelador do momento consumativo da apropriação indébita" na medida em

\footnotetext{
${ }^{47}$ A denúncia, aliás, tem um aspecto curioso. A orientação da autoridade policial para que a própria vítima efetuasse a prisão e, na sequência, a manutenção dos apropriadores na prisão sem as formalidades legais, fez com que a vítima da apropriação e seus filhos também fossem denunciados (pelas lesões corporais que causaram ao efetuar a prisão), bem como o delegado de polícia (por abuso de autoridade).
} 
que, é importante destacar do acórdão, "o simples fato de haver ocultado trinta sacas de café, revela o dolo com que agia" o réu.

Tais assertivas e a menção quase exclusiva ao pensamento de Hungria, tanto no parecer da Procuradoria da República quanto no próprio acórdão do Supremo Tribunal Federal, parecem selar o compromisso de nossa jurisprudência com o pensamento desse autor e, portanto, como se verá, com as limitações do seu tempo.

O STF consignou apenas que, sendo verdade que o crime seja instantâneo, ele também deve ser necessariamente material. Assim, a própria ausência de melhor desenvolvimento da justificativa para a admissibilidade da tentativa já demonstra uma autolimitação da abrangência e profundidade do raciocínio, o que acaba por inviabilizar o avanço jurisprudencial na busca do melhor critério a ser utilizado. Como se verá adiante, o melhor desenvolvimento conceitual das condições de imediatismo e de materialidade do crime poderia ter levado à superação de alguns dos problemas até hoje enfrentados pela jurisprudência brasileira.

Assim, embora seja correto afirmar que no caso em tela tratarse-ia de crime consumado, razão pela qual de rigor o improvimento do recurso em habeas corpus, o fato é que não se inovou, mais uma vez, na discussão da tentativa de apropriação indébita, limitando-se o tribunal a admiti-la, genericamente, sem lhe traçar os precisos contornos.

Essa generalidade na apreciação da questão da tentativa mais uma vez impede a jurisprudência de suprir a deficiência doutrinária na fixação do momento consumativo do delito e em relação à possibilidade ou impossibilidade de tentativa.

No mesmo sentido, mais recentemente, o Supremo Tribunal Federal limita-se a reproduzir, no tema da consumação, aquela ideia inicial 
segundo a qual o crime de apropriação indébita se consuma no local e no momento em que a prestação de contas deveria se efetivar, quando devida.

Com o que, afirma-se, em determinado caso concreto, que o advogado que levanta valores em nome de uma empresa sua cliente em agência bancária de Belo Horizonte e os deixa de repassar ao cliente em Ribeirão Preto, no interior paulista, onde deveria prestar contas, deve responder pelo crime de apropriação indébita nesta cidade do interior paulista, onde se reputa consumado o delito. $^{48}$

Em outro acórdão, decide-se que, para fins de cálculo prescricional no caso concreto, o crime de apropriação indébita praticado por advogada que, tendo recebido valores levantados mediante alvarás judiciais em inventário, deixou de repassá-los a quem de direito, deve ser considerado consumado no dia em que findou o prazo de quinze dias que lhe fora dado para a prestação de contas e devolução dos valores.

Com isso, seja pela escassez de casos que são submetidos ao Supremo Tribunal Federal, seja pela falta de subsídios doutrinários a amparar as suas decisões, esgota-se, até o momento a possibilidade de se encontrar uma solução mais detalhada e profunda da questão da consumação e tentativa da apropriação indébita na jurisprudência da mais alta corte do país. ${ }^{49}$

\footnotetext{
${ }^{48}$ STF, $1^{\text {a }}$ Turma, HC 87.846-6, Rel. Sepúlveda Pertence, J. 28.03.2006, DJU 19.05.2006.

49 Há, ainda, na jurisprudência do Supremo Tribunal Federal, interessante julgado relacionado à apropriação indébita prevista no Código Penal Militar. Por não se tratar de julgado relacionado ao tema central desse trabalho, qual seja, a questão da consumação e tentativa de apropriação indébita, ele será registrado apenas em nota. Trata-se de caso concreto no qual se discute a subsunção da apropriação indébita praticada por civil, em tempo de paz, à figura típica prevista no artigo 248 do Código Penal Militar. Segundo o acórdão, o acusado, na condição de funcionário da Capelania castrense, teria se apropriado de dinheiro recolhido dos fiéis, destinados à Igreja. Concluiu o Supremo Tribunal Federal, em apertada síntese, que não há que se falar em atipicidade da conduta, na medida em que, a Capelania Católica, "embora subordinada exclusivamente ao Arcebispo Militar no que diz respeito aos aspectos canônicos/religiosos, subordina-se ao Comandante da Organização Militar onde está inserida", o que justificaria a aplicação do Código Penal Militar e a própria competência da Justiça castrense (STF, 2 ${ }^{\mathrm{a}}$ Turma, RHC 96.814-7 PA, Rel. Eros Grau, J. 12/05/2009, DJe $n^{\circ}$ 148, 06/08/2009).
} 
O panorama não é significativamente diferente no Superior Tribunal de Justiça.

Em curioso caso no qual o réu pediu emprestado para um amigo, em Curitiba, o seu automóvel, modelo "Corvette", dizendo que "ia fazer uma moral numa menina, por umas duas horas" e desapareceu com o carro, vendendo-o posteriormente em São Paulo, decidiu-se que a consumação se dera na capital paulista, e não em Curitiba, onde o carro deveria ter sido devolvido. ${ }^{50}$

Em outro caso envolvendo veículos, o agente tomou emprestado um automóvel, na cidade de Curitiba, para resolver problemas particulares na cidade de Guaraçaí, interior paulista. Lá chegando, tentou entregar o veículo a terceiro, a título de compensação de dívidas, como se de sua propriedade fosse. Entendeu o Superior Tribunal de Justiça que o local de consumação do crime seria a cidade de Guaraçaí, onde o agente "transformou a posse em propriedade, em que externou sua vontade de não restituir o bem que estava em sua posse em razão do empréstimo". ${ }^{51}$

Estabelece-se, assim, como está claro, tão somente um parâmetro para a fixação do momento consumativo da apropriação indébita de veículos automotores, posteriormente colocados à venda, baseado, sobretudo e mais uma vez, na exteriorização da vontade de se apropriar do bem em questão ou, em outras palavras, de inversão do ânimo da posse.

Nota-se aqui, como sempre, a percepção da conduta como mera manifestação do elemento subjetivo, que acaba se tornando o critério central de resolução da questão da consumação. Limita-se sobremaneira a discussão, não só quando se utiliza tal raciocínio para fixar a competência, mas também quando sequer se cogita a possibilidade de se estar diante de tentativa do delito, na

\footnotetext{
${ }^{50}$ STJ, 3 a Seção, CC 16.389/SP, Rel. Edson Vidigal, J. 26.06.1996, DJU 21.10.1996. No mesmo sentido: STJ, CC 1.646/MG, Rel. Flaquer Scartezzini, DJU 03.06.1991; STJ, CC 255/PE, Rel. Dias Trindade, DJU 25.09.1989.

${ }^{51}$ STJ, $3^{\text {a }}$ Seção, CC 102.103/PR, Rel. Maria Thereza de Assis Moura, J. 12.08.2009.
} 
medida em que o agente somente tentou entregar o veículo ao terceiro, que não o aceitou, por saber não se tratar de "homem de palavra".

No mais, limita-se o Superior Tribunal de Justiça a também fixar parâmetros para aferição da consumação nos casos em que é necessária alguma prestação de contas.

Dessa forma, ao apreciar o caso de um advogado que levantara valores em agência bancária de uma cidade para prestação de contas em outra ${ }^{52} \mathrm{e}$ o caso de um engenheiro que era incumbido de transportar valores entre o canteiro de obras em Pernambuco e a sede da empresa em São Paulo ${ }^{53}$, entendeu o Superior Tribunal de Justiça que, diante da ausência de qualquer outro ato revelador da apropriação indébita, esta deveria se reputar praticada nas cidades onde se deveria prestar contas dos valores recebidos, nelas fixando-se, por consequência, a competência para os respectivos julgamentos.

\subsection{Colocação do problema: Estrutura típica e economia do delito de apropriação indébita no Direito Penal brasileiro.}

Vê-se, portanto, que nossa doutrina e jurisprudência dominantes sobre a consumação e a tentativa do crime de apropriação indébita, tal como expostas até o momento, parecem não perceber as contradições que se impuseram, o que acaba por gerar insegurança jurídica e, por que não dizê-lo, injustiça.

Com efeito, ao enxergar o ato de apropriação essencialmente como mera revelação do animus rem sibi abendi, suficiente à fixação do momento consumativo do crime, acaba-se por atribuir, inconscientemente,

\footnotetext{
${ }^{52}$ STJ, $66^{\mathrm{a}}$ Turma, HC 73.352/SP, Rel. Carlos Fernando Mathias, J. 29.11.2007, DJe 26.05.2008.

${ }^{53}$ STJ, $3{ }^{\text {a }}$ Sessão, CC 355/PE, Rel. Dias Trindade, J. 31.08.1989, DJU 25.09.1989.
} 
natureza formal ao delito de apropriação indébita, em que pese a afirmação, unânime, de se tratar de crime material. Tal situação, por evidente, não pode deixar de conduzir às contradições doutrinárias já apontadas e, por derradeiro, à própria incompreensão da estrutura típica real da apropriação indébita. A aparente inconsciência de que tais contradições, referentes à consumação e tentativa de apropriação indébita, derivam do mencionado equívoco sobre a necessidade de afirmação concreta da natureza material do delito, parece inviabilizar que nossa doutrina, por seus próprios fundamentos, possa sair do labirinto em que se encontra.

Desnecessário dizer que tal incompreensão ainda pode gerar, se não se admite a tentativa ou se não se compreende o seu alcance, situações de evidente desproporcionalidade, com a imposição de pena destinada ao crime consumado às situações nas quais, claramente, não há resultado típico a atingir a propriedade.

Tal situação acaba obrigando vários autores a se contradizerem e, por amor à justiça, para admitir a tentativa, denominarem e tratarem como crime material o que antes descreveram, em realidade, como crime formal. Enquanto isso, outros, por amor à técnica, acabam aceitando a situação que se mostra de todo injusta de imposição de pena por crime consumado a condutas que não geram qualquer lesão ao bem jurídico protegido pelo tipo penal.

Nesse contexto, a uniformidade de nossa jurisprudência, mais do que revelar a solução do problema dado, no caso o da consumação e tentativa do crime de apropriação indébita, bem representa a inconsciência do problema de fundo e a relativa superficialidade no enfrentamento da questão, com vistas apenas à solução - eminentemente casuística — do caso concreto.

Ao não se dar conta da existência e importância de tal contradição entre o discurso formal e o verdadeiro significado emprestado à estrutura típica do crime de apropriação indébita, mesmo os autores do mais alto 
nível no Direito brasileiro acabam limitados em suas tentativas de melhor compreender o tipo penal de apropriação indébita.

Nesse ponto, é preciso ressaltar que ao menos um autor de fundamental importância para o Direito Penal brasileiro esteve próximo de compreender o equívoco de Hungria e superar sua contradição.

Para Edgard Magalhães Noronha, "nem sempre é fácil determinar o momento consumativo da apropriação indébita. Pela estrutura que ela oferece, a consumação exige detido exame do elemento subjetivo, que se há de revelar num ato exterior, para que incida na sanção legal. A apreciação deste é, pois, inseparável da análise do elemento subjetivo". 54

Note-se que, embora se reconheça no pensamento de Noronha o apego à necessária análise do elemento subjetivo, este não domina toda a cena, destacando o autor, desde logo, que sem ato exterior do agente não há que se falar no crime.

A diferença pode parecer sutil, mas é substancial. Ao não concentrar seu olhar exclusivamente sobre o elemento subjetivo, compreendendo que este não pode e não deve existir desacompanhado de uma conduta externa, Noronha coloca o problema de forma compatível com a realidade subjacente ao delito, garantindo maior equilíbrio entre os elementos típicos que compõe sua economia.

Feita essa observação inicial, Noronha adverte que o crime se consuma "com a apropriação e não com o lucro ou proveito do agente ou de terceiro, elemento condizente ao dolo específico. Dá-se a consumação quando a coisa sai do patrimônio do sujeito passivo, e tal pode dizer-se, atendendo-se à natureza do crime, quando o agente transforma sua posse ou detenção em domínio; quando pratica atos inequívocos de dono; quando deixa de possuir a

\footnotetext{
${ }^{54}$ NoronHA, Edgard Magalhães, Direito Penal, São Paulo, Saraiva, 2003. p. 344.
} 
coisa em nome e no interesse de quem lhe transferiu a passa a dispor dela como se dono fosse". 55

Verifica-se aqui, mais uma vez, a característica do pensamento do autor sobre a consumação, que, se melhor desenvolvida pela doutrina mais recente, poderia ter representado a superação do equívoco manifestado por Hungria. Nesse ponto, Noronha claramente vincula a consumação do crime de apropriação indébita a ato externo e, mais do que isso, a ato externo que atinja o patrimônio da vítima. Tal posicionamento parece apontar claramente para a necessidade de verificação concreta de conduta lesiva ao patrimônio — ou à propriedade, quem sabe - para a consumação do crime em questão.

Nesse sentido, o autor afirma que "é a apropriação indébita delito de dano, que se verifica com a consumação, independente do lucro ou proveito do sujeito ativo". Citando Vincenzo Manzini, assevera que "o crime em exame é positivamente de dano e não de mero perigo; mas para constituí-lo é suficiente aquele dano que necessariamente e sempre é inerente ao fato da apropriação. Não se deve confundir este dano necessário e suficiente com aquele dano maior que pode derivar da perda definitiva da coisa por parte do proprietário ou de outras causas semelhantes" para concluir que, "convertida a posse ou detenção em domínio, passando o titular destas a agir como se dono ou proprietário fora, há já diminuição patrimonial para o sujeito, há ofensa ao seu patrimônio", 56

Dessa forma, para Noronha, o crime de apropriação indébita consuma-se no momento da ação típica não porque esta seja tão somente a revelação do animus rem sibi abendi, mas fundamentalmente porque é no momento da ação que a vítima experimentaria o prejuízo patrimonial que a lei pretende evitar. Tal diferença pode parecer pouco significativa, pois o momento consumativo, no mais das vezes, será o mesmo do proposto por Hungria, mas

\footnotetext{
${ }^{55}$ Idem. p. 344

${ }^{56}$ Idem. p. 345.
} 
essa mudança no fundamento da consumação poderia ter representado, se melhor desenvolvida pela nossa doutrina, a correção de rota mais importante na interpretação do tipo penal de apropriação indébita, quer porque melhor garantiria princípios do fundamentais do Direito Penal democrático, como o princípio da lesividade, evitando incriminações indevidas, quer porque retomaria a compreensão da ordem estrutural do delito, com consequências benéficas sobre os diversos pontos em que a interpretação do delito se encontra frágil ou contraditória, especialmente sobre a questão da consumação e tentativa.

É de se notar, no entanto, que apesar de se aproximar muito mais significativamente que Hungria da compreensão da necessidade de lesividade ou de materialidade da conduta típica para a consumação do delito de apropriação indébita, Noronha vê com muitas reservas a possibilidade de tentativa do delito em questão.

Com efeito, ao tratar da questão, afirma Noronha que considera “mui difícil a configuração da tentativa, perante nosso Código. Não tanto assim, à luz do italiano, que pune como tentativa os atos preparatórios". ${ }^{7}$

Isso porque, após apontar as divergências doutrinárias, Noronha entende que "a dificuldade da realização reside em que a apropriação indébita é crime instantâneo e tem como pressuposto material achar-se já a coisa na posse ou detenção do agente. Ora, considerado isso e atendendo-se a que a apropriação (consumação) se realiza por um ato da vontade do agente em relação à coisa, parece-nos problemática a hipótese de se fracionar a figura delituosa, isolando-se a intenção da consumação". 58

É sintomático que Noronha evite fechar questão. Ao limitar-se a apontar as dificuldades de compreensão do fenômeno e sua problemática, Noronha como que intui a contradição em que poderia cair, evitando ir às últimas consequências do seu raciocínio, que resta incompleto.

\footnotetext{
${ }^{57}$ Idem. p. 346.

${ }^{58}$ Idem. Ibidem.
} 
Nesse ponto ocorre, ao que parece, como que um retrocesso no pensamento do autor. Noronha caminhava para uma compreensão integral da estrutura típica, mas não chega a compreendê-la totalmente no que se refere às questões ligadas à necessidade de lesão à propriedade para a consumação do delito. $^{59}$

Fica evidente, portanto, a difícil situação ora enfrentada. Não há ainda em nossa doutrina nenhuma obra voltada precipuamente à melhor compreensão da estrutura típica e da economia do delito de apropriação indébita no Direito Penal brasileiro.

Se realmente há um problema a ser superado, relativo à contradição entre o caráter formal atribuído, de fato, ao tipo penal de apropriação indébita e o discurso jurídico dominante que trata-o como crime material, é de se notar que doutrina e jurisprudência dominantes parecem satisfeitas com o resultado da interpretação até agora realizada, essencialmente casuística e positivista, de todo distante da problemática ora posta em questão.

Assim, não bastassem os prejuízos referentes ao próprio tema da consumação e tentativa já apontados, a distorção na atribuição de papel sobrevalorizado ao elemento subjetivo do tipo acaba por contaminar e, por vezes inviabilizar, a compreensão de toda a conduta, da estrutura do tipo penal e do seu sentido. Tal se dá, por exemplo, quando se pretende compreender a apropriação indébita de uso e sua atipicidade, pois não é possível fazê-lo, como se verá, sem a compreensão de que há um determinado resultado típico a ser alcançado pela conduta de apropriação indébita, que, se não buscado pelo agente, que apenas visava usar o bem que se encontrava em sua posse, pode levar à atipicidade da conduta.

\footnotetext{
${ }^{59}$ Não se pode perder de vista, aliás, sob pena de anacronismo, que os avanços doutrinários ocorridos desde então nos permitem ver com maior clareza a questão, não sendo correto exigir de NORONHA, Edgard Magalhães, Direito Penal, São Paulo, Saraiva, 2003, uma visão sobre o tema que antevisse desenvolvimentos doutrinários posteriores ao seu tempo. O que denominamos seu retrocesso não se trata de censura pura e simples, mas de compreender as limitações enfrentadas pelo autor e de tentar dar desenvolvimento ao raciocínio que este começou a empreender.
} 
É então de fundamental importância retomar - ou mesmo iniciar - o debate sobre a estrutura típica e a economia do delito de apropriação indébita no Direito Penal brasileiro.

O estudo do crime de apropriação indébita no Direito Penal brasileiro deve ser, antes de tudo, o estudo de sua consumação e da tentativa. Somente com a revelação de sua verdadeira estrutura típica será possível desfazer a contradição e a desordem que ora se apresentam, de forma a melhor garantir a segurança jurídica. Tal desiderato pode ser alcançado, como se pretende demonstrar, pela reanálise do tipo penal sob o enfoque de um método estrutural que evidencie sua natureza e sentido. Somente após o desfazimento do nó, objeto do presente trabalho, é que a doutrina sobre os demais aspectos do crime de apropriação indébita poderá se desenvolver de forma mais ordenada.

Em suma: urge buscar uma nova forma de compreender a estrutura típica e a economia do delito de apropriação indébita, de forma a poder avançar nos pontos em que, por motivos os mais relevantes, nossa doutrina ainda não foi capaz de avançar. Essa forma, ficará claro, passa pela utilização de um determinado método estrutural que, aliado à correta ponderação da questão do bem jurídico protegido, é capaz de desvelar e resolver o problema proposto. 


\subsection{O método estrutural ${ }^{60}$}

O desejo de ordem tem acompanhado o homem em toda a sua história. Na própria descrição da criação do mundo, tal como nos é revelada pela tradição judaico-cristã, verifica-se uma verdadeira sinfonia da criação, cuja harmonia se dá pela correta disposição das coisas, cada uma em seu lugar. ${ }^{61}$

Não é de se admirar, portanto, que, de acordo com Miguel Reale, “o reconhecimento dos valores da 'ordem' e da 'segurança' como pressupostos inamovíveis da experiência jurídica prende-se à tradição do Direito, desde os filósofos gregos e os jurisconsultos romanos até nossos dias. ${ }^{" 62} \mathrm{Na}$ verdade, como ensina o catedrático franciscano, "a ideia de justiça liga-se intimamente à ideia de ordem. No próprio conceito de justiça é inerente uma ordem, que não pode deixar de ser reconhecida como valor mais urgente, o que está na raiz da escala axiológica, mas é degrau indispensável a qualquer aperfeiçoamento ético." 63

No Direito Penal, essa necessidade de segurança se faz sentir de forma peculiar, na medida em que é preciso proteger o cidadão do arbítrio do

\footnotetext{
${ }^{60}$ Várias considerações introdutórias e metodológicas constantes do presente capítulo representam parcela importante do pensamento do autor sobre os fundamentos que devem reger a análise dos tipos penais. Dessa forma, também se encontram presentes no capítulo introdutório de sua dissertação de mestrado, publicada como GOMES JúNIOR, João Florêncio de Salles, O Crime de Extorsão no Direito Penal Brasileiro, São Paulo, Quartier Latin, 2012.

${ }^{61}$ Cf. Livro do Gênesis. Não por acaso São Paulo aconselha aos cristãos que "tudo se faça de maneira decente e ordenada".

62 REALE, Miguel, Filosofia do Direito, São Paulo, Saraiva, 2002. p.595.

${ }^{63}$ Idem. p.594
} 
Estado no exercício do direito de punir, sob pena de instauração de um verdadeiro regime de terror, de todo incompatível com a dignidade da pessoa humana. ${ }^{64}$

Na obra de Beccaria, por exemplo, já se percebe, de forma absolutamente clara, a preocupação com essa questão, quando este verifica, criticamente, "a sorte de um cidadão mudar várias vezes, ao passar por diversos tribunais" e "a vida dos miseráveis ser vítima de falsos raciocínios ou do atual fermento dos humores de um juiz." 65

Desde então, diversas conquistas relacionadas à segurança jurídica no campo penal, como, por exemplo, a consolidação histórica do Princípio da Legalidade ${ }^{66}$ e o desenvolvimento dogmático ocorrido especialmente a partir de escola técnico-jurídica ${ }^{67}$ permitiram um grande desenvolvimento dos mecanismos de garantia do cidadão contra o arbítrio e a opressão.

No entanto, hoje passos mais largos se tornam obrigatórios.

O problema da insegurança jurídica continua a se impor ao observador atento da nossa realidade social. À persistente questão da arbitrariedade judicial, veio se somar uma inflação legislativa sem precedentes,

\footnotetext{
${ }^{64}$ Zaffaroni, Eugênio Raúl, PIERAngeli, José Henrique, Manual de Direito Penal Brasileiro, São Paulo, Revista dos Tribunais, 2001. p.94. Os autores desenvolvem esse aspecto da segurança jurídica através de um interessante exemplo: ao perguntar o que sentiriam os integrantes da comunidade jurídica brasileira se fosse amputada uma mão de um batedor de carteira ou se alguém que falsificasse um passe de metrô fosse condenado a morte, os autores procuram demonstrar que a imposição de uma ordem, para assegurar segurança jurídica, deve se impor também e fundamentalmente como limite ao poder de punir do Estado.

${ }^{65}$ Beccaria, Cesare Marchesi di, Dos Delitos e das Penas, São Paulo, Revista dos Tribunais, 1999. Ver, ainda, CÂMARA, Guilherme Costa, Beccaria e o Pensamento Jurídico-Criminal, in Revista Brasileira de Ciências Criminais, São Paulo, Revista dos Tribunais, jul-set, 2003.

${ }^{66}$ BAtista, Nilo, Introdução Crítica ao Direito Penal Brasileiro, $10^{\mathrm{a}}$ ed., Rio de Janeiro, Revan, 2005. p.67. Batista afirma que "o princípio da legalidade, base estrutural de direito, é também a pedra angular de todo Direito Penal que aspire à segurança jurídica, compreendida não apenas na acepção da 'previsibilidade da intervenção do poder punitivo do estado', que lhe confere Roxin, mas também na perspectiva subjetiva do 'sentimento de segurança jurídica' que postula Zaffaroni”. Ver também: Reale Junior, Miguel, Teoria do Delito, $2^{\mathrm{a}}$ ed., São Paulo, Revista dos Tribunais, 2000. p.163 e ss; VAssal, Giuliano, Novíssimo Digesto Italiano, Torino, UTET, 1995. p.493 e ss.; e ToleDo, Francisco de Assis, Princípios Básicos de Direito Penal, São Paulo, Saraiva, 1994.

${ }^{67}$ Cf. FIORE, Carlo, I Presuposti Culturali e Istituzionali del Diritto Penale Vigente, Torino, UTET, 1993; SpIRITo, Ugo, Storia del Diritto Penale Italiano, Torino, Fratelli Bocca, 1932; e SÁINZ Cantero, José A., La Ciencia del Derecho Penal y su Evolución, Barcelona, Bosch, 1970.
} 
dominada pela manipulação midiática da opinião pública, com evidente amesquinhamento das relações políticas. ${ }^{68}$ Por outro lado, o frequente abandono da razão como critério de resolução dos problemas jurídicos concretos, em favor da mera imposição da solução ideológica que, de forma absolutamente subjetiva e casuística, se julga mais justa, certamente não tem colaborado para a formação de uma verdadeira jurisprudência. ${ }^{69}$

Enormes são as contradições presentes no campo criminal tanto na dogmática como na elaboração das leis e em sua própria aplicação. ${ }^{70}$ Temas como segurança jurídica ou garantias positivadas são amplamente questionados, buscando-se mais do que o proposto no dilema de Radbruch. Assim, apesar de continuar correta a afirmativa de que a legislação penal se estruturou como uma forma de limitar o poder punitivo do Estado, configurando o que se conhece por Princípio da Legalidade, ${ }^{71}$ hoje sua própria dimensão e significado devem ser melhor compreendidos.

Pode o Princípio da Legalidade ser considerado um pilar fundamental do Direito Penal em um Estado de Direito, mas, todavia, ${ }^{72}$ esse limite deve ser visto apenas como um marco mínimo de incidência penal. Seria, pois, o marco inicial a partir do qual o Direito Penal pode, ou não, atuar. Não se trata, como pode parecer à óptica estritamente positivista, que, uma vez traçada a previsão legal incriminadora, obrigatoriamente deva haver uma irrefletida atuação penal, de forma a maximizar o seu âmbito de incidência.

\footnotetext{
${ }^{68}$ Cf. MJ. Diagnóstico Preliminar do Sistema Penal Brasileiro e Primeiras Propostas para sua Reformulação da Comissão de Reforma do Sistema Penal Instituída pela Portaria do Ministro da Justiça, no $531,29.09 .1999$.

${ }^{69}$ Cf. Reale Júnior, Miguel, Revista Ciências Penais, São Paulo, Revista dos Tribunais, 2004.

${ }^{70}$ Cf. Robles Planas, Ricardo, Dogmática de los Limites al Derecho Penal, in HiRSCH, Andrew Von, Seelmann, Kurt, Wohlers, Wolfgang, Robles Planas, Ricardo (ed.), Limites al Derecho Penal - Principios Operativos en la Fundamentación del Castigo, Barcelona, Atelier, 2012. pp. 19 e ss.

${ }^{71}$ Cf. Manuel Rojas, Ricardo, Las Contradicciones del Derecho Penal, Buenos Aires, Ad-Hoc, 2000. pp. 73 e ss.

72 PotT, Christine, La Perdida e Contenido del Principio de Legalidad y su Manifestación en la Relación entre el Delito de Encubrimiento por Funcionario (\$258.a StGB) y el Sobreseimiento (\$153 sigs. StPO), trad. Elena Iñigo Corroza y Gillermo Benlloch Petit, in La Insostenible Situación del Derecho Penal, Granada, Comares, 2000. pp. 79 e ss.
} 
$\mathrm{O}$ que antes se mostrou como um marco de garantias muitas vezes se evidencia como a injustiça legal. Determinadas posições e leituras jurisprudenciais, mundo afora, e também no Brasil, mostram-se partidárias, ${ }^{73} \mathrm{e}$ muitas vezes sectárias, consoante seja o crime. Existe, como se pretenderá demonstrar, certa distorção na leitura de crimes patrimoniais e, em especial, do crime de apropriação indébita. Essa leitura enviesada, focada justamente em um positivismo exacerbado, parece hoje fora de esquadro e razão e impede a correta compreensão do delito em questão.

É necessário, portanto, à luz do atual desenvolvimento do Direito Penal, inferir a natureza e o sentido do delito de apropriação indébita e estabelecer, de maneira mais precisa, a relação entre seus elementos objetivos e subjetivos e evidenciar, por meio da compreensão de sua estrutura típica, a exata forma de funcionamento da economia do delito.

Essa tarefa mostra-se viável especialmente quando se utiliza o método estrutural proposto e utilizado por Miguel Reale Júnior, de forma a evidenciar as relações existentes entre os elementos típicos e sua realidade subjacente.

De um lado, a compreensão de que o crime constitui uma realidade unitária e indecomponível impõe-se como um dado inquestionável derivado da própria natureza das coisas. De outro lado, não se pode negar a necessidade científica, especialmente reconhecida a partir da escola técnicojurídica, de decompor a conduta criminosa em elementos típicos para entendê-la em todos os seus aspectos, com profundidade e de forma ordenada.

Nesse sentido, Karl Engisch destaca que "uma primeira e mais complicada tarefa de que o jurista tem de se desempenhar para obter a partir da lei a premissa maior jurídica consiste em reconduzir a um todo unitário os

\footnotetext{
${ }^{73}$ FABricius, Dirk, Posición Político-Partidarista y Capacidad de Comprensión en la Ciencia Jurídico-Criminal - Consideraciones Desde una Perspectiva Etno-Psicoanalítica, trad. Percy García Cavero, in La Insostenible Situación del Derecho Penal, Granada, Comares, 2000. pp. 359 e ss.
} 
elementos ou partes de um pensamento jurídico-normativo completo que, por razões 'técnicas' se encontram dispersas, por que não dizer, violentamente separadas. ${ }^{, 74}$

Para compreender essa questão é preciso notar, com Reale Júnior, que "o legislador constrói os modelos jurídicos, a partir da realidade que vem a recortar, elevando ao plano abstrato ações que constituem um todo indecomponível, cujas partes se inter-relacionam e se polarizam em torno de um sentido, de um valor, que se apresenta negado pela ação delituosa."75

Dessa forma, "cabe ao legislador examinar os dados empíricos que já possuem uma ordem e um sentido intrínseco, objetivando e racionalizando a tipicidade imanente, construindo-a abstratamente e ajuizando-a com base em um valor que se coloca como um fim a ser alcançado." ${ }^{, 76}$

Por consequência, "o tipo penal como estrutura não é uma construção arbitrária, livre, mas decorrente do real, submetido a uma valoração. $O$ real tem uma ordem imanente, resta captar as relações entre os pontos componentes desse compositum, definido qual seja o invariável elementar."77

O pressuposto fundamental desse método é que na construção do tipo penal, segundo Reale Júnior, “o legislador capta a estrutura típica da conduta concreta, apreende seu sentido e o submete a um enfoque valorativo." 78

Dessa maneira, a ação, compreendida em sua realidade, será a âncora do sistema de que fala Miguel Reale Júnior: compreender o sentido e a estrutura típica da conduta e a valoração efetuada pelo legislador são as chaves para a correta interpretação de determinado tipo penal, que, ancorado na sua

\footnotetext{
${ }^{74}$ ENGISCH, Karl, Introdução ao Pensamento Jurídico, Lisboa, Calouste Gulbenkian, 2001. p.116.

${ }^{75}$ REALE JúNIOR, Miguel, Instituições de Direito Penal, Rio de Janeiro, Forense, 2002. p.135 e ss.

${ }^{76}$ Idem. Ibidem.

${ }^{77}$ Idem. Ibidem.

${ }^{78}$ Idem. Ibidem.
} 
realidade imanente, poderá sofrer a influência dos fatores históricos e sociais em sua interpretação sem levar à insegurança jurídica. 


\title{
2 CONDUTA TÍPICA
}

\author{
SUMÁRIO: 2.1 A formação histórica do tipo \\ penal de apropriação indébita 2.2 A posse ou \\ detenção da coisa alheia móvel $2.3 \mathrm{O}$ animus \\ rem sibi habendi 2.4 Conduta típica de \\ apropriação indébita e suas modalidades.
}

O método estrutural de compreensão do tipo penal nos impõe uma primeira tarefa de fixação do invariável elementar do crime de extorsão, por meio da captação e compreensão dos seus elementos típicos fundamentais, tal como se manifestam na realidade.

Como afirma Reale Júnior, “com a fixação do invariável elementar tem-se o perfil do objeto, a conformidade por trás da diversidade, de modo a se construir um modelo pelos traços fundamentais de um comportamento, 
cabendo ao observador estabelecer as regularidades e os encadeamentos envoltos em uma ordem uniforme."

Por essa razão, iniciaremos o estudo do crime de apropriação no Direito Penal brasileiro com a análise dos seus três elementos típicos fundamentais, consistentes na pressuposta posse ou detenção da coisa alheia móvel, o animus rem sibi habendi e a conduta de apropriação propriamente dita, em suas várias modalidades.

\subsection{A formação histórica do tipo penal de apropriação indébita.}

Para tanto convém efetuar uma breve resenha histórica, reveladora da natureza e significado dos elementos típicos fundamentais do crime de apropriação indébita.

No direito romano, não havia a figura da apropriação indébita. Segundo Hungria, “o direito romano desconheceu até mesmo a distinção que por influência do direito germânico, veio a fazer-se entre furtum proprium (mediante contrectio rei) e furtum improprium (em que invés da contrectatio), havia um abuso de precedente posse legítima ou emprego de fraude para a captação do alheio), compreensivo da apropriação indébita e do estelionato, que só mais tarde vieram a constituir entidades criminais autônomas, destacando-se do furto" ${ }^{\text {" }}$.

Para Angelotti, fazendo-se o percurso histórico pelo qual passou a apropriação indébita até tornar-se um delito autônomo, pode-se

\footnotetext{
${ }^{79}$ REALE JúNIOR, Miguel, Instituições de Direito Penal, Rio de Janeiro, Forense, 2002. p.136.

${ }^{80}$ HUNGRIA, Nélson. Comentários ao Código Penal, Volume VII, $2^{\mathrm{a}}$ edição, Rio de Janeiro: Revista Forense, 1958, p.126.
} 
identificar os seguintes períodos: o delito de apropriação indébita é equiparado ao furtum; a apropriação indébita como furtum impróprio, na primeira forma de separação do furtum próprio; a apropriação indébita é assemelhada ao estelionato; e na última fase da evolução legislativa do delito de apropriação indébita como figura autônoma ${ }^{81}$.

Da fase em que o delito de apropriação indébita era equiparado ao furto, o mesmo autor chega a citar como o testemunho legislativo mais antigo o Código de Hamurabi, quando este refere sobre a coisa achada, sob o nome de furto. Igualmente no Código Manu, principal fonte da legislação indiana, se considerava réu de furto aquele que se apropriava de coisa havida em depósito. Portanto, as mais remotas legislações não contemplavam a apropriação indébita como figura autônoma, entrando esta na categoria de furto.

Ainda desta fase, para o autor, diferentemente do que pensa Hungria, está o direito romano. Segundo Angelotti, "o certo era que a jurisprudência romana reconhecia o furto de posse e de uso e que depois em relação à diversidade do objeto distinguiu-se três espécies de furto: furto de coisa, de posse, de uso; na compilação Justiniana encontramos expresso referimento a estas formas, embora não encontremos na fonte as expressões furtum rei, furtum possessonis, furtum usus. ${ }^{" 8283}$.

\footnotetext{
${ }^{81}$ ANGELotTI, Dante, Le Appropriazioni Indebite, $2^{\mathrm{a}}$ edizione, Milano, Società Editrice Libraria, 1933. p. 22.

${ }^{82}$ Idem. p. 25. "Comunque é certo che la giurisprudenza romana riconobbe il furto di possesso e di uso (2) e di qui poi in rapporto alla diversità dell'ogeto la distinzione di tre specie di furto: furto di cosa, di possesso, di uso; cui alla fine compilazioni Giustinianee troviamo espresso riferimento, sebbene non s'incontrino nelle fonti espressioni furtum rei, furtum possessionis, furtum usu" (tradução nossa).

${ }^{83}$ Diferente é o pensamento de Conde-Pumpido: “Assim, pois, não se pode dizer que no direito Romano se chegou a produzir um conceito específico de apropriação indébita, nem sequer que houve uma distinção entre os apoderamentos de coisas possuídas por outros e as apropriações de coisas alheias que estavam em posse do apropriante, misturando-se os distintos como modalidades de furto, ou de fraude, mas sem nunca alcançar uma caracterização própria. "Así, pues, no puede decirse que en el derecho Romano se llegara a producir un concepto específico de la apropiación indebida, ni siquiera que hubiera una distinción entre los apoderamientos de cosas poseídas por otros y las apropiaciones de cosas ajenas que estaban en posesión del apropiante, entremezclándose los distintos supuestos como modalidades de hurto o de fraude, pero sin alcanzar nunca una caracterización propia." CONDEPUMPIDO, Cándido Ferreiro, Apropriaciones Indebidas, Valencia, Tirant lo Blanch, 1997. p.15.
} 
De acordo com Conde-Pumpido, "é na época medieval quando começa a formular-se uma diferenciação [mais clara] com base na distinção entre furtum proprium e furtum impróprio. $\mathrm{O}$ fundamento dessa distinção se encontrava na ideia da violação da posse: se a coisa subtraída e apropriada estava em posse de outro, tal posse era violada e produzia um furto próprio, se a coisa estava já em posse do que dela se apropriava, não havia lesão a posse, pois o agente já possuía a coisa: o furto era, portanto, impróprio. Neste tipo de furto impróprio se incluem a maior parte das hipóteses que hoje constituem apropriação indébita" ${ }^{84}$

Assim, segundo Angelotti, é sobre a noção de furtum proprium e de furtum impropium, que ocorre a separação da apropriação indébita do furto. O delito de apropriação indébita foi surgir como figura jurídica autônoma, na reforma legislativa da Revolução Francesa, com a lei de $1791^{85}$. Nesta lei, surge a apropriação indébita independente do furto, e com pena própria. E, no Código Penal napoleônico também aparece autônoma, sob a denominação, que ainda conserva a reforma do último Código Penal francês, de abuso de confiança". ${ }^{86}$

É, portanto, "a partir desse momento que a tendência da autonomia dessa figura ganha força e Carrara a define como "a dolosa apropriação de uma coisa alheia entregue por seu dono por um título traslativo do

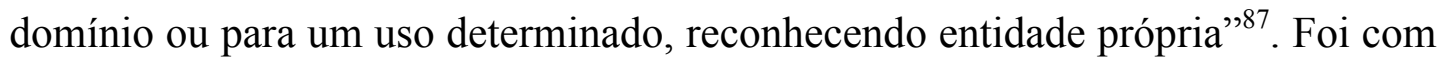
o Código sardo que surgiu a denominação appropriazione indebita, que, como

\footnotetext{
${ }^{84}$ CONDE-PumPIDO, Cándido Ferreiro, p. 15: "Es en la época Medieval cuando comienza a formularse un atisbo de diferenciación en base a la distinción entre furtum proprium y furtum impropium. El fundamento de esa distinción se encontraba en la idea de la «violación de la posesión»: si la cosa sustraída y apropiada estaba en posesión de otro, tal posesión era violada y se producía un hurto propio, si la cosa estaba ya en posesión del que se la apropiaba, no había lesión de la posesión, pues el agente ya poseía la cosa por otro concepto: el hurto era por:tal razón impropio. En este tipo de furtum impropium se incluían la mayor parte de las hipótesis que hoy constituyen apropiación indebida".

${ }^{85}$ ANGELOTTI, Dante, op. cit., p. 31: "I delliti di appropriazione indebita raggiunsero figura giuridica autonoma nella riforma legislative della Rivoluzione francese. Fu con la legge de 29 settembre -6 ottobre 1791 che per la prima volta, sulla nozione del furtum proprium e del furtum improprium, si distinsero I delitti di appropriazione indebita dal furto."

86 Conde-Pumpido, Cándido Ferreiro, op. cit., p.17: "La ley de 29 de septiembre de L791 independiza a la apropiación indebida del hurto y le señala una pena propia. Y el Código Penal napoleónico (art. 408) la configura como tipo autónomo bajo la denominación, que aún conserva la última reforma del Código penal francés, de «abuso de confianza»."

${ }^{87}$ Idem, p.17: "A partir de ese momento la tendencia a la autonomía de esa figura delictiva cobra fuerza y CARRARA la define como «la dolosa apropiación de una cosa ajena entregada por el dueño por un título no traslativo del dominio o para un uso determinado», reconociéndole entidad propia".
} 
visto, já ostentava, em seu período de conformação histórica, a caracterísitca distintiva relacionada a preexistente posse lícita da coisa por parte do sujeito ativo do delito.

\subsection{A posse ou detenção da coisa alheia móvel.}

O pressuposto fático para a configuração do crime de apropriação indébita consiste, portanto, na preexistência da posse ou detenção lícitas da coisa pelo agente. Inexistindo de fato esta condição, não poderá subsistir o delito de apropriação indébita.

No âmbito civil, a posse ou detenção encontram sua definição nos artigos 1196 e 1197 do Código Civil Brasileiro.

Embora o conceito de posse não seja pacífico no campo do direito privado, pode-se afirmar que a doutrina adotada pelo Código Civil Brasileiro de 2002, manteve-se na linha adotada pelo de 1916, ao bem encampar a teoria de Ihering, segundo a qual, em linhas gerais, a posse é a relação de fato estabelecida entre a pessoa e a coisa.

De fato, pode-se afirmar que a posse se constitui de dois elementos: uma coisa, e uma vontade exercida sobre esta coisa. Inexistindo qualquer destes dois elementos inexistirá posse. As divergências na teoria da posse surgem, então, quanto à sua caracterização. Diante da existência no direito privado de duas grandes teoria da posse, necessário se faz analisarmos brevemente cada uma delas. No esforço de interpretação do conceito de posse, Savigny e Ihering, desenvolveram as teorias subjetiva e objetiva da posse que modernamente são utilizadas nos diversos ordenamentos jurídicos. 
De acordo com Orlando Gomes, "a obra de Savigny é uma tentativa de reconstrução sistemática da elaboração da posse do Direito Romano. Para ele, a posse resulta da conjunção de dois elementos; o corpus e o animus. O corpus é o elemento material que traduz no poder físico da pessoa sobre a coisa. O animus, o elemento intelectual, representa a vontade de ter essa coisa como sua". Assim, inexistindo a vontade de ter a coisa como própria, haverá simples detenção. ${ }^{88}$

Dessa definição, verifica-se a existência de dois elementos constitutivos da posse, o corpus, e o animus: aquele é o poder de fato sobre a coisa, que pressupõe a apreensão, que é a exteriorização da relação entre pessoa e coisa; este é a vontade de ter a coisa como própria (animus domini). Uma das críticas dirigidas à teoria de Savigny, fundamenta-se no fato de ser a teoria excessivamente subjetivista, isto é, faz depender a posse de um estado íntimo difícil de ser precisado concretamente ${ }^{89}$.

Ihering opõe-se a este conceito de posse que se baseia fundamentalmente no elemento subjetivo. Para ele, o corpus é a conduta externa da pessoa com aparência de propriedade; o elemento psíquico, o animus, nesta teoria objetivista, não se situa na intenção de dono, mas tão somente na vontade de proceder como habitualmente procede o proprietário.

De acordo com Moreira Alves, referindo-se ao então Código Civil de 1916, "o que o Código Civil brasileiro acolheu da teoria de Ihering foi a orientação objetiva, por ele propugnada, de que decorrem estes princípios: a noção de posse como aparência de direito; a interdependência de seus elementos objetivo e subjetivo, à maneira da vinculação indissolúvel da idéia à palavra; e a lei como elemento distintivo da posse e da detenção, considerada esta como posse

${ }^{88}$ Gomes, Orlando, Direitos Reais, $21^{\mathrm{a}}$ ed., Rio de Janeiro, Editora Forense, 2012. p. 32.
${ }^{89}$ Idem. p. 33. 
degradada, só existente, por isso mesmo, nos casos expressos em dispositivo legal" $" 90$.

Expondo a teoria de Ihering no que tange à diferenciação entre posse e detenção, Alves afirma que: "tanto a posse quanto a detenção exigem o corpus e o animus, não como elementos independentes, mas sim, indissoluvelmente ligados, nascendo ao mesmo tempo pela incorporação da vontade na relação do sujeito com a coisa, e não podendo existir um sem o outro, pois o corpus está para o animus assim como a palavra está para o pensamento ${ }^{91}$ ". Assim, conforme o autor, diferentemente da teoria de Savigny, que distingue a posse da detenção por haver naquela um animus especial, o animus domini, (daí teoria subjetiva segundo Ihering) que não existe nesta, na teoria de Ihering, a distinção entre essas duas figuras baseia-se num elemento objetivo, qual seja, é um dispositivo legal que determina que certas posses sejam consideradas detenção.

Portanto, é significativa a diferença entre as teorias: na de Savigny, para se saber se há posse ou detenção nas hipóteses de relação entre pessoa e coisa, é preciso verificar se ocorre ou não o animus domini; na de Ihering, silenciando a lei, há sempre posse, pois a ocorrência da detenção pressupõe preceito expresso que retire de certa relação entre pessoa e coisa o caráter possessório, ou seja, a detenção não difere teoricamente da posse, mas é uma exceção legal a esta.

\footnotetext{
${ }^{90}$ Alves, José Carlos Moreira, Posse - 1: Evolução Histórica, $1^{\mathrm{a}}$ ed., Rio de Janeiro, Editora Forense, 1999. p. 370. Como bem esclarece Silvio Rodrigues: O Código Civil adotou a teoria de Ihering - Dilo Clovis Bevilaqua, bem como o confirma todos os escritores brasileiros que cuidaram da matéria. Aliás, isso resulta veemente do art. 1196 do Código Civil, que, caracterizando a pessoa do possuidor, fornece os elementos para extrair-se o conceito legal de posse. Diz o dispositivo: Art. 1196. Considera-se possuidor todo aquele que tem de fato o exercício, pleno ou não, de algum dos poderes inerentes à propriedade. Portanto, se possuidor é aquele que atua em face da coisa como se fosse proprietário, pois exerce algum dos poderes inerente $\mathrm{s}$ ao domínio, a posse, para o codificador, caracteriza-se como exteriorização da propriedade, dentro dos termos da concepção de Ihering. Verdade que nalguns passos, e como veremos, o legislador se deixou arrastar pela doutrina de Savigny, voltando à idéia de apreensão material da coisa (v.n.21, infra). Mas, basicamente, o legislador de 1916 e o de 2002 disciplinaram o instituto da posse, inspirados nas idéias de Ihering" (Rodrigues, Silvio, Direito Civil - Direito das Coisas, vol. 5, $27^{\text {a }}$ ed., São Paulo, Saraiva, 2002. p. 20.)

${ }^{91}$ ALVES, José Carlos Moreira, op. cit., p. 229.
} 
Embora exista uma dificuldade em relação ao conceito de posse, quanto a sua distinção com o fenômeno da detenção, sob a ótica do direito civil brasileiro, ela é inexistente. Conforme o previsto no artigo 1.198 do Código Civil, é detentor aquele que achando-se em relação de dependência para com o outro, conserva a posse em nome deste e em cumprimento de ordens e instruções sua. Pode-se afirmar, inclusive, que o atual Código melhor tratou do tema ao definir a detenção de modo expresso

Desenvolvida brevemente a idéia de posse e detenção no direito privado, cabe desenvolver a discussão da aplicação do conceito de posse do direito privado no crime de apropriação indébita.

De acordo com a lição de Antolisei, adotando-se a teoria, de parte da doutrina, que reconhece que a "posse é uma res facti, um estado de fato e não um direito, daí porque não é concebível uma distinção entre posse segundo o direito penal e posse segundo o direito privado, pois se parte de idêntica origem: isto é, da natureza de fato e não de direito [da posse]" ${ }^{, 92}$. Desse modo, não haveria razão para sustentar-se que a posse não pode ser idêntica tanto para o direito penal quanto para o direito privado.

Para Hungria, "para evitar controvérsia de interpretação, a que poderia dar lugar o emprego exclusivo do vocábulo posse, dado o seu estrito sentido técnico-jurídico, o art. 168 refere-se, alternativamente, a 'posse' e "detenção" "93.

Segundo o autor, com o primeiro termo o dispositivo legal trata da "posse direta", e com o segundo termo a lei trata do poder de fato que não constitui posse, uma vez que quem o exerce ou acha-se em uma relação de dependência para com outro, conservando a posse em nome deste e no

\footnotetext{
${ }^{92}$ ANGELOTTI, Dante, op. cit., p. 97: “(...) il possesso è una res facti, uno stato di fatto e non un diritto quindi non è concepilbile una distinzione tra possesso second oil direito penale e possesso second oil diritto privato, in quanto partono due dalla identical origine: cioè dalla natura di fatto e non di diritto". ${ }^{93}$ Hungria, Nélson, Comentários ao Código Penal, vol. VII, $2^{\mathrm{a}}$ ed., Rio de Janeiro, Revista Forense, 1958. p.130.
} 
cumprimento de suas ordens ou instruções; ou o faz por mera permissão ou tolerância do proprietário. ${ }^{94}$.

De acordo ainda com Hungria, faz-se necessária esta expressa previsão da detenção, pois se o artigo 168 tratasse apenas da posse poderia haver dúvida quanto à abrangência do termo. Ou seja, para alguns o termo posse poderia compreender as situações em que há detenção, enquanto para outros não, a simples detenção estaria excluída, quer pela proibição de analogia no direito penal, quer por não estar tecnicamente abrangida no termo. ${ }^{95}$.

Desdobrando ainda a questão, para o mesmo autor, a posse direta, interessada ou não, tem por essência o exercício da posse desvigiado e incontrolada pelo dominus, sobre a coisa, ou o que ele chama de poder autônomo. Já a detenção, pode ser exercida tanto sob vigilância quanto sem, havendo apropriação indébita apenas no último caso, em que livre poder de fato sobre a coisa. Isto porque para que haja a apropriação indébita é sempre necessário que o poder de fato seja livre, sem controle e sem vigia daquele que conferiu a posse.

Também não é diferente o pensamento de Noronha, para quem, no crime de apropriação indébita, a lei primou por empregar termos rigorosamente jurídicos e de acordo com o Código Civil, pois neste delito é de excepcional importância o pressuposto de achar a coisa na posse do agente ${ }^{96}$.

Segundo Noronha, embora o direito penal, por vezes, imprima matiz próprio a conceitos do direito civil, neste delito assim não o fez. Portanto, tal como o faz o Código Civil, teria adotado a teoria de Ihering da posse, segundo a qual a posse é a relação externa entre indivíduo e a coisa: possuidor é aquele que se conduz em relação à coisa como faria o proprietário. Esclarece o autor que na doutrina de Ihering, não há diferença intrínseca entre posse e detenção, pois

\footnotetext{
${ }^{94}$ Idem. Ibidem.

${ }^{95}$ Idem. Ibidem.

${ }^{96}$ NoronhA, Edgard Magalhães, Direito Penal, vol. 2, $21^{\text {a }}$ ed., São Paulo, Saraiva, 1986. p. 330.
} 
esta possui os mesmos elementos daquela, havendo diferenciação apenas legal, isto é, existe detenção e não posse quando a lei assim o declara e vice versa.

Desta mesma forma pensa Regis Prado, para quem com o uso das expressões posse e detenção, pela lei penal, "tem-se como imprescindível a distinção feita pelo direito privado, para que se possa caracterizar a apropriação indébita, já que, se não há vigilância da coisa, o agente responde por furto, porque ausente o poder de fato pelo possuidor." ${ }^{, 97}$. Assim, para ele, a posse no crime em questão também é a posse direta, interessada ou não, ou seja, a exercida em nome de outrem, mas por conta ou em benefício próprio, de modo autônomo, isto é, sem controle pessoal do dominus. Já a detenção, segundo o autor, é exercida por mera permissão ou tolerância do proprietário, sendo um poder de fato que não signifique posse, em conformidade com os artigos 1.198 e 1208 do Código Civil.

Já Fragoso, afirma que a lei penal não usa as expressões posse e detenção com o mesmo significado que têm no Direito Civil. Para ele, a lei penal "emprega-as como sinônimas, para significar uma efetiva relação de domínio ou disposição com referência à coisa, ou como dizem Mayer-Allfed, a relação existente entre uma pessoa e uma coisa, através da qual a pessoa pode, com exclusão de qualquer outra dela dispor." 98 .

Ainda segundo este autor, a posse prevista no crime de apropriação indébita, seria a que advém do conceito de posse direta do direito civil; já o conceito de detenção envolveria uma relação de dependência entre duas pessoas, em que uma exerce a posse em nome da outra, ou por simples permissão ou por tolerância. Conclui afirmando que a detenção para configurar o delito de apropriação indébita só existe se "exercida sem vigilância ou custódia do

\footnotetext{
${ }^{97}$ Prado, Luiz Regis, Curso de Direito Penal Brasileiro - Parte Especial, vol. 2, $9^{\mathrm{a}}$ ed., São Paulo, Editora dos Tribunais, 2010. p. 422.

${ }^{98}$ Fragoso, Heleno Cláudio, Lições de Direito Penal - Parte Especial, vol. I, $8^{\mathrm{a}}$ ed., Rio de Janeiro, Forense, 1986. p. 356.
} 
proprietário, pois caso contrário, o crime seria o de furto qualificado pelo abuso de confiança"99.

Para Bitencourt para que haja posse, é necessário que o agente possa ter disponibilidade física direta ou imediata da coisa alheia subsequente à traditio voluntária, livre e consciente. Contudo, a essa disponibilidade material não deve corresponder a disponibilidade jurídica uti dominus. $\mathrm{O}$ que o agente possuía alieno domine passa a possuir causa dominii. ${ }^{100}$

De uma forma geral, diante do acima exposto, podemos concluir que a posse ou detenção da coisa pelo agente deve ser revestida dos seguintes requisitos para a caracterização do delito de apropriação indébita: tradição livre e consciente, origem legítima e disponibilidade da coisa pelo sujeito ativo. ${ }^{101} \mathrm{O}$ primeiro requisito é condição indispensável à figura de apropriação indébita, bem como o segundo, pois, se a posse ou detenção for obtida contra a vontade do dono ou possuidor, seja por violência ou fraude, existirá outro crime.

Não há divergência na doutrina quanto a necessidade da posse ou da detenção ser legitimamente exercida, justamente por ser a licitude da posse ou detenção, o fator que distingue o crime de apropriação indébita de outros crimes.

Neste ponto, é esclarecedora a lição da doutrina italiana, a qual entende a posse enquanto um autônomo poder de fato sobre a coisa (autonomo pottere di fatto sulla cosa) ${ }^{102}$. Para Angelotti, portanto, "não se requer que a legitimidade da origem da posse se estenda além da relação entre o atual possuidor e aquela imediatamente precedente, da qual a posse teve causa imediata. É necessário não esquecer que a posse é um fato e não um direito e

\footnotetext{
${ }^{99}$ Idem. Ibidem.

${ }^{100}$ Bitencourt, Cezar Roberto, Tratado de Direito Penal - Parte Especial, vol. 3, 7 a ed., São Paulo: Saraiva, 2011. p. 236

${ }^{101}$ NorOnHA, Edgard Magalhães, Direito Penal, vol. 2, $32^{\mathrm{a}}$ ed., São Paulo, Saraiva, 2001. p. 339

102 FiandacA, Giovanni, Musco, Enzo, Diritto Penale - Parte Speciale - I Delitti contro il Patrimonio, vol. II, T. 2, Bologna, Zanichelli, 2011. p. 103.
} 
como tal não é transmissível, não é suscetível de sucessão no senso jurídico moderno e bizantino. Pode-se falar somente de sucessão no tempo". ${ }^{103}$

Para o mesmo autor, "uma importante aplicação desse princípio se dá precisamente para aquelas coisas que chegaram do possuidor precedente ao atual (sujeito ativo) através de ilícito civil ou penal, de jogo ou outro ato fraudulento de antes do delito". 104

Assim, como pondera Noronha, "a legitimidade da posse ou da detenção deve ser examinada exclusivamente a respeito do sujeito do crime, ou basta ser apreciada na relação estabelecida entre o agente e a pessoa de quem houve a coisa, sem preocupações da legitimidade da posse deste.". ${ }^{105}$ Neste contexto, pode-se afirmar portanto, que é irrelevante para a configuração do delito a origem, motivo ou finalidade da posse.

De outro lado, também a cessação da legitimidade da posse ou detenção não exclui o delito de apropriação indébita. Uma vez havendo sido a posse licitamente obtida (sem clandestinidade, fraude ou violência) pelo agente, irrelevante é sua origem motivo ou finalidade. Este é o entendimento de Fragoso $^{106}$, para quem a cessação da legitimidade da posse ou detenção não exclui o crime de apropriação indébita.

Ainda, há que se asseverar que a legitimidade da posse deve ser examinada exclusivamente da perspectiva do sujeito ativo. Ainda que haja recebido coisa objeto de crime, comete apropriação indébita aquele que ignore sua origem ilícita. ${ }^{107}$

\footnotetext{
${ }^{103}$ ANGELOTTI, Dante, op. cit., p. 125: “(...) Non si richiede che la legittimità dell’origine (v. n. 91 b) del possesso si estenda oltre il rapporto tra attuale possessore e quello immediatamente precedente, da cui il possesso ha avuto causa immmediata. É necessario non dimenticare cche il possesso è um fatto enom un diritto e come tale non è trasmissibile, nè è suscettivo di successione nel senso giuridico moderno e bizantino."

${ }^{104}$ Idem. Ibidem.

${ }^{105}$ NORONHA, Edgard Magalhães, op. cit., p. 331.

${ }^{106}$ Fragoso, Heleno Claudio, op. cit., p. 45.

${ }^{107}$ NORONHA, Edgard Magalhães, op. cit., p. 339.
} 
Como já afirmado, a preexistência da posse do sujeito ativo é uma condição que constitui o pressuposto fático do delito de apropriação indébita. Nesse sentido, a lição de Bento de Faria, "a coisa deve se achar com o agente legalmente, antes da apropriação, isto é, sem subtração, fraude ou violência, pois se houvesse de recorrer a esses meios para obtê-la, ou a sua disponibilidade, praticaria delito diverso". 108

Esclarece Prado que, "a apropriação indébita, apesar de historicamente ter sido tratada como modalidade de furto e denominada pelos italianos de truffa (estelionato em português), é substancialmente distinta. $\mathrm{Na}$ apropriação, a coisa não é subtraída ou ardilosamente captada, pois já estava no legítimo e desvigiado poder de disponibilidade física do agente. No furto, no roubo e no estelionato, o poder de fato sobre a coisa é obtido com a própria ação delituosa"109.

No entanto, embora, como visto, grande parte da doutrina entenda que é indispensável que a posse seja preexistente, outra, encabeçada por Binding, admite que o dolo de apropriação possa ser contemporâneo à aquisição da posse. Entretanto, como apontado pela a doutrina italiana, se assim fosse, haveria uma interpretação contra legem, posto que na literalidade do dispositivo italiano, cuida-se de objeto "di cui abbia, a qualsiasi titolo, il possesso". ${ }^{110}$

Cumpre lembrar que, a posse do agente para caracterizar a ilicitude da conduta, não pode estar amparada por nenhum direito previsto em dispositivo da lei civil. Como exemplo podemos citar os artigos 644, 664, 681 e 708 do Código Civil, que tratam do direito de retenção, ou o artigo 368, que trata da compensação. Nesses casos, pode-se afirmar que existe o exercício regular de um direito.

\footnotetext{
${ }^{108}$ FARIA, Bento de, Código Penal Brasileiro, vol. 4, Rio de Janeiro, Livraria Jacintho Editora, 1943. p. 120.

${ }^{109}$ PrAdo, Luiz Regis, Curso de Direito Penal Brasileiro - Parte Especial, vol. 2, 9a ed., São Paulo, Editora dos Tribunais, 2010. p. 424.

${ }^{110}$ FiandaCA, Giovanni, MusCO, Enzo, op. cit., p 106.
} 
De todo o exposto, pode-se concluir que o fundamental de se notar é que a posse e a detenção para os fins de caracterização da apropriação indébita devem ser, acima de tudo, entendidas como poder de fato sobre a coisa. Essa posição, ao mesmo tempo que de nenhuma forma viola o direito civil, contempla a necessidade do direito penal de, com base no processo de distinção entre os crimes de furto e apropriação indébita, poder delimitar cada uma dessas condutas, sob a ótica da necessidade de subtração ou não do bem em questão. Havendo um poder de fato sobre a coisa, não há, por óbvio, necessidade de subtração. Não havendo tal poder e sendo necessária a subtração, está-se diante de furto. Dessa forma, pode-se até mesmo asseverar que, por vezes, a partir da própria ação praticada no caso concreto, poderá se verificar se havia posse ou não, para os fins que ora se propõe.

\subsection{O animus rem sibi habendi.}

Uma vez estabelecido o pressuposto fático do delito, consistente na posse ou detenção licita da coisa alheia móvel, há que se compreender, ainda que sucintamente, o elemento subjetivo do tipo penal de apropriação indébita, voltado à apropriação da coisa como se sua fosse, bem reveladora da natureza patrimonial (sui generis) do delito.

No dicionário, o verbo apropriar-se vem definido como: "tomar para si, tomar como propriedade; arrogar-se a posse de; apoderar(-se), assenhorear (-se)". 111

De forma abreviada podemos dizer que, no Direito Penal apropriar-se é fazer sua a coisa alheia. Em diversos tipos penais a ideia da apropriação, ainda que em sentido amplo, está presente, como no furto, no roubo e no estelionato. No entanto, em se tratando do crime apropriação indébita, a

\footnotetext{
${ }^{111}$ HouAiss, Antônio e Villar, Mauro de Salles, Dicionário Houaiss da Lingua Portuguesa, $19^{\mathrm{a}}$ ed., Rio de Janeiro, Objetiva, 2009. p. 166.
} 
apropriação da coisa deverá, como visto, obrigatoriamente, ser posterior à posse licita. Neste crime, o agente recebe a coisa de quem de direito por vontade válida e possuindo-a ou detendo-a licitamente, passa a possuí-la ut dominus, isto é, faz a coisa entrar em seu patrimônio, ou dispõe dela como se fora o dono.

Diante de tal cenário, surge a discussão quanto a existência ou não de um dolo específico para a configuração do delito. Discute-se se é suficiente para a caracterização da apropriação indébita o dolo genérico, a vontade livre e consciente de apropriação, ou se é de se exigir, também, um fim especial.

Em síntese, uma primeira corrente sustenta que é indispensável a intenção do sujeito de obter um proveito, que não precisa ser necessariamente econômico, sendo suficiente que seja injusto; para a segunda corrente é indiferente qualquer fim posterior à apropriação, sendo suficiente apenas a vontade definitiva de não restituir a coisa ou desviá-la do fim para o qual foi entregue ou o animus rem sibi habendi.

Hungria, toma clara posição ao expor que "a apropriação pressupõe, conceitualmente, a intenção definitiva de não restituir a coisa ou desviá-la do fim para que foi entregue, ou a ciência de que se torna impraticável uma coisa ou outra, é obvio que tal intenção é integrante do dolo do agente. A ausência do animus rem sibi habendi exclui, subjetivamente, a apropriação indébita. Não há que falar-se aqui de dolo específico, mas em dolo genérico"112.

No mesmo sentido, Fragoso afirma que "não se exige qualquer fim especial de agir. $O$ dolo seria o genérico, não exigindo nossa lei, como a italiana, que o agente vise proveito para si ou para outrem". ${ }^{113}$

\footnotetext{
${ }^{112}$ Hungria, Nélson, Comentários ao Código Penal, vol. VII, $2^{\mathrm{a}}$ ed., Rio de Janeiro, Revista Forense, 1958. p.138.

${ }^{113}$ Fragoso, Heleno Cláudio, Lições de Direito Penal - Parte Especial, vol. I, 8 a ed., Rio de Janeiro, Forense, 1986. p.356. No mesmo sentido se manifestam: Capez, para quem "o tipo penal não exige qualquer fim especial de agir, constituindo o dolo na vontade livre e consciente de apropriar-se da
} 
De forma diferente pensa Noronha. Para este autor, no delito de apropriação indébita, o dolo genérico consiste na vontade de inverter o titulo, pelo qual se tem a posse ou a detenção, transformando-se de possuidor alieno domine em possuidor animus domini, agindo conscientemente contra o direito, quer não restituindo a coisa, quer não lhe dando o destino determinado. Para o autor, é a partir do verbo apropriar-se, que significa tornar próprio, quer em proveito próprio ou de terceiro, que subentende-se o dolo específico do delito. Ou seja, “o dolo específico consiste em o agente praticar o fato com o fim, o escopo de lograr proveito. É o animus lucrandi, ou animus lucri facienda causa"114. Para ele, "o fim de conseguir proveito (para si ou para outrem), concretiza, pois, o dolo específico" $" 115$.

No entanto, Noronha afirma que o proveito procurado pelo agente pode não ser de ordem econômico-patrimonial. Também não é necessário que advenha lucro efetivo ao agente, ou seja, é dispensável a efetivação do proveito que este esperava, bastando que o proveito fosse injusto. Por fim completa afirmando "a existência do dolo específico, do fim de procurar proveito ilícito, é indispensável, pois sem ele a apropriação pode confundir-se com outros crime, ou mesmo não haver delito" 116 .

coisa alheia móvel sem intenção de restituí-la, ou seja, é o animus rem sibi habendi"..( CAPEZ, Fernando, Curso de Direito Penal - Parte Especial, vol. 2, São Paulo, Saraiva, 2011. p. 542); Bittencourt segundo o qual "o elemento subjetivo é o dolo, constituído pela vontade livre e consciente de apropriar-se de coisa alheia móvel de que tem a posse em nome de outrem, ou, em outros termos, a vontade definitiva de não restituir a coisa alheia ou desviá-la de sua finalidade" (BITENCOURT, Cezar Roberto, Tratado de Direito Penal - Parte Especial, vol. 3, $7^{\text {a }}$ ed., São Paulo, Saraiva, 2011. p. 238); Estefan, para quem "o elemento subjetivo específico consiste no ânimus de ter a coisa como sua, dela se apoderando definitivamente ou exaurindo a utilidade a que se destina (animus rem sibi habendi)" (Estefam, André, Direito Penal - Parte Especial, vol. 2, São Paulo, Saraiva, 2010. p. 444)" e Mirabete, para quem "o dolo no delito em questão é a vontade de apropriar-se da coisa alheia móvel, exigindo-se, como elemento subjetivo do tipo (dolo específico), a vontade de ter, como proprietário, a coisa para si ou para outrem. Assim, o dolo revela-se pela disposição do agente, que inverte o título da posse, configurando-se o crime só quando devidamente comprovada que a intenção do agente era apoderar-se da res, tornando-se seu dono". (MIRABETE, Júlio Fabbrini, Manual de Direito Penal, vol. 2, $26^{\mathrm{a}}$ ed., São Paulo, Atlas, 2009. p. 249).

${ }^{114}$ Noronha, Edgard Magalhães, Direito Penal, vol. 2, 32ª ed., São Paulo, Saraiva, 2001. p. 334.

${ }^{115}$ Nesse sentido, Nardone: "A apropriação indébita além do dolo genérico, exige um dolo específico, que se concretiza no fim de obter para si ou para outrem uma vantagem indevida". (NARDONE, Roberta, L'Infedeltà Patrimoniale degli Amministratori e l'Appropriazione Indebita, in Rivista Penale dell'Econonomia, fascículo 1, 1995. p. 89).

${ }^{116}$ NoronHA, Edgard Magalhães, Direito Penal, vol. 2, 32ª ed., São Paulo, Saraiva, 2001. p. 334. 
Prado adota posicionamento semelhante ao afirmar que é necessário, para a configuração do delito, não só o dolo, mas "o fimm especial de obter para si ou para outrem um proveito" $" 117$.

Fica claro, portanto, que o posicionamento sobre a presença de um elemento subjetivo especial no tipo penal de apropriação indébita, depende, em tudo, da concepção que se tenha da natureza jurídica do delito e do âmbito de proteção da norma.

A afirmação da necessidade da busca de um proveito para a configuração do delito, nesse sentido, guardaria correspondência com uma concepção de um tipo penal mais voltado à defesa do patrimônio, o que se afasta, mais adiante, no presente trabalho.

De outro lado a necessidade, suficiente, da presença de um elemento subjetivo geral, consistente na vontade definitiva de não restituir a coisa ou desviá-la do fim para o qual foi entregue (animus rem sibi habendi), parece ligada à concepção de que o bem jurídico protegido pelo tipo penal em questão é propriedade (ou mesmo a liberdade de disposição do proprietário sobre a coisa, como se sustentará mais adiante) e se mostra mais consentânea, como se pretende demonstrar mais adiante, com a estrutura material do delito e com a natureza de um crime patrimonial (sui generis).

\subsection{Conduta típica de apropriação indébita e suas modalidades.}

Pode-se assim afirmar-se que, "na apropriação há uma conjunção de um estado de ânimo, a intenção de fazer própria a coisa que é de

\footnotetext{
${ }^{117}$ Prado, Luiz Regis, Curso de Direito Penal Brasileiro - Parte Especial, vol. 2, 9a ed., São Paulo, Editora dos Tribunais, 2010. p. 423. Afirma o autor, na nota 27, que acolhem este mesmo posicionamento González Rus, para quem o subjetivo do injusto "servirá para excluir do âmbito do tipo os atos dispositivos realizados com o simples propósito de utilização, que ficam relegados com o âmbito civil. Também entendendo ser preciso o elemento subjetivo do injusto (ânimo de lucro), Serrano Gomez".
} 
outrem, com um comportamento material que exteriorize tal intenção, comportamento este exigível para que exista a execução do delito" ${ }^{118}$.

Para Antolisei, "na apropriação a questão está centrada na conduta do agente, que se comporta perante a coisa como se esta lhe pertencesse, como se lhe fora própria, isto é assume arbitrariamente faculdades de proprietário, exercendo sobre ela atos de uso e disposição que não estavam autorizados pelo título em virtude do qual recebeu a coisa e a possui ${ }^{119}$.

No entanto, conforme Conde-Pumpido, "convém assinalar que embora hajam faculdades próprias do domínio cujo exercício revelam inequivocamente que se pretende ter a coisa como própria, como o aliená-la, transformá-la, consumí-la ou destruí-la, existem outras como o direito de usá-la ou de possuí-la, excluindo terceiros dessa posse, podem gerar dúvidas quanto a serem ou mero exercício dessas faculdades, já que podem submeter-se a outros títulos ou intenções distintas da de fazer própria a coisa. O que conduz a duas das questões que são polêmicas nesta matéria: as apropriações omissivas e a chamada apropriação de uso." ${ }^{120}$.

De fato, diversas são as modalidades pela quais se pode dar a apropriação da coisa pelo agente.

\footnotetext{
${ }^{118}$ CONDE-PumPIDO, Cándido Ferreiro, Apropriaciones Indebidas, Valencia, Tirant lo Blanch, 1997. p.104: "Ha de darse para estimar que existe apropiación la conjunción de un estado de ánimo intención de hacer propia la cosa que es de otro- con un comportamiento material que exterio- rice tal intención, condición de exteriorización de la intención que es exigible para entender existe la ejecución de cualquier delito" (tradução nossa).

${ }^{119}$ Idem. p. 105: "Por ello (Antolisei) hay que insistir que la apropiación radica no en la creación de una situación de Derecho sino en la conducta del agente que se comporta de hecho frente a la cosa como si le perteneciere, como si fuere propia, esto es, asume arbitrariamente facultades del propietario, ejerciendo sobre ella actos de disfrute o disposición que no están autorizados por el título en virtud del que la recibió y la está poseyendo" (tradução nossa).

${ }^{120}$ Idem. Ibidem. "Conviene también señalar que si bien hay facultades propias del dominio cuyo ejercicio revelan inequívocamente que se pretende tener la cosa como propia, como el enajenarla, transformarla, consumirla o destruirla, existen otras, como el dere- cho de usarla o de poseerla excluyendo a terceros de esa posesión, que pueden plantear dudas en cuanto el mero ejercicio de esas facultades puede obedecer a otros títulos o intenciones distintos a la de hacer propia de cosa. Lo que conduce a dos de las cuestiones que son polémicas en esta materia: las apropiaciones omisivas y la llamada apropiación indebida de uso."
} 
Noronha expõe as formas de apropriação, classificando-as em consumo (que poderá consistir na alteração ou transformação da coisa também, como exemplificado pelo autor no caso do ourives a quem é entregue um anel que vem a fundido para dar forma a outro) ${ }^{121}$, alheação (na forma de venda, doação, cessão, penhor, ocultação, caução, etc), retenção (que poderá levar à tipicidade quando o agente não quer devolver o objeto ou dar-lhe o destino conveniente, consoante o titulo que recebeu) e o desvio.

Quanto à não restituição e a recusa em devolver, afirma Noronha que nestas condutas o dolo do agente em apropriar-se da coisa alheia móvel deverá estar presente para levar à tipificação do delito em questão. No entanto, afirma o autor que a não restituição no seu devido tempo, pode ser prova do crime, quando junto com os outros elementos do delito.

Diante do que, afirma Hungria que o reconhecimento da apropriação é uma quaestio facti a ser resolvida, caso a caso, pelo juiz, mas que por vezes denuncia-se ela ipso júris (ex. A venda de coisa infungível recebida em depósito ou locação); e outras vezes faz-se necessária uma detida apreciação das comprovadas circunstâncias ${ }^{122}$.

Hungria dá como exemplo da não configuração do crime de apropriação indébita, a conduta de não restituição, o caso de credor pignoratício que necessitando de dinheiro, realiza um ilegal sub penhor de coisa recebida por ele em garantia, com a intenção efetiva de resgatar e restituir a coisa oportunamente, desde que o credor pignoratício tenha capacidade financeira. Também para o autor, em caso de coisa fungível (ausente cláusula permissiva de substituição pelo tantumdem) somente a própria alienação ou consumo não constitui apropriação indébita, sendo necessário verificar se o agente, embora infringindo um contrato, estava com o propósito de restituir a coisa no tempo oportuno. Para ele inclusive, “ o fato não excederá o âmbito civil, ainda quando,

\footnotetext{
${ }^{121}$ NORONHA, Edgard Magalhães, op. cit., p. 332.

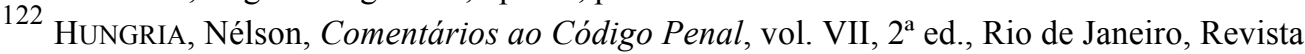
Forense, 1958. p. 136.
} 
por causas imprevistas, o agente venha cair em insolvência" ${ }^{\text {2123 }}$, pois a capacidade financeira do agente deve ser aferida ao tempo do ato de disposição.

Com relação à não restituição, em resumo, pode-se afirmar com Hungria que, estando a coisa com o agente, a simples negativa de restituição ou omissão de emprego ao fim a que foi determinado não significa, que há apropriação indébita, pois é necessário que "a negativa ou omissão seja precedida ou acompanhada de circunstâncias que inequivocamente revelem o arbitrário animus rem sibi habendi, ou que não haja qualquer fundamento legal ou motivo razoável para a recusa ou omissão“124. Assim, a simples mora em restituir, ou a simples desídia no omitir, não é apropriação.

Ainda de acordo com Hungria, "não há apropriação indébita de uso (posto, como é óbvio, que o uso não seja incompatível com a possibilidade de ulterior restituição da coisa ou seu emprego ao fim determinado). Se, por exemplo, o depositário de um cavalo ou de um automóvel se serve dele para um simples passeio, haverá abuso de posse, mas não apropriação indébita". ${ }^{25}$

Nesse sentido, para o autor, é necessário que "fique averiguado, de modo convincente, o propósito de não restituir ou a consciência de não mais poder restituir." "126 Isto porque, na figura da apropriação indébita, somente a própria alienação ou consumo não levará à consumação do crime, sendo necessário também, verificar se o agente, embora infringindo o contrato por pressão de circunstâncias, estava no propósito de oportuno tempore, restituir o tantumdem.

No direito espanhol, como bem aponta Conde-Pumpido 127 "o uso indevido ou não autorizado da coisa sem animus rei sibi habendi, é uma

\footnotetext{
${ }^{123}$ Idem. Ibidem.

${ }^{124}$ Idem, p. 135.

125 Idem, p. 137.

${ }^{126}$ Idem, p. 135.

${ }^{127}$ CONDE-PuMPIDO, Cándido Ferreiro, p. 104: "El uso indebido o no autorizado de la cosa sin animus rei sibi habendi, es causa de polémica. CARRARA era partidário de estimar el delito de apropiación indebida cuando se producían usos de la cosa que el título en virtud de que se poseía no autorizaban,
} 
causa de polêmica. Segundo este autor, Carrara julgava não haver o delito de apropriação indébita quando havia o uso da coisa de forma diversa da autorizada pelo título que transferira a posse, sendo este uso excessivo configuração de um ilícito civil. De forma diversa, expõe o autor, Manzini distingue entra a mera apropriação de uso, que seria um simples abuso de posse, do uso revelador de uma apropriação total da coisa em que haveria o delito. Daí, como adverte Conde-Pumpido, não seria mais um mero uso mais uma apropriação. Na doutrina espanhola, Ferrer Sama não reconhece a apropriação indébita de uso, conforme uma corrente doutrinária não de todo pacífica, nem majoritária.

No entanto, foi Zugaldia Espinar ${ }^{128}$ quem discorreu sobre a matéria recentemente e de modo mais técnico e profundo quanto à sua natureza. Para solucionar o problema, entende ser fundamental distinguir-se as classes de usos que podem supor a apropriação da coisa e as classes de usos que não supõem. Assim, enquanto o uso da coisa suponha sua efetiva apropriação ou seja uma conseqüência dela, nos encontraremos diante de um ato típico. E quando o uso da coisa não integre a sua apropriação, o ato será impune pois atípico.

\section{Conde-Pumpido resume a questão aduzindo ${ }^{129}$ : a) se o uso da} coisa não está incluído no título pelo qual recebeu a coisa, é transitório e não afeta

mientras que si el uso era una de las facultades concedidas por el título posesorio (así, comodato, arrendamiento, etc.) el uso excesivo de la cosa constituía solo un ilícito civil. Otros como MANZINI distinguen entre «la mera apropiación de uso», esto es, el simple abuso de la posesión, que estima impune, y el uso revelador de una apropiación total de la cosa, en que existiría el delito. Pero entonces, obviamente, ya no sería un mero uso, sino una apropiación o intención de hacer propia la cosa, revelada a través del ejercicio de una facultad de la propiedad ilícitamente arrogada: el uso. En la doctrina patria FERRER SAMA rechaza la tipicidad de la apropiación indebida de uso, en paralelismo con el hurto de uso que también estima atípico, conforme a una corriente doctrinal no del todo pacífica aunque mayoritaria" (tradução nossa).

${ }^{128}$ Idem, p. 106: "Pero para establecer tal distinción es fundamental determinar qué clase de usos pueden suponer la apropiación de la cosa y qué clase de usos no la suponen. Para ello una de las primeras ideas cuya errónea formulación hay que poner de relieve es la de que el propósito de restituir excluye el ánimo de apropiación, en cuanto el propósito de apropiarse lo ajeno lleva consigo el hacerlo de modo definitivo, esto es, expropiar de la cosa a su legítimo titular. Eso no es siempre cierto, pues puede existir una ánimo apropiatorio temporal pero que represente expropiar de la cosa a un titular, satisfaciendo así el núcleo de la conducta típica."(tradução nossa).

${ }^{129}$ Idem, p. 107: "En consecuencia estimamos que: a) si el uso de la cosa no incluido en el título por el que se recibió aquella, es transitorio y no afecta sustancialmente al valor de la cosa ni al ejercicio del derecho de propiedad por su titular legítimo, habrá apropiación indebida de uso, en principio atípica; y b) si el uso conlleva, bien la expropiación de parte del valor de la cosa, bien una privación significativa por su duración o trascendencia (necesidad del propietario de recuperar y usar a su vez la cosa) de las 
substancialmente o valor da coisa nem o exercício do direito de propriedade por seu proprietário legítimo, haverá apropriação indébita de uso, em princípio atípica; e b) se o uso suporta, a apropriação de parte do valor da coisa, ou uma privação significativa devido 'a duração ou transcendência (necessidade do proprietário de recuperar e usar por sua vez a coisa) das faculdades dominiais do proprietário, haverá apropriação da coisa e consequentemente, o ato será típico. Em outras palavras, o uso da coisa fora dos limites autorizados, ou prolongando essa utilização, ou além do prazo pactuado, ou depois de receber um requerimento de devolução, ainda que terminando por restituir voluntariamente a coisa a seu titular, é apropriação indébita de uso. Nestes casos, a apropriação da coisa pode se dar, ainda que de forma parcial sempre que, por exemplo, o uso do objeto resulte na diminuição do seu valor, acarretando uma perda para o seu proprietário $^{130}$.

Quanto à apropriação por retenção, quando a coisa continua em poder do agente, ou não tenha sido por ele alienada ou consumida, a simples negativa de restituição ou a omissão de emprego ao fim a que era destinava não significa que, embora contra a lei, esteja-se diante de uma apropriação indébita. Isto porque, "para que haja a apropriação indébita é indispensável que a negativa ou omissão seja precedida ou acompanhada de circunstâncias que inequivocamente revelem o arbitrário animus rem sibi habendi, ou que não haja, qualquer fundamento legal ou motivo razoável para a recusa ou omissão". ${ }^{131}$

$\mathrm{Na}$ doutrina italiana, sobre a apropriação por retenção, diz Ferrari com razão que "não parece que o puro e simples comportamento omissivo (o não restituir a coisa) possa, sozinho constituir uma apropriação. Mais

\footnotetext{
facultades dominicales del propietario, habrá apropiación de la cosa y, en consecuencia, el hecho será típico" En otras palabras, hasta donde el uso de la cosa suponga su efectiva apropiación o sea una consecuencia de ella nos encontraremos ante un acto típico. Allí donde el uso de la cosa no integre su apropiación el acto será impune, por atípico". (tradução nossa).

${ }^{130}$ Idem, p. 108: "En lo que hace al uso de la cosa más allá de lo que el título y el plazo de la relación jurídica en virtud de la que se recibió, se estima que aunque exista devolución de la cosa puede darse una apropiación de la misma, al menos en forma parcial siempre que: 1) El uso del objeto disminuya su valor, de forma que aquel es devuelto con su valor mermado, perjudicándose así en una cierta parte del valor de la cosa al propietario".

${ }^{131}$ HUNGRIA, Nélson, op. cit., p.135.
} 
precisamente, admitir uma apropriação omissiva, de fora do âmbito de aplicação do art. 40, comma, c.p., conduz a uma violação do princípio da tipicidade; além do mais, o fato de não restituir a coisa não é suficientemente inequívoco como expressão de realização de uma vontade de apropriar-se da coisa: afirmar o contrário, conduz à violação do princípio da materialidade. Portanto, na apropriação é essencial uma conduta positiva, que é a recusa explícita de restituir, o procrastinar a restituição, alegando pretexto, o esconder o objeto, o negar de havê-lo recebido, etc ${ }^{132 \% " . ~ E ~ c o n t i n u a, ~ " n e s t e ~ c o n t e x t o, ~ n a ̃ o ~ h a ́ ~ d u ́ v i d a ~ q u e ~ a ~}$ conduta de reter pode assumir a forma positiva de uma verdadeira apropriação da coisa, mas pode consistir também na pura e simples omissão de restituição ou na omissão de transferência". A inobservância da obrigação civil, por si, não é fonte de responsabilidade penal. $" 133$.

Também para Fragoso, "no que concerne à retenção, não é indispensável que seja o agente constituído em mora, mas o simples inadimplemento contratual não deve ser confundido com a apropriação."134

Por essa razão destaca Antolisei, como já visto, que pode surgir incerteza quanto aquela forma de apropriação consistente na retenção da coisa, de caráter omissivo, mas também neste caso, segundo o autor, "um comportamento

\footnotetext{
132 "Nom sembra que il puro e simplece comportamento omissivo (il nom restituire la cosa) possa, da solo, costituire un'appropriazione omissiva, al fuori dell'ambito di applicabilità dell'art.40, $2^{\mathrm{a}}$ comma, c.p., conduce a una violazione del principio di tipicità; inoltre, il fatto di non restituire la cosa non è abbastanza, univoco nell'esprimere la realizzazione di una volontà di appropriarsi della cosa: affermare il contrario conduce altresì a violare il principiuo di materialità. Pertanto, all'aappropriazione è essenziale una condottta positiva, quale il rifiuto esplicito di restituire, il procrastinare la restituzione adducendo motivi pretestuosi, il nascondere l'oggetto, il negare di averlo mai ricevuto, ecc.... In questo contesto non v'è dubbio che la condotta del "ritenere" può assumere la forma positiva di una vera apprpriazione della cosa, ma può consistere anche nella pura e semplice omessa restituzione o nell'omesso trasferimento" (tradução nossa). FERRARI, Simone, Diritto Penale Appropriazione Mediante Ritenzione, in Giurisprudenza Italiana, Torino, UTET, Aprile 2008. p. 967. ${ }^{133}$ Idem, p. 968.

${ }^{134}$ Fragoso, Heleno Cláudio, Lições de Direito Penal - Parte Especial, vol. I, $8^{\mathrm{a}}$ ed., Rio de Janeiro, Forense, 1986. p. 358.
} 
externo, a comprovar a vontade de não restituir, deve considerar-se indispensável". 135

${ }^{135}$ Antolisei, Francesco, Manuale di Diritto Penale, vol. 1, Milano, Giuffrè, 1994. p. 355: “(...) un comportamento esterno comprovante la volontà di non restituire la cosa deve considerarsi indispensabile" (tradução nossa). 


\section{ESTRUTURA TÍPICA E ECONOMIA DO DELITO: CONSUMAÇÃO E TENTATIVA DE APROPRIAÇÃO INDÉBITA NO DIREITO PENAL BRASILEIRO}

SUMÁRIO: 3.1 Recolocação do problema: as experiências brasileira e italiana. 3.2 A relação entre tipo subjetivo e tipo objetivo no delito de apropriação indébita: a apropriação como pensamento e ação. 3.3 Tutela penal da propriedade e legitimidade do Direito Penal: a questão do bem jurídico protegido pelo tipo penal de apropriação indébita. 3.4 Estrutura típica e economia do delito: a apropriação como ação e como resultado. 3.5 Consumação e tentativa de apropriação indébita no Direito Penal brasileiro.

\subsection{Recolocação do problema: as experiências brasileira e italiana.}

Uma vez compreendidos os elementos constitutivos essenciais do tipo penal de apropriação indébita — ou, em outras palavras, suas invariáveis elementares — , é preciso perquirir de que forma tais elementos se relacionam, 
com o que, ao compreender a economia do delito, desvela-se também sua estrutura e, portanto, a natureza e o sentido do crime de apropriação indébita no Direito Penal brasileiro.

É preciso, de outra sorte, recolocar o problema central do presente trabalho, relacionado à compreensão da estrutura típica e economia do delito de apropriação indébita, e, portanto, da consumação e tentativa desse delito, iniciando a sua resolução através do interessante cotejo entre as experiências brasileira e italiana.

Nesse ponto, deve-se relembrar que a doutrina brasileira parece não perceber as contradições que se impôs no tema da consumação e tentativa do delito de apropriação indébita, o que acaba por gerar insegurança jurídica e, indo além, injustiça.

Com efeito, como já destacado, ao enxergar o ato de apropriação essencialmente como mera revelação do animus rem sibi abendi, suficiente à fixação do momento consumativo do crime, acaba-se por atribuir, inconscientemente, natureza formal ao delito de apropriação indébita, em que pese a afirmação, unânime na doutrina brasileira, de se tratar de crime material.

Tal situação, na qual se denomina crime material aquilo que se trata por crime formal (como já demonstrado), não pode deixar de conduzir às contradições doutrinárias mais relevantes e, por derradeiro, à própria incompreensão da estrutura típica real da apropriação indébita. Ao admitir-se, na letra do texto, a tentativa (por se tratar de crime material), para depois restringi-la às hipóteses de conduta plurissubsistente (o que é próprio dos crimes formais), aprofunda-se a confusão.

Assim, repita-se, como visto no primeiro capítulo, a incompatibilidade entre os conceitos de crime formal e crime material acaba obrigando vários autores a se contradizerem e, por amor à justiça, para admitir a 
tentativa, denominarem de crime material o que antes descreveram e trataram, em realidade, como crime formal. Enquanto isso, outros autores, por amor à técnica, acabam aceitando a situação que se mostra de todo injusta de imposição de pena por crime consumado a condutas que não geram qualquer lesão ao bem jurídico protegido pelo tipo penal, para sustentarem sua ideia, ainda que implícita, de que se trata de crime formal.

Consequência desse impasse teórico, a verdade é que doutrina e jurisprudência brasileiras não enfrentaram ainda a contradição entre o caráter formal de fato atribuído ao tipo penal de apropriação indébita e o discurso jurídico dominante, que o trata como crime material. Prevalece entre nós uma interpretação essencialmente casuística e positivista, insuficiente para resolver a questão posta, mas que aparentemente satisfaz a grande maioria dos autores.

Resta evidente, portanto e desde o início, a necessidade de se buscar no Direito estrangeiro, especialmente no que este tem de mais tradicional, alguns indicativos de quais seriam os problemas de fundo a serem solucionados e onde estariam as particularidades da doutrina brasileira para, enfim, poder propor caminhos para a solução dos problemas.

Primeiro, é preciso dizer que os brasileiros não estão sozinhos: a mais tradicional doutrina italiana também apresenta, em parte, um razoável grau de indefinição e contradição.

Há, porém, ainda em termos peninsulares, uma sustentação mais clara da natureza formal do delito de apropriação indébita, razão pela qual a maior parte dos autores italianos inadmite a tentativa. Ao compreender seus argumentos, é possível verificar, como se verá, que, de fato, nossa doutrina se contradiz. Com isso, estabelece-se o diálogo inicial sem o qual não seria possível a recolocação do problema em seus devidos termos e tampouco sua solução. Daí 
porque se faz necessária a presente incursão, um pouco mais extensa que de costume, no Direito Penal italiano. ${ }^{136}$

Lembrado por todos, Vincenzo Manzini assevera que a apropriação indébita é delito de dano ${ }^{137}$, limitando-se a afirmar, inicial e singelamente, que tal crime se consumaria no momento e no local nos quais se verificaria a apropriação. ${ }^{138}$

Ao tratar da ação da conduta de apropriação, no entanto, o ilustre professor completa seu pensamento, afirmando que a apropriação consiste no "fato de dispor, como proprietário, da coisa alheia móvel, da qual se tem somente a posse, de modo a privar da coisa em si, quem de direito". ${ }^{39}$

Tal assertiva poderia conduzir à conclusão de que não há crime consumado sem a violação concreta do direito de propriedade, na medida em que se refere à privação da coisa como critério de consumação do delito de apropriação indébita, o que, aliás, seria coerente com a afirmação de se tratar de crime material ou de dano.

${ }^{136}$ O tipo penal de "appropriazione indebita" constante do Código Penal italiano não difere do brasileiro no essencial. Estabelece o art. 646 do CPIt que: "Chiunque, per procurare a sé o ad altri un ingiusto profitto, si appropria il denaro o la cosa mobili altrui di cui abbia, a qualsiasi titolo, il possesso, è punito, a querela della persona offesa, con la reclusione fino a tre anni e con la multa fino a euro 1.032. Se il fatto è commesso su cose possedute a titolo di deposito necessario, la pena è aumentata. Si procede d'ufficio, se ricorre la circostanza indicata nel capoverso precedente o taluna delle circostanze indicate nel numero 11 dell'articolo 61" ["Quem, com o intuito de obter para si ou para outrem vantagem indevida, se apropria de dinheiro ou de coisa alheia móvel da qual tinha, a qualquer título, a posse, é punido, mediante representação da pessoa ofendida, com reclusão de até três anos e com multa de até 1.032 euros. Se o fato é cometido sobre coisa possuída a título de depósito necessário, a pena é aumentada. Se procede de ofício, se ocorre a circunstância indicada no parágrafo anterior ou alguma das circunstâncias indicadas no ítem 11 do artigo 61"] (Tradução nossa). Para que fique completa a citação, vale destacar a redação do artigo 61 do CPIt, mencionado no corpo do texto legal: "Art. 61 - Circostanze aggravanti comuni - Aggravano il reato, quando non ne sono elementi costitutivi o circostanze aggravanti speciale, le circostanze seguenti: 11) l'avere commesso il fato con abuso di autorità o di relazioni domestiche, ovvero con abuso di relazioni di ufficio, di prestazione d'opera, di coabitazione, o di ospitalità." [Art. 61 - Circunstâncias agravantes comuns Agravam o crime, quando não são elementos constitutivos ou circunstâncias agravantes especiais, as circunstâncias seguintes: 11) haver cometido o fato com abuso de autoridade ou de relações domésticas ou, ainda, com abuso das relações de trabalho, de prestação de serviços, de coabitação ou de hospitalidade] (tradução nossa).

${ }^{137}$ ManzInI, Vincenzo, Trattato di Diritto Penale Italiano, vol. 9, Torino, Ariel, 1952, p. 823.

${ }^{138}$ Idem, p. 824.

${ }^{139}$ Idem, p. 814. “(...) fatto di disporre come proprietário della cosa mobile altrui, della quale si ha il solo possesso, in modo da privare della cosa stessa l'avente dirittto" (tradução nossa). 
Ocorre que, por outro lado, Manzini incorpora às suas ideias o relatório do presidente da comissão ministerial para o projeto de Código Penal, Rocco, segundo o qual "o conteúdo do delito é a lesão ao direito de propriedade por parte do possuidor, o qual se substitui ao proprietário, fazendo sua a coisa. Apropriar uma coisa significa, portanto, fazê-la entrar no próprio domínio, o que, no delito em exame se verifica através da inversão da posse". ${ }^{140}$

Destaca ainda o autor italiano que "o momento consumativo do delito não coincide necessariamente com aquele da conversão da coisa em proveito próprio ou alheio, mas verifica-se assim que o agente haja se apropriado da coisa, de qualquer modo"141, o que parece próprio, aliás, da atribuição, ainda que implícita e contraditória, de caráter formal ao delito de apropriação indébita.

No mesmo sentido, logo após apontar que "para a consumação do delito a lei não requer expressamente a verificação de um dano" ${ }^{142}$, defende Manzini que "o delito em exame é de fato um crime de dano, e não de mero perigo, mas para constituí-lo é suficiente que necessariamente, e sempre, seja inerente ao fato da apropriação"143, concluindo, por fim, que "não se deve confundir este dano, necessário e suficiente, com aquele maior prejuízo que pode derivar da perda definitiva da coisa por parte do proprietário ou de outra causa similar". 144

De outro lado, no tratamento da tentativa, Manzini limita-se a afirmar que "raramente pode apresentar-se a figura da tentativa. Dado que a coisa

\footnotetext{
${ }^{140}$ MANZINI, Vincenzo, op. cit., p. 814 “(...) il contenuto del delitto è la lesione del diritto di proprietà da parte del possessore, il quale si sostituisce al proprietario, facendo sua la cosa. Appropriarsi una cosa significa appunto farla entrare nel proprio domínio, il che, nel delito in esame, si verifica mercê l'inversione del possesso" (tradução nossa).

${ }^{141}$ Idem, p. 824. “(...) il momento consumativo del delitto con coincide necessariamente con quello della conversione della cosa in profitto próprio o d'altri, ma si verifica appena l'agente si sia appropriato la cosa in un modo qualsiasi" (tradução nossa).

${ }^{142}$ Idem, p. 825. "(...) per la consumazione del delitto la legge non richiede espressamente la verificazione di un danno". (tradução nossa)

${ }^{143}$ Idem. Ibidem. "(...) il delito in esame è bensì reato di danno, e no di mero pericolo, ma per costituirlo è sufficiente quel danno Che necessariamente e sempre inerisce al fatto dell'appropiazione" (tradução nossa).

${ }^{144}$ Idem. Ibidem. “(...) non si deve confondere questo danno necessario e sufficiente, con quel maggior pregiudizio che può derivare dalla perdita definitiva della cosa da parte del proprietário, o da altre simili cause" (tradução nossa).
} 
deve já estar na posse do agente e que a apropriação consiste essencialmente em uma atuação imediata de vontade, é difícil que o fato concreto se preste a uma transição executiva da intenção ao ato consumativo", ${ }^{145}$ asseverando que só não se pode inadmitir de forma absoluta a tentativa em razão de o código italiano punir como tentativa também os atos preparatórios, idôneos à produção do resultado e dirigidos de modo inequívoco a cometer um crime, o que equivaleria a dizer, no sistema brasileiro, que não se admite a tentativa ${ }^{146}$, já que, por aqui, não se empresta tal significado aos atos preparatórios.

Com isso, fica clara no pensamento de Manzini a mesma espécie de contradição que permeia a doutrina brasileira. Ao admitir a tentativa de apropriação indébita somente em razão da possibilidade de punição dos atos preparatórios própria do Direito italiano, e apenas nesse caso, Manzini, embora atribua ao crime natureza material, acaba por tratá-lo como crime formal, sob o argumento de tratar-se de crime em que basta uma atuação imediata da vontade, em que a consumação seria inerente à conduta.

Sua contradição, no entanto, parece ser mais terminológica do que estrutural. Ao contrário de Hungria, que, após atribuir natureza formal ao delito acaba por reconhecer a possibilidade de tentativa, para depois novamente limitá-la aos casos de conduta plurissubsistente (o que, como já visto, retorce a estrutura do delito), Manzini segue a lógica do crime formal até as últimas consequências, inadmitindo sua tentativa.

É interessante notar, então, que no mesmo momento histórico, de grande destaque para o Direito Penal italiano, Biagio Petrocelli, em importante monografia sobre o tema, acaba por delinear de forma mais clara essa mesma visão da estrutura do delito, ausentes as contradições terminológicas, para

\footnotetext{
${ }^{145}$ MANZINI, Vincenzo, op. cit., p. 825 “(...) Puó raramente presentarsi la figura del tentativo. Dato Che la cosa deve giá trovarsi nel possesso dell'agente, e che l'appropriazione consiste essenzialmente in una immediata attuazione di volontà, è difficilè che il fatto concreto si presti ad una transizione esecutiva dalla intenzione all'atto consumativo" (tradução nossa).

${ }^{146}$ Idem. Ibidem.
} 
afirmar, sem margem à dúvida, a concepção do crime de apropriação indébita como crime formal, que, portanto, não admite a tentativa.

Para Petrocelli, "na apropriação mediante retenção, crime omissivo em sentido verdadeiro e próprio, o resultado, bem entendido, falta de todo e não há mais que um permanecer inalterado do estado de coisas preexistente""147, enquanto "nas outras formas de apropriação (consumo, alienação, distração) o resultado não é daqueles que se possa claramente destacar da ação"148, o que bem demonstraria, segundo o autor, que "a apropriação indébita vem a ser, do mesmo modo do furto, um crime formal". ${ }^{149}$

Quanto à consumação do delito, atribui o autor a dificuldade para o estabelecimento de um critério seguro a duas ordens de fatores: "a variedade das manifestações do delito, não submetidas ao exame de uma precisa classificação, e o fato de algumas formas de apropriação serem tais que, embora havendo a vontade atuado plenamente numa conduta em si suficiente para realizar a objetividade do delito, esta nem sempre consegue ser exteriormente patente, donde [decorre] a distração da atenção para atos que constituem a prova da apropriação ocorrida, e não propriamente a sua consumação". ${ }^{150}$

Tal observação, aliás, é bom que já se diga, parece em tudo explicar as dificuldades enfrentadas pela doutrina brasileira, que, frequentemente, trata como momento consumativo o que, na verdade, parece acreditar ser o momento de prova do delito.

\footnotetext{
147 Petrocelli, Biagio, L'Appropriazione Indebita, Napoli, Alberto Morano, 1933, p. 408. "Nell'appropriazione mediante ritenzione, reato omissivo in senso vero e próprio, l'evento, così inteso, manca del tutto, e non v'ha che un permanere imutato dello stato di fatto preesistente" (tradução nossa).

${ }^{148}$ Idem. Ibidem. "Nelle altre forme dell'appropriazione (consumazione, alienazione, distrazione) l'evento non è di quelli che possano nettamente distacarsi dall'azione” (tradução nossa).

${ }^{149}$ Idem, p. 409. "L'appropriazione indébita pertanto viene ad essere ,alla stessa guisa del furto, un reato formale" (tradução nossa). Pode-se questionar, é claro, a natureza formal atribuída pelo autor ao crime de furto, que, na ampla maioria das vezes, é descrito, com razão, como crime material a atingir a propriedade.

${ }^{150}$ Idem, p. 410. “(...) la varietà delle manifestazioni del delitto, non sottoposte al vaglio di una precisa classificazione, e l'essere alcune forme di appropriazione tali che, pur essendosi la volontá pienamente attuata in una condotta sufficiente in sè à realizzare l'obbiettività del delito, questa non sempre riesce ad essere esteriormente palese, onde il divergere dell'attenzione verso atti che costituiscono la prova dell'appropriazione avvenuta, e non propriamente la sua consumazione" (tradução nossa).
} 
Em razão de tais dificuldades, Petrocelli propõe a fixação dos critérios de consumação do delito, de forma casuística e de acordo com as modalidades de apropriação indébita, da seguinte maneira:

a) em caso de consumo, a consumação se daria "no momento no qual é realizado qualquer ato de utilização direta da coisa, que a consuma, ainda que somente em parte"; 151

b) em caso de alienação, a consumação ocorreria "no momento no qual se opera a transferência da coisa a outrem, seja a que consista na passagem direta e material da coisa do réu ao adquirente, donatário, credor, seja a que consiste na simples colocação à disposição da coisa (por exemplo, entrega das chaves do local onde se encontra custodiada a coisa)". ${ }^{152}$

c) em caso de retenção, a consumação se daria "no momento no qual, tendo-se aperfeiçoado a obrigação de restituir a coisa ou de fazer o uso devido, o agente, com a vontade de apropriar-se da coisa, deixa de adimplir com tal obrigação, mantendo imutável o estado de fato preexistente". ${ }^{153}$

Com tais considerações, um pouco inseguras e contraditórias quanto à espécie, de Manzini, e mais assertivas, de Petrocelli, é possível asseverar que no nascedouro do século XX a doutrina italiana se encaminhava com vigor para a inadmissão da tentativa de apropriação indébita por considerá-la, explícita ou implicitamente, um crime formal.

Logo adiante, no pós-guerra, Cesare Pedrazzi reafirma a tradicional doutrina italiana quanto ao caráter formal do delito e dá grande relevo

\footnotetext{
${ }^{151}$ Petrocelli, Biagio, op. cit., p. 414. “(...) nel momento in cui si compie qualunque atto di diretta utilizzazione della cosa, che la consumi, anche solo in parte” (tradução nossa).

${ }^{152}$ Idem, p. 415. “(...) nel momento in cui si opera il trasferimento della cosa in altri, sia che consista nel materiale e diretto passagio della cosa dal reo all'acquirente, donatário, crediotre, sia que consista nella semplice messa a disposizione della cosa (es. consegna dellc chiavi del locale ove la cosa é custodita" (tradução nossa).

${ }^{153}$ Idem. Ibidem. “(...) nel momento in cui, maturatosi l'obbligo di restituire la cosa o di farne l'uso dovuto, l'agente, con la volontà di appropriarsi la cosa, ometta di adempiere a quest'obbligo, lasciando immutato lo stato di fatto preesistente" (tradução nossa).
} 
ao elemento subjetivo do tipo para afirmar que "a apropriação indébita é crime instantâneo, que se consuma com o manifestar-se da vontade de senhoria absoluta sobre a coisa". ${ }^{154}$ Tal supervalorização do elemento subjetivo acaba por tornar mais fundas as raízes da doutrina subjetivista, que considera formal o delito de apropriação indébita e resta por demonstrar a estreita proximidade da doutrina brasileira com a concepção desse importante autor peninsular.

Pedrazzi considera ainda que a consumação do delito realiza-se no caso da alienação ou consumo da coisa alheia "com a conclusão dos ditos atos, ainda que o termo fixado para a restituição não tenha sido ainda esgotado", 155 enquanto, na conduta omissiva, "a consumação coincide com o término do período no qual o ato devido deveria realizar-se", ${ }^{156}$ o que, como visto, nada mais é que a linha básica de atuação dos nossos tribunais, quando não contradizem seus próprios postulados.

No que diz respeito à tentativa, para Pedrazzi, “dada a peculiar estrutura deste tipo penal, afigura-se muito difícil, para não dizer impossível, configurar-se uma hipótese de tentativa", pois a conduta exterior, de fato, teria "unicamente a função de manifestar a mudança de atitude do sujeito em relação à coisa, a superveniente vontade de domínio", ${ }^{157}$ razão pela qual para o autor considera, por exemplo, que "o simples fato de oferecer à venda uma coisa basta para dar vida a uma apropriação consumada, ainda que o réu não encontre adquirente". ${ }^{158}$

\footnotetext{
${ }^{154}$ PeDRAZZI, Cesare. Appropriazione Indebita, in Enciclopedia del Diritto, vol. II, Varese, Giuffrè, 1958, p. 845. "L'appropriazione indebita è reato instantâneo, che si consuma con il manifestarsi della volontà di signoria assoluta sulla cosa" (tradução nossa).

${ }^{155}$ Idem. p. 845 “(...) con il compimento do detti atti, anche se il termine fissato per la restituizione non è ancora scaduto" (tradução nossa).

${ }^{156}$ Idem. Ibidem. "(...) la consumazione coincide con lo scadere del termine entro il quale l'atto docuto si doveva compiere" (tradução nossa).

${ }^{157}$ Idem. Ibidem. “(...) data la peculiare struttura di questa fattispecie criminosa, sembra assai difficile, per non dire impossibile, configurare un'ipotesi di tentativo. La condotta esteriore, infatti, ha unicamente la funzione di manifestare il mutato atteggiamento del soggetto nei confronti della cosa, la sopravvenuta volontà di dominio" (tradução nossa).

${ }^{158}$ Idem. Ibidem. "(...) il semplice fatto di offrire in vendita la cosa basta a dar vita a un'appropriazione consumata, anche se il reo non trovi acquirenti”' (tradução nossa).
} 
Com isso, fecham-se, por completo, as portas para o reconhecimento da tentativa do delito.

Em sentido semelhante, mais recentemente, Giovanni Fiandaca e Enzo Musco defendem que "o crime se consuma com a realização externa de um dos comportamentos idôneos a exprimir a vontade de apropriação definitiva"159 e advertem com razão que, por vezes, "para verificar a existência de uma vontade tendente a tornar própria a coisa, de maneira duradoura, pode ser indispensável também ter em consideração circunstâncias sucessivas à realização do fato". 160

Para Fiandaca e Musco, que claramente aderem à ideia subjetivista, "em todo caso, há de se excluir que a consumação do crime pressuponha, como se se tratasse de um crime de resultado, a efetiva aquisição de uma duradoura senhoria sobre a coisa: é suficiente a realização de uma conduta que aponte expressamente, de maneira objetivamente reconhecível, a vontade de alcançar um domínio definitivo". ${ }^{161}$

No mesmo sentido, na jurisprudência italiana, a Corte de Cassação atesta que a consumação do crime de apropriação indébita "liga-se a todo comportamento objetivamente excedente da esfera de faculdades contidas no título de posse e incompatíveis com o direito do proprietário, assim o crime de apropriação indébita se aperfeiçoa no tempo e no lugar no qual a sociedade locatária de um bem realiza mesmo os atos de disposição, e não no que diz

\footnotetext{
159 FiandacA, Giovanni; Musco, Enzo, Diritto Penale - Parte Speciale - I Delitti contro il Patrimonio, vol. II, T. 2, Bologna, Zanichelli, 2011, p. 113. "Il reato si consuma con la realizzazione esterna di uno dei comportamenti idonei a esprimere la volontá di appropriazione definitiva" (tradução nossa).

${ }^{160}$ Idem. Ibidem. “(...) per accertare l'esistenza di un volere tendente a far propria la cosa in maniera durevole, può essere in questi casi indispensabile prendere in considerazione circonstanze anche "sucessive" alla realizzazione del fatto" (tradução nossa).

${ }^{161}$ Idem. Ibidem. "(...) in ogni caso, è da escludere che la consumazione del reato presupponga, come se si trattasse di un reato di "evento", l'effettiva acquisizione di una duratura signoria sulla cosa: è sufficiente, piuttosto, la realizzazione di una condotta che appalesi apunto, in maniera objettivamente riconoscibile, la volontá di conseguire un definitivo domínio" (tradução nossa).
} 
respeito ao momento e ao local em que deveria haver sucessiva restituição do bem". 162

No que diz respeito à tentativa do delito, Fiandaca e Musco, um pouco mais reservados, limitam-se a apontar a controvérsia no Direito italiano, embora possa-se aferir que não a admitem.

Nesse sentido, destacam que aqueles que admitem a tentativa de apropriação indébita no Direito italiano limitam-se a reconhecê-la "naqueles casos em que os atos realizados sejam idôneos e unívocos, mas não constituam, ainda, uma 'verdadeira' apropriação (como, por exemplo, expor à venda um objeto ou escrever um endosso de um título)" "163 ressalvando desde logo a dificuldade de se estabelecer quando se estará diante da referida "verdadeira apropriação".

Com o que, apontam os autores italianos, que "se se compartilha a tese que identifica a consumação com a realização de um ato já idôneo a manifestar uma vontade de apropriação definitiva, a configuração da tentativa remanesce como uma hipótese teórica destinada a encontrar pouco reflexo na realidade", ${ }^{164}$ o que bem parece revelar as ideias subjetivistas sobre o tema.

Fica evidente, diante do exposto, a consolidação da mais tradicional doutrina italiana no sentido de atribuição de natureza formal ao delito de apropriação indébita, negando-lhe a possibilidade de tentativa ou limitando-a às raras condutas plurissubsistentes.

\footnotetext{
162 Cass. 11 luglio 2002, in CED Cass. 222657: “(...) si connette ad ogni comportamento oggettivamente eccedente la sfera delle facoltà ricomprese nel titolo del possesso ed incompatibile con il diritto del proprietário, sicché il reato di appropriazione indébita si perfeziona nel tempo e nel luogo in cui la società locatária di un bene compie sul medesimo atti di disposizione e non giá con riguardo AL momento e al luogo in cui debba avvenire la sucessiva restituizione del bene" (tradução nossa).

${ }^{163}$ FiANDACA, Giovanni, MuSCO, Enzo, op. cit., p. 114. “(...) a quelle ipotesi (ad esempio esporre in vendita un oggetto, scrivere una dichiarazione di girata su un titolo) in cui gli atti compiuti siano idonei e univoci, ma non costituiscano ancora una vera appropriazione" (tradução nossa).

${ }^{164}$ Idem. Ibidem. "(...) se si condivide la tesi che identifica la consumazione con la realizzazione di un atto già idôneo a manifestare una volontà di appropriazione definitiva, la configurabilità del tentativo rimane un'ipotesi teórica destinada a trovare poço riscontro nella realtà" (tradução nossa).
} 
Esse entendimento, de tão arraigado naquela cultura jurídica, acaba por influenciar até mesmo aqueles autores que parecem se aproximar da natureza material do delito ao questionar a importância sobrevalorizada que é comumente atribuída ao elemento subjetivo do tipo na economia do delito.

É o que se passa, por exemplo, com Francesco Antolisei. Corretamente, o autor italiano entende que, se a obtenção de um proveito não é necessária à consumação da apropriação indébita, isso, de outro lado, não permite imaginar que uma simples mudança no animus do possuidor - mais precisamente, "a decisão de começar a possuir uti dominus"165 — possa ser suficiente para caracterizar a consumação. Assim, para Antolisei, não se pode considerar consumado o crime de apropriação indébita com a mera mudança no animus do agente, pela óbvia razão de que "por regra geral, que não admite exceção, um fato puramente psíquico não pode, por si só, produzir efeitos jurídicos, sendo sempre necessário que este se reflita em um comportamento exterior". ${ }^{166} \mathrm{O}$ problema no raciocínio de Antolisei é que, em seguida, ele acaba por reconhecer a possibilidade de tentativa com fundamento exclusivamente na plurissubsistência da conduta (o que representa uma concessão à lógica do crime formal), e não por afirmar com clareza (já que não é claro nesse particular) a possibilidade de que, esgotada a conduta (uni ou plurissubsistente), o resultado não se realize por circunstância alheia à vontade do agente (o que verdadeiramente caracterizaria o crime material) ${ }^{167}$.

\footnotetext{
${ }^{165}$ Antolisei, Francesco, Manuale di Diritto Penale, vol. 1, Milano, Giuffrè, 1994, p. 355: “(...) la decisione di cominciare a possedere uti dominus" (tradução nossa).

${ }^{166}$ Idem. Ibidem: “(...) per regola generale che non ammete eccezioni, un fatto puramente psichico non può mai, di per sé solo, produre effetti giuridici, essendo sempre necessário Che Esso si rifletta in un comportamento esteriore" (tradução nossa).

${ }^{167}$ Idem, p. 356: Quanto à tentativa, Antolisei reconhece que a doutrina prevalecente no direito italiano nega a sua possibilidade, por tratar-se, segundo a maioria, de um delito unissubsistente, mas considera de todo arbitrário asseverar que o delito em questão sempre se aperfeiçoe num único ato, pois pode acontecer de este se realizar por meio de uma multiplicidade de atos, devendo-se reconhecer a tentativa, por exemplo, no caso "do indivíduo que seja surpreendido no decorrer da venda de um coisa havida em depósito" ("dell'individuo che venga colto mentre sta per vendere una cosa avuta in deposito").
} 
Tal situação, de arraigada concepção formal da estrutura do delito de apropriação indébita, também parece guiar a doutrina brasileira, em que pese sua tradicional afirmação, unânime e contraditória, de que a apropriação indébita é crime material, que, no entanto, só admitiria tentativa quando se trata de conduta plurissubsistente.

Nesse sentido, se o que importa é a forma como se trata o tipo penal em sua interpretação concreta, não resta dúvida de que, ao negar a tentativa de apropriação indébita ou limitá-la de forma severa, de modo a evidenciar a visão de que o ato apropriativo é antes de tudo a manifestação de um animus domini em si suficiente à caracterização do delito, nada mais fazem a doutrina e a jurisprudência brasileiras que lhe atribuir o caráter formal, tal como a mais tradicional doutrina italiana.

Diante do exposto, mais importante que revelar, como revelada está, a contradição terminológica da doutrina brasileira, é aferir se a natureza formal atribuída implicitamente pela doutrina nacional, e de forma mais explicita pela doutrina italiana, ao delito de apropriação indébita, realmente encontra correspondência na realidade subjacente ao tipo penal, e portanto, se parte dos desajustes da doutrina e jurisprudência brasileiras não se devem, em verdade, mais a essa questão de fundo que àquele equívoco de linguagem.

Em outras palavras, resta investigar, como essência do presente trabalho, se não é possível encontrar solução diversa para a conturbada questão da tentativa, que, mais atenta à realidade da estrutura típica do delito de apropriação indébita, permita diferenciar em termos de consumação e, portanto, punição, as condutas que produzem lesões concretas ao bem jurídico protegido daquelas que não as produzem.

É o que se passa a fazer com a análise da aplicação dos princípios da lesividade e da materialidade ao delito de apropriação indébita: buscar desvelar a estrutura subjacente ao seu tipo penal e identificar de que forma 
as considerações sobre o bem jurídico protegido pelo tipo penal podem guiar o raciocínio interpretativo em busca da solução justa.

\subsection{A relação entre tipo subjetivo e tipo objetivo no delito de apropriação indébita: a apropriação como pensamento e ação.}

Diante da acentuada interdependência entre os elementos essenciais do tipo penal de apropriação indébita, a dificultar sobremaneira a exata compreensão da economia do delito, deu-se, como visto, no Brasil, ainda em maior medida que na Itália, o fenômeno da sobrevalorização do elemento subjetivo do tipo, como se o delito pudesse se dar essencialmente pela transfiguração do pensamento, da qual a ação seria mera revelação.

Ocorre que, embora bem estabelecida a importância de se verificar a presença do elemento subjetivo do tipo para a configuração do delito de apropriação indébita, há que se destacar, com ênfase, a impossibilidade de se atribuir ao animus rem sibi habendi o distorcido papel que, por vezes, lhe tem sido dado.

Para tanto, deve-se compreender inicialmente que o próprio fundamento das ideias de lesividade ou ofensividade e materialidade no Direito Penal, aplicado à espécie, bem demonstra a ilegitimidade de se conceber que a apropriação possa ser, exclusiva ou preponderantemente, um fenômeno do pensamento.

Nesse sentido, Nilo Batista destaca, desde logo, em sua obra introdutória ao Direito Penal brasileiro, que "à conduta puramente interna, ou puramente individual — seja pecaminosa, imoral, escandalosa ou diferente - 
falta a lesividade que pode legitimar a intervenção penal", ${ }^{168}$ restando claro que “as ideias e convicções, os desejos, aspirações e sentimentos dos homens não podem constituir o fundamento de um tipo penal, nem mesmo quando se orientem para a prática de um crime". ${ }^{169}$

Mantovani, de outro lado, ensina que "somente pode ser considerado crime "o comportamento humano material e extrinsecamente realizado no mundo exterior e, portanto, munido de corporiedade e, por consequência, perceptível pelos sentidos: o fato material é a base primeira e imprescindível de todo desvalor penal, pedra angular do crime". ${ }^{170}$

Aliás, parece que a absoluta necessidade de estabelecimento de uma base real, concreta, da qual se possa aferir, com segurança, o desvalor penal, constitui uma das razões do esforço de Miguel Reale Júnior para consolidar na cultura jurídica brasileira a ideia da antijuridicidade material.

Se, como bem destaca Miguel Reale Júnior, "a antijuridicidade não é algo que se acrescenta ao fato através de um juízo de valor", e se "a ação ao se realizar já é antijurídica, por se efetuar em contraposição aos valores impostos pelo Direito", não se pode conceber que possa ser considerado crime, pensamento ou ação à qual falte, no plano concreto, o caráter potencialmente lesivo aos bens da vida, que lhe empresta o próprio sentido. ${ }^{171}$ Como não se poderia, também como tão bem exposto pelo mestre do Largo de São Francisco - conceber, ao contrário, a punição dos atos humanos aos quais faltasse o necessário elemento subjetivo. Essa a essência lógica e, mais do que tudo, o conteúdo programático da estrutura típica a partir do finalismo e, vale dizer, bem colocada no próprio art. 18 do Código Penal.

\footnotetext{
${ }^{168}$ BAtista, Nilo, Introdução Crítica ao Direito Penal Brasileiro, $10^{\mathrm{a}}$ ed., Rio de Janeiro, Revan, 2005 , p. 91.

${ }^{169}$ BATISTA, Nilo, op. cit., p. 91.

${ }^{170}$ Mantovani, Ferrando, Diritto Penale - Parte Generale, $7^{\mathrm{a}}$ ed., Padova, CEDAM, 2011, p. 121 “(...) il comportamento umano materialmente estrinsecantesi nel mondo esteriore e, perciò, munito di una sua coporeità e, quindi, percepibili dai sensi: il fatto materiale è la base prima e imprescindibile di ogni giudizio di disvalore penale, pietra angolare del reato" (tradução nossa).

${ }^{171}$ ReAle Junior, Miguel, Teoria do Delito, $2^{\mathrm{a}}$ ed., São Paulo, Revista dos Tribunais, 2000, p. 86.
} 
A sabedoria, mais uma vez, parece estar na ideia mediatriz do caminho central: é imprescindível garantir o equilíbrio entre os elementos típicos reveladores do desvalor da ação, o que, na apropriação indébita, significa compreender que não há uma separação real entre o elemento subjetivo e os elementos objetivos, cujos significados somente podem ser alcançados pela análise conjunta e equilibrada de suas invariáveis elementares.

Daí porque adverte Antolisei, com precaução, que se a obtenção de um proveito não é necessária à consumação da apropriação indébita, também não se pode advogar que uma mudança no animus do possuidor ("a decisão de começar a possuir uti dominus", ${ }^{172}$ como especifica) seja suficiente para caracterizar a consumação do crime.

Nesse ponto, como já dito, destaca o professor italiano que a razão pela qual o crime de apropriação indébita não se pode considerar consumado com a mera mudança no animus do agente é óbvia: "por regra geral, que não admite exceção, um fato puramente psíquico não pode, por si só, produzir efeitos jurídicos, sendo sempre necessário que este se reflita em um comportamento exterior". ${ }^{173}$

No mesmo sentido, assevera Mantovani que, para que haja conduta típica, é preciso "não apenas a mudança no animus (isto é, a vontade de ter a coisa não mais nomine alieno, mas como própria)" mas também "a manifestação da mesma em ato externo de senhoria, pelo que se apropriar é se comportar em relação à coisa como se fosse própria". ${ }^{174}$

\footnotetext{
${ }^{172}$ ANTOLISEI, Francesco, op. cit., p. 355: “(...) la decisione di cominciare a possedere uti dominus” (tradução nossa).

${ }^{173}$ Idem. p. 815: “(...) per regola generale che non ammete eccezioni, un fatto puramente psichico non può mai, di per sé solo, produre effetti giuridici, essendo sempre necessário che esso si rifletta in un comportamento esteriore" (tradução nossa).

${ }^{174}$ Mantovani, Ferrando, Diritto Penale - Parte Speciale II - Delitti contro il Patrimonio, $4^{\mathrm{a}}$ ed., Padova, CEDAM, 2012, p. 116: “(...) non soltanto il mutamento dell'animus (cioè la volontà di tenere la cosa non più nomine alieno ma come propria). Ma, altresì, la estrinsecazione dello stesso in atti esterni di signoria, per cui appropriarsi è comportarsi verso la cosa como se fosse própria" (tradução nossa).
} 
Afinal, a materialidade do fato reside, como bem observa Fragoso, "em apropriar-se o agente da coisa, no todo ou em parte, isto é, dela assenhorar-se; em fazê-la própria; em praticar sobre ela atos de disposição, como proprietário. A apropriação não é apenas um momento subjetivo, sendo indispensável fato exterior que constitua ato de domínio e revele o propósito de apropriar-se". ${ }^{175}$

Não bastassem tais considerações de natureza estrutural, é de se verificar, ainda, que o critério exclusivamente psicológico ou subjetivista é absolutamente inadequado também quanto à necessidade de segurança jurídica, na medida em que leva o Direito para o campo do imponderável, envolvendo-o no mistério próprio dos recônditos do pensamento.

Desnecessário dizer que, por sua própria natureza, tal critério psicológico é absolutamente inseguro também por tratar-se o pensamento de fenômeno reversível, fluído, de prova absolutamente diabólica. Os atuais estudos sobre a questão do dolo apontam nesse sentido. Autores pós-finalistas chegam a propor certa normatização do elemento volitivo, superando a situação do elemento subjetivo como estado meramente mental. ${ }^{176}$ Após passar em revista inúmeros autores, entre ele Roxin, Hassemer, Herzeberg e Puppe, na Alemanha, e Ragués I Valles, na Espanha, José Carlos Porciúncula questiona se a determinação do dolo com base na ação do autor não se mostraria como um juízo arbitrário. Sua resposta é plenamente negativa. A interdependência entre os conceitos subjetivo e objetivo estaria, pois, absolutamente estabelecida. Segundo seu pensamento, o único modo de dissolver a confusão estabelecida entre as considerações objetivas e subjetivas - tão presentes ao longo da historiografia da avaliação do dolo - estaria na compreensão de que os elementos subjetivos não constituem entidades psicologicamente reais situados em um fórum internum do

\footnotetext{
${ }^{175}$ Fragoso, Heleno Claudio, Lições de Direito Penal, 4a ed., São Paulo, José Bushatsky, 1978, p. 46. ${ }^{176}$ Cf. PÉrez BARberÁ, Gabriel, El Dolo Eventual - Hacia el Abandono de la Idea de Dolo como Estado Mental, Buenos Aires, Hammurabi, 2011, pp. 471 e ss.
} 
indivíduo. Evidentemente, continua Porciúncula, isto também seria válido para os conhecimentos especiais do autor. Eles não seriam vistos como processos que ocorrem no fundo de sua alma, mas como momentos da ação, componentes que são de um sentido exteriorizado. Seria, pois, justamente através de manifestações externas que se poderia averiguar a bagagem de conhecimento do autor. Dessa forma, seriam as manifestações externas que proporcionam os critérios para a atribuição dos estados mentais de terceiros. ${ }^{177}$

É preciso, então, como tarefa preliminar, de certa obviedade, mas não menos importante no presente trabalho, e por todas as razões já apontadas, desmistificar a questão do papel do elemento subjetivo do tipo penal de apropriação indébita e dizer, com todas as letras, que, embora central na compreensão do delito, a denominada inversão no ânimo da posse não pode ser vista como a própria ação típica em sua essência.

Diante do que, já se deve indicar, ainda que em seu primeiro passo, que, para que haja apropriação indébita, é preciso que haja uma ação inequívoca de apropriação no mundo natural, concreto, com aptidão de lesão à propriedade do bem cuja posse foi confiada ao agente.

Tal postulado, é preciso deixar claro, não vale somente para a situação, pouquíssimo frequente (por razões práticas de impossibilidade de exploração do pensamento), na qual se pretenda punir tão somente o pensamento (quando este vem revelado em um diário por exemplo). Há que se descartar, também, a sua versão mais sutil, e por isso mais perigosa, na qual se poderia tentar atribuir à ação típica um papel secundário, de mera revelação do elemento subjetivo do tipo, este sim de importância central e suficiente à caracterização do delito.

\footnotetext{
${ }^{177}$ PORCIÚNCULA, José Carlos, La Exteriorización de lo Interno - Sobre la Relación entre lo Objetivo y lo Subjetivo en el Tipo Penal, Tese apresentada à Universidade de Barcelona, 2013, p. 435.
} 
Em outras palavras é preciso ver a apropriação indébita, em uma primeira aproximação, como a conjugação inseparável do pensamento com a ação.

\subsection{Tutela penal da propriedade e legitimidade do Direito Penal: a questão do bem jurídico protegido pelo tipo penal de apropriação indébita.}

Descartada, por completo, a possibilidade de que a apropriação indébita, de alguma forma, se aperfeiçoe tão somente ou fundamentalmente com o surgimento do animus rem sibi habendi e devidamente esclarecidas quais são as ações típicas que podem configurar a execução do tipo penal, há que se verificar, por derradeiro, a estrutura típica e a economia do delito, para precisar, com segurança, o momento consumativo da apropriação indébita e, por consequência, aferir a possibilidade ou a impossibilidade de tentativa do delito.

Para tanto, porém, é preciso compreender a questão do bem jurídico protegido pelo tipo penal de apropriação indébita, sem o que não se poderia bem depreender a estrutura do crime, pela ausência de um dos seus elementos fundamentais.

É de se notar, então, que existe ampla divagação científica sobre a construção do que se pode chamar de Direito Penal patrimonial. Isso se torna muito mais evidente quando se verifica, na atualidade, toda a discussão levada a cabo por autores como Klaus Tiedmann, ${ }^{178}$ que entendem uma vinculação deste com o baldado Direito Penal econômico. É, no entanto, com vistas a preocupações mais preliminares que se verifica toda uma sorte de problemas ainda não bem desvendados pela ciência jurídica.

\footnotetext{
${ }^{178}$ Cf. Tiedmann, Klaus, Poder Económico y Delito - Introducción al Derecho Penal Económico y de la Empresa, trad. Amélia Mantilla Villegas, Barcelona, Ariel, 1985, pp. 10 e ss.
} 
Dentre tantos, a questão da apropriação indébita guarda espaço de relevo. Urge, assim, em termos preliminares em seu estudo, saber sua real abrangência, para questionar-se o seu real problema.

\subsubsection{Interesses patrimoniais e Direito Penal}

Existem diferentes formas de intelecção do problema penal patrimonial. Pode-se pretender traçar as mais diversas formas de classificação da questão, como o fazem, por exemplo, Quintano Ripolles, que as segmenta, entre outras, em infrações de apoderamento lucrativo de patrimônio alheio (casos de fraude), infrações de uso abusivo do próprio patrimônio (casos de insolvências e negócios ilícitos), infrações reguladas em leis especiais etc. ${ }^{179}$ Fundamental mostra-se, no entanto, a observação de Bajo Fernandez, para quem o esforço por classificar os delitos patrimoniais não compensaria a pouca utilidade dos resultados obtidos, ${ }^{180}$ quanto mais em uma realidade como a brasileira, a qual passa, muitas vezes, ao largo de discussões desse jaez.

Por certo o debate científico urge alguma prospecção, tanto em termos de questões materiais como da própria sistemática do bem jurídico tutelado, principalmente com o escopo de se pretender estabelecer os alcances e os momentos de legitimidade do crime de apropriação indébita, bastante vilipendiados na leitura atual.

Justamente por essa razão existe uma compreensão doutrinária no sentido de oferecer uma classificação que permita, dentro de um espectro amplo de delitos patrimoniais, diferenciar diferentes grupos de crimes em função do bem jurídico protegido e dos distintos elementos típicos que concorrem a cada

\footnotetext{
${ }^{179}$ Cf. Quintero RIPOLlÉS, Antonio, Tratado de la Parte Especial del Derecho Penal - Infracciones Patrimoniales de Apoderamento, T. II, Madrid, Civitas, 1977, pp. 22 e ss.

${ }^{180}$ BAjo FernandeZ, Miguel, Manual de Derecho Penal - Parte General - Delitos Patrimoniales y Económicos, T. II, Madrid, Ceura, 1987, p. 14.
} 
um deles. Essa, aliás, a própria lógica do Código Penal ao ofertar uma divisão em títulos e capítulos. ${ }^{181}$

\section{Diferentemente de outros países, a discussão nacional não se} foca, necessariamente, em termos da distinção protetiva entre propriedade e patrimônio. ${ }^{182}$ É bem verdade que a grande maioria da doutrina internacional entende que a tutela do Direito Penal patrimonial diga respeito, sim, ao patrimônio, e não à propriedade. Isso teria por efeito decorrencial o fato de que, para haver crime dessa ordem, o objeto em questão deveria ter valor econômico.

${ }^{181}$ De la Mata Barranco, Norberto J., Tutela Penal de la Propiedad y Delitos de Apropiación - El Dinero como Objeto Material de los Delitos de Hurto y Apropiación Indebida, Barcelona, PPU, S.A., 1994, p. 57.

182 Apenas a título ilustrativo, compete, aqui, a menção de Vives Antón e González Cussac sobre a precisão do sentido de patrimônio na realidade penal espanhola - próxima que é da brasileira -, sendo que "ha de señalarse la existencia, tradicionalmente, de tres concepciones diferentes del patrimonio, a saber: la jurídica, la económica y la económica-jurídica (mixta). En la actualidad, y siguiendo a la doctrina mayoritaria alemana, se ha expuesto el llamado concepto personal o funcional del patrimonio (Zugaldía; Sánchez Tomás; De La Mata Barranco). El concepto jurídico de patrimonio se entiende integrado por el concepto de derechos patrimoniales de una persona. Una tal concepción, como ha destacado en la doctrina española Huerta Tocildo, comporta un circulo vicioso: la dificultad de ofrecer un concepto de patrimonio se soslaya mediante la referencia a los derechos patrimoniales; pero, el problema no se resuelve, puesto que subsiste la dificultad de determinar qué derechos han de ser calificados de ese modo. La principal objeción que cabe oponer al concepto jurídico de patrimonio reside en que, debería entonces entenderse que el objeto de protección de los delitos comprendidos en el Titulo XIII incluye la perdida de bienes o derechos sin valor económico y con ello ampliar desmesuradamente el concepto típico de perjuicio patrimonial. De tal suerte, habría que estimar que comete estafa el que, mediante engaño, obtiene una cosa a cambio de contraprestación del mismo valor. Obviamente, no es ese el sentido que el perjuicio patrimonial reviste en los distintos delitos contra la propiedad. El concepto económico de patrimonio atiende al poder fáctico del sujeto y al valor económico de los bienes o situaciones. Desde este punto de vista, el patrimonio podría definirse como conjunto de valores económicos de los que, de hecho, dispone una persona. Ciertamente, el concepto económico de patrimonio no incurre en las dificultades apuntadas respecto del concepto jurídico; pero, a su vez, suscita otras nuevas. Si se aceptase como válido a efectos penales, implicaría en ciertos casos, el otorgamiento de protección penal a posiciones patrimoniales ilegítimas (v.gr. drogas ilegales, armas prohibidas, obras de arte sustraídas, etc.). El Derecho penal entraría, así, en conflicto con otras ramas del ordenamiento, lo que resulta absolutamente inaceptable dada la unidad básica de este, a la que ya se ha hecho referencia. Se ha sostenido por algunos autores (Bockmann, Otto) una concepción personal y funcional del patrimonio, que parte de su condición de instrumento de realización de la personalidad y, desde una perspectiva subjetiva del individuo, lo vincula más que a su valor económico, a la idea de utilidad como satisfacción de necesidades o persecución de fines del individuo (Asúa Batarrita). En consecuencia sobrevalora el daño subjetivo que pueden producir las diversas conductas lesivas. Y, nuestro Código atiende, ante todo, al dato objetivo del valor económico, por lo que resulta útil como criterio único, pues además su aceptación supondría una ampliación extraordinaria de la intervención del Derecho penal (cfr. García Arán). En resumen, parece necesario optar por un concepto mixto económico-jurídico de patrimonio. Una tal concepción implica la limitación de los bienes y derechos patrimoniales a los económicamente valorables y exige, por otra parte, que sean poseídos por el sujeto en virtud de una relación reconocida por el ordenamiento jurídico". Vives Antón, Tomás S., GonzÁlez CuSSAC, José L., Delitos Contra el Patrimonio y el Orden Socioeconómico - (I) Introducción General, in VIVES ANTÓn, Tomás S., Ors BerEnGUER, Enrique, CARbonell Mateu, Juan Carlos, GonzÁles Cussac, José Luis, Martínez-BujÁn PÉrez, Carlos, Derecho Penal - Parte Especial, Valencia, Tirant lo Blanch, 2010, pp. 353 e ss. 
Assim, por exemplo, Zulgadía Espinar, ao mencionar o fato de que o entendimento penal acerca do tema difere do sentido jurídico-privado, já que, sob esse entendimento, seria paradoxal a compreensão de certos delitos como o da apropriação indébita - em que o proprietário de determinada coisa pudesse vir a ser apenado ao se apropriar de algo seu cuja tutela estivesse com outro. ${ }^{183}$ Seria isso um delito contra a propriedade? Por certo que não. Entretanto, e isso é inegável, em muitas situações mais cotidianas, o que se verifica é, ainda considerando o caso da apropriação indébita, que um terceiro, de posse de determinado bem alheio faça uso deste como se seu fora. ${ }^{184}$

Francisco Muñoz Conde caminha nesse sentido ao afirmar que, no que toca à apropriação indébita, deve-se ter por certo que o seu resultado consiste na apropriação, a qual se manifesta na realização de atos de disposição ou, ainda, na negativa de terceiro de haver recebido coisas sob sua guarda e, por conseguinte, na percepção de prejuízo por parte do titular do direito em relação à devolução ou na entrega de tais bens. Dessa forma, continua, a apropriação e o prejuízo geralmente coincidem, mas não necessariamente, já que se pode estar diante da figura da tentativa. ${ }^{185}$ Em proximidade, também está Mantovani, ao recordar a apropriação de coisas fungíveis, em que se dá a restituição de coisa em igual gênero e quantidade. ${ }^{186}$

Cabem, pois, algumas distinções. Sob uma visão clássica, Binding tinha por certo que o conceito jurídico de patrimônio dizia respeito aos valores que são reconhecidos como direitos patrimoniais subjetivos pelo Direito privado ou pelo Direito público (conceito jurídico de patrimônio). Essa

\footnotetext{
${ }^{183}$ Zugaldía EsPinAR, José Miguel, Delitos contra la Propiedad y el Patrimonio, Madrid, Akal, 1988 , pp. 11 e ss.

${ }^{184}$ Código Penal brasileiro, art. 168: “Apropriar-se de coisa alheia móvel, de que tem a posse ou detenção. Pena - reclusão, de um a quatro anos, e multa. $\S 1^{\circ}$ - A pena é aumentada de um terço, quando o agente recebeu a coisa: I- em depósito necessário; II- na qualidade de tutor, curador, síndico, liquidatário, inventariante, testamenteiro ou depositário judicial; III- em razão de ofício, emprego ou profissão.

${ }^{185}$ Cf. Muñoz Conde, Francisco, Derecho Penal - Parte Especial, Valencia, Tirant lo Blanch, 2009, pp. 413 e ss.

${ }^{186}$ Mantovani, Ferrando, Diritto Penale - Parte Speciale II - Delitti contro il Patrimonio, $4^{\mathrm{a}}$ ed., Padova, CEDAM, 2012, pp. 119 e ss.
} 
concepção privatista das relações entre o Direito Civil e o Direito Penal, de cunho estritamente pancivilista, no qual a seara penal assumia um papel meramente dependente e secundário, acabava por deixar vastas perguntas não respondidas e vazios de punibilidade. Por outro lado, não se pode tampouco ter-se por correta a percepção de que o patrimônio estaria ancorado unicamente em valores econômicos, expressos monetariamente (conceito econômico de patrimônio). Essa visão, dominante na Alemanha, é, por igual, bastante criticada, já que existem inúmeras situações em que se pode verificar um crime contra a propriedade (ou patrimônio), ainda que não seja possível dimensionar os valores e prejuízos sofridos pela vítima. ${ }^{187}$

Como busca de solução entre ambos os quadrantes, formatouse o que se compreende por conceito jurídico-econômico de patrimônio (conceito misto). Para esta, haveria uma limitação da proteção dos bens patrimoniais aos bens detentores de valor econômico, desde que vinculados a uma posse decorrente de relação jurídica. Fariam, pois, parte do patrimônio de determinada pessoa, a soma dos bens com valores econômicos postos à disposição de alguém sob a proteção do ordenamento jurídico. ${ }^{188}$ Como bem destacam Vives Anton e González Cussac, tal concepção implicaria, por derradeiro, em uma limitação de bens e direitos patrimoniais àqueles economicamente dimensionáveis, exigindose que seus titulares sejam dotados de vínculos estabelecidos em uma relação jurídica. $^{189}$

A discussão não é nova. Na Itália, o Código Zanardelli, de 1889, mencionava capitularmente os "crimes contra a propriedade". O Código Rocco, como o brasileiro, substituiu a tutela para "crimes contra o patrimônio", atentando, para além de uma visão puramente econômica, à intersecção jurídicoeconômica. O mesmo, diga-se, deu-se na Espanha, onde, até o advento do Código Penal de 1995, tutelava-se a propriedade. Depois do novo código, o patrimônio. Mesmo assim, ainda hoje, existem grandes dúvidas sob o real estado da questão.

${ }^{187}$ Cf. ZUGALdía Espinar, José Miguel, op. cit., pp. 54 e ss.

${ }^{188}$ Idem, p. 56.

${ }^{189}$ VIVES ANTÓN, Tomás S., GonZÁlez CusSAC, José L., op. cit., p. 354. 
De fato, a colocação posta, ainda que genericamente correta, parece claudicar em relação à apropriação indébita propriamente dita. Embora seja certo que a construção do Direito Penal Patrimonial seja originalmente fincada no foco propriedade-patrimônio, e que isso acaba por derivar a questões como o conceito jurídico-econômico do patrimônio, hão de existir situações em que o ideário de proteção - e tutela — não se vê colocado de forma tão simples. Na realidade, o que se percebe é que na construção da apropriação indébita existe uma situação para além da questão patrimonial. Cuida-se, também, de um dever de tutela assumido pelo possuidor (transitório) do bem. Nesse sentido, o crime de apropriação indébita acaba por se mostrar pluriofensivo.

Cumpre recordar que Fiandaca e Musco caminham nesse passo ao mencionarem que os crimes vistos no mencionado título "crimes contra o patrimônio" nem sempre têm o patrimônio como bem jurídico exclusivo. Em figuras como extorsão, extorsão mediante sequestro ou determinadas situações de roubo também protege-se a liberdade individual. ${ }^{190}$ Note-se que a construção típica nacional evidencia duas órbitas distintas. A primeira versa sobre o patrimônio propriamente dito; a segunda, contudo, diz respeito ao dever de responsabilidade quanto à restituição assumido pelo detentor precário da coisa. Embora isso seja evidente no art. $168, \S 1^{\circ}$, do Código Penal, quando é estabelecida uma causa de aumento de pena de um terço se o agente recebeu a coisa em depósito necessário; na qualidade de tutor, curador, síndico, liquidatário, inventariante, testamenteiro ou depositário judicial; ou, ainda, se recebeu-a em razão de oficio, emprego ou profissão, o mesmo se dá em relação ao caput do artigo. Neste não existe um dever de responsabilidade de restituição em função do estado (nos casos previstos no art. $168, \S 1^{\circ}$, I e II, CP, em situações de fiel depositário, tutor, curador, síndico, liquidatário, inventariante e testamenteiro). Existe, contudo, uma responsabilidade obrigacional de devolução do bem (art.

\footnotetext{
${ }^{190}$ FIANDACA, Giovanni, MuSCO, Enzo, Diritto Penale - Parte Speciale, vol. II, Milano, Zanichelli, 2002, p. 11.
} 
168, caput, CP), que pode até mesmo ser majorada em casos de relação profissional (art. $\left.168, \S 1^{\circ}, \mathrm{III}, \mathrm{CP}\right) .{ }^{191}$

Situação similar é encontrada no caso de peculato (art. 312, $\mathrm{CP})$, no qual se verifica um crime nitidamente patrimonial, que também ataca um dever de responsabilidade, que, no caso, ao versar sobre a administração pública, acaba por impingir uma modificação no próprio objeto central de tutela. $\mathrm{O}$ crime (pluriofensivo) deixa de ser considerado patrimonial e passa a ser tido como funcional.

No caso da apropriação indébita, apesar de a estrutura típica ainda enquadrar-se no espectro dos crimes patrimoniais, é de se perceber que tem ele um plus em sua dimensão de cuidado. Isso explica, portanto, por que não se pode afirmar unicamente pelo tratamento patrimonial em seu raio de ação. Há que se ter em conta a violação do dever de tutela por parte do agente e a violação da liberdade de disposição patrimonial da vítima ${ }^{192}$.

A colocação de Fiandaca e Musco é também nesse sentido. Para os autores italianos, podem ser identificadas duas grades categorias nos crimes considerados patrimoniais: crimes contra a propriedade (patrimônio em sentido lato) e crimes contra o patrimônio em sentido estrito. No primeiro grupo, abarcando furto, apropriação indébita, dano etc., o objeto de tutela é constituído

\footnotetext{
${ }^{191}$ Código Penal brasileiro, art. 168: "Apropriar-se de coisa alheia móvel, de que tem a posse ou detenção. Pena - reclusão, de um a quatro anos, e multa. $\S 1^{\circ}$ - A pena é aumentada de um terço, quando o agente recebeu a coisa: I- em depósito necessário; II- na qualidade de tutor, curador, síndico, liquidatário, inventariante, testamenteiro ou depositário judicial; III- em razão de ofício, emprego ou profissão.Jescheck e Weigend afirmam, a seu turno, que o patrimônio não é protegido no Direito Penal frente a qualquer agressão, mas só a determinadas formas de agressão que se mostrem especialmente perigosas. Seriam os casos do prejuízo patrimonial dado mediante engano, na fraude; por meio de violência, na extorsão; mediante abuso de confiança, na apropriação indébita. No caso, há de se verificar tanto o desvalor da ação como do resultado. JESCHECK, Hans-Heinrich, WeIGend, Thomas, Tratado de Derecho Penal - Parte General, trad. Miguel Olmedo Cardenete, Granada, Comares, 2002, p. 257.

${ }^{192}$ Para Edgard Magalhães Noronha, é interessante notar, em exemplo ao contrário, afirma que o direito de propriedade não é objeto jurídico exclusivo na apropriação indébita. $\mathrm{O}$ autor dá como exemplo o credor pignoratício, que confia a coisa a terceiro para guardar, e este apropria-se da coisa, entregando-a ao proprietário. Neste caso, diz Noronha, não houve ofensa ao direito do proprietário, mas ocorreu uma lesão patrimonial ao credor, pois este ficou sem a garantia sobre a qual tinha um

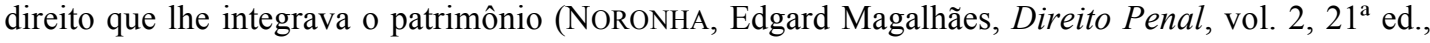
São Paulo, Saraiva, 1986. p. 327.).
} 
pelo poder do titular do direito de propriedade sobre a coisa individualmente determinada. No segundo grupo (estelionato, extorsão etc.), o princípio é menos formal e mais material, já que se entende o patrimônio como entidade econômica complexa que requer necessariamente um dano patrimonial. ${ }^{193}$ Ainda que existam inegáveis esforços no sentido de unificar a compreensão, a dificuldade é significativa.

No mesmo caminho, segue Zugaldia Espinar ao destacar que "um erro muito difundido na doutrina espanhola é o de considerar os delitos de dano, apropriação indébita e furto como delitos patrimoniais em sentido estrito, o que conduz a aplicar-lhes um conceito - o de patrimônio - que nasce e se desenvolve para as necessidades e exigências do delito de estelionato, conduzindo a resultados materialmente injustos e político-criminalmente absurdos na sua aplicação aos já mencionados delitos de dano, apropriação indébita e furto". ${ }^{194}$

Para amparar sua afirmação, Zugaldía Espinar serve-se de três exemplos que vale a pena transcrever, na medida em que revelam as graves distorções daquela determinada visão sobre a questão patrimonial no Direito Penal:

a) "X subtrai a $\mathrm{Z}$ uma velha fotografia de um antepassado em comum. Se se afirma que o objeto material de um delito contra o patrimônio - e se sustenta que o furto o é [o mesmo se aplicando, por identidade de razões, à apropriação indébita] — não podem ser aqueles bens que estejam dotados

\footnotetext{
${ }^{193}$ FiandaCA, Giovanni, Musco, Enzo, Diritto Penale - Parte Speciale, vol. II, Milano, Zanichelli, 2002, pp. 4 e ss.

${ }^{194}$ ZUGALDía EsPinAR, José Miguel, op. cit., p. 24: “(...) un error muy difundido en la doctrina española como es el de considerar a los delitos de daños, apropiación indebida y hurto como estrictos delitos patrimoniales, lo que conduce a aplicarles sin más un concepto - el de patrimonio - que nace e se desarrolla por y para las necesidades y exigencias del delito de estafa, conduciendo a resultados materialmente injustos y político-criminalmente absurdos su aplicación a los ya mencionados delitos de daños, apropiación indebida y hurto" (tradução nossa).
} 
somente de valor afetivo ou sentimental, haveria de concluir que $\mathrm{X}$, no caso do exemplo, não comete qualquer delito." ${ }^{\prime 195}$

b) "X subtrai a $Z$ um livro, deixando em seu lugar outro de equivalente valor. Se se afirma que neste caso não se pode entender ter causado um prejuízo patrimonial (já que o prejuízo não consiste na perda do poder de disposição sobre uma coisa concreta, mas em uma perda econômica) a sua qualificação por furto estará descartada, não só neste caso como em todas as demais hipóteses em que se possa falar de compensação."196

c) "X herdou de seu marido um quadro pintado por este: como o defunto carecia de talento artístico, o quadro não tem qualquer valor monetário. $Z$, por ódio à $X$, destrói o quadro. Nesta hipótese, $Z$ não cometeria delito algum porque o delito de dano exige - afirma-se - que a coisa danificada tenha algum valor patrimonial economicamente valorável - exigência lógica de considerar o delito de dano como um delito contra o patrimônio". ${ }^{197}$

Com o que, de forma absolutamente pertinente, o professor espanhol direciona suas críticas à dicção espanhola do tipo penal de apropriação indébita, destacando que ela nos coloca diante de proposições "que produzem um grande vazio de proteção ao direito de propriedade (enquanto se subordina dita proteção a que a coisa, propriedade de alguém, tenha valor econômico) e conduzem pura e simplesmente à legalização das vendas forçadas (convertendo o

\footnotetext{
${ }^{195}$ Idem, p. 25: "X sustrae a $Z$ una vieja fotografía de un antepasado común. Si se afirma que objeto material de un delito contra el patrimonio - y se sostiene que el hurto lo és - no pueden serlo aquellos bienes que estén dotados solo de valor afectivo o sentimental, habría que concluir que X, en el caso del ejemplo, no comete delito alguno" (tradução nossa).

${ }^{196}$ Idem. Ibidem: "X sustrae a $Z$ un libro, dejando en su lugar otro de equivalente valor. Si se afirma que en este caso no puede entenderse causado un perjuicio patrimonial (ya que el perjuicio no consiste en la pérdida del poder de disposición sobre una cosa concreta, sino en una pérdida económica) la calificación por hurto quedará descartada, no solo en El, sino también en todos los demás supuestos en los que quepa hablar de compensación" (tradução nossa).

${ }^{197}$ Idem. Ibidem, p. 25: "X ha heredado de su esposo un cuadro pintado por este: como el difunto carecía de talento artístico, el cuadro no tiene ningún valor monetario. Z, por odio hacia $X$, destruye el cuadro. En este supuesto $\mathrm{Z}$ no cometería delito alguno porque el delito de daños exige - se afirma que la cosa dañada tenga algún valor patrimonial económicamente valorable - exigencia lógica de considerar al delito de daños como un delito contra el patrimonio" (tradução nossa).
} 
Direito Penal espanhol em um dos ordenamentos jurídicos mais raros do mundo)". 198

Assim, resta considerar que, no que toca à apropriação indébita, não se deve simplesmente considerar aplicável a esta o conceito jurídico-econômico (misto) de patrimônio. Explica-se: não se trata de um crime unicamente patrimonial. Cuida-se, também, de outra dimensão de tutela, o que acaba por consagrá-lo como um delito patrimonial sui generis. Seriam construções próximas às desenvolvidas por autores como Rudolphi e Maiwald.

Para Rudolphi, a essência dos crimes de apropriação encontrase no prejuízo que sofre a propriedade, especificamente em relação à posição de poder que formalmente ostenta o proprietário. Mas, adverte, isso não significa que cada ataque à propriedade signifique, necessariamente, um dano à mesma. Isso só ocorreria quando se reduz o poder de domínio que surge da propriedade sobre a coisa, que se associa à relação jurídica estabelecida entre uma pessoa e um bem, de igual forma que as faculdades de domínio a serem exercidas pelo proprietário. As possibilidades de utilização de um bem, pois, constituem a relação de propriedade. E estas, sem dúvida, seriam as que mais claramente se veriam abaladas em ocorrência da apropriação indébita. ${ }^{199}$

Já Maiwald esclarece que na apropriação indébita, na qual o desvalor estaria radicado na lesão à propriedade alheia, deve-se determinar quando e como seria a propriedade lesionada. Essa constatação de lesão seria perceptível quando constatada uma oposição à vontade do titular da propriedade ou, ainda, havendo uma contrariedade à livre decisão do proprietário na utilização de seus bens. Isso se mostraria correto, segundo o autor, pois o ser humano seria

\footnotetext{
198 Idem. Ibidem, p. 25: "Frente a este tipo de construcciones - que producen un alto vacio de protección del derecho de propiedad (en cuanto se subordina dicha protección a que la cosa propiedad de alguien tenga valor económico) y conducen lisa e llanamente a la legalización de las ventas forzadas (convirtiendo al Derecho Penal español en uno de los ordenamientos jurídicos más raros del mundo" (tradução nossa).

${ }^{199}$ Cf. De la Mata BARRANCO, Norberto J., op. cit., pp. 77 e ss.
} 
pessoa espiritualmente autônoma, que necessita de esfera de atuação própria e que somente sua vontade poderia determinar sua autorrealização. ${ }^{200}$

Sendo tida como adequada a consideração de que o crime de apropriação indébita é multifacetado, sui generis em sua constituição e que não se vincula a ele o conceito jurídico-penal de patrimônio, não se pode dizer, por equivocado, que nele se dispõe de aspectos da propriedade e de como esta é exercida. Dir-se-ia, dessa forma, que a especificidade da apropriação indébita a aproxima muito mais da relação pancivilista da propriedade, e não, consoante a grande maioria dos crimes a ela próximos, do patrimônio (ou do conceito jurídico-econômico de patrimônio).

É de se notar que algumas legislações, como é o caso da espanhola, pretenderam resolver esse problema mencionando explicitamente a necessidade de monetarização da coisa a ser indevidamente apropriada, no caso, com valores superiores a quatrocentos euros (art. 252, CP espanhol ${ }^{201}$ ). Situações

\footnotetext{
${ }^{200}$ Idem, op. cit., 78 e ss.

201 Artículo 252 - Serán castigados con las penas del artículo 249 ó 250, en su caso, los que en perjuicio de otro se apropiaren o distrajeren dinero, efectos, valores o cualquier otra cosa mueble o activo patrimonial que hayan recibido en depósito, comisión o administración, o por otro título que produzca obligación de entregarlos o devolverlos, o negaren haberlos recibido, cuando la cuantía de lo apropiado exceda de cuatrocientos euros. Dicha pena se impondrá en su mitad superior en el caso de depósito necesario o miserable.

Artículo 249 - Los reos de estafa serán castigados con la pena de prisión de seis meses a tres años, si la cuantía de lo defraudado excediere de 400 euros. Para la fijación de la pena se tendrá en cuenta el importe de lo defraudado, el quebranto económico causado al perjudicado, las relaciones entre éste y el defraudador, los medios empleados por éste y cuantas otras circunstancias sirvan para valorar la gravedad de la infracción.

Artículo 250. 1. El delito de estafa será castigado con las penas de prisión de un año a seis años y multa de seis a doce meses, cuando:

1. Recaiga sobre cosas de primera necesidad, viviendas u otros bienes de reconocida utilidad social.

2. Se perpetre abusando de firma de otro, o sustrayendo, ocultando o inutilizando, en todo o en parte, algún proceso, expediente, protocolo o documento público u oficial de cualquier clase.

3. Recaiga sobre bienes que integren el patrimonio artístico, histórico, cultural o científico.

4. Revista especial gravedad, atendiendo a la entidad del perjuicio y a la situación económica en que deje a la víctima o a su familia.

5. Cuando el valor de la defraudación supere los 50.000 euros.

6. Se cometa abuso de las relaciones personales existentes entre víctima y defraudador, o aproveche éste su credibilidad empresarial o profesional.

7. Se cometa estafa procesal. Incurren en la misma los que, en un procedimiento judicial de cualquier clase, manipularen las pruebas en que pretendieran fundar sus alegaciones o emplearen otro fraude procesal análogo, provocando error en el Juez o Tribunal y llevándole a dictar una resolución que perjudique los intereses económicos de la otra parte o de un tercero.

8. Si concurrieran las circunstancias $4^{\mathrm{a}}, 5^{\mathrm{a}}$ o $6^{\mathrm{a}}$ con la $1^{\mathrm{a}}$ del número anterior, se impondrán las penas de prisión de cuatro a ocho años y multa de doce a veinticuatro meses.
} 
em que a avaliação se mostrasse abaixo desse valor seriam, pois, atípicas. Resta claro, assim, que bens de valor emocional, ou ao menos não quantificáveis no mencionado patamar, se submetidas à espoliação, não guardariam dignidade penal. A conduta de sua indevida apropriação seria atípica.

A legislação brasileira não faz essa ressalva, o que se mostra adequado. Por óbvio um bem de valor sentimental também faz parte do patrimônio de alguém. E do patrimônio com dignidade penal, pois não é de se admitir que possa ser ele simplesmente retirado do domínio de uma pessoa contra a sua vontade. Se isso é intuitivo no que diz respeito a uma consideração genérica dos crimes patrimoniais em sentido lato, muito mais evidente se mostra quando se fala da apropriação indébita.

De se imaginar um cidadão religioso que possua uma relíquia de determinado santo católico, que não possui valor de mercado pela própria doutrina da Igreja, sendo proibida sua venda consoante o Código de Direito Canônico ("Sacras reliquias vendere nefas est" - art. 1.190). Essa pessoa entrega a relíquia a um seu colega de congregação, o qual se responsabiliza por guardá-la. Em momento posterior dá-se a recusa na devolução da coisa. O simples fato de não existir um valor econômico a ser estipulado para a relíquia não pode excluí-la da proteção penal, ainda mais em face de um tipo penal mais aberto como o brasileiro. Tem-se aqui, sim, caso de violação à propriedade, ou, ao menos, ao exercício desta.

Parece claro, assim, que o bem jurídico aqui tratado, sob qualquer que seja o ponto de vista examinado, há de proteger o direito quanto ao exercício da vontade do titular da propriedade ou, como se mencionou, à livre decisão do proprietário na utilização do bem. A expectativa do titular em relação ao usufruto do bem seria o que Günther Jakobs tão bem caracterizou como sendo a finalidade de regulamentação penal. ${ }^{202}$ Muito embora aqui não se siga a linha do

\footnotetext{
202 JAKOBS, Günther, Derecho penal - Parte general, trad. Joaquin Cuello Contreras, Jose Luis Serrano Gonzalez de Murillo, Madrid, MarcialPons, 1997, pp. 225 e ss.
} 
pensamento Jakobsiano, ele é bem claro ao afirmar o crime como contrariedade ao direito. Von Liszt já informava que não é o ordenamento jurídico que cria um determinado interesse, mas, sim, a vida. A proteção jurídica, então, eleva um dado interesse vital à condição de bem jurídico. ${ }^{203}$ Pois bem, note-se que também neste aspecto, que depois redunda na constatação de funções a serem atribuídas ao bem jurídico, também justifica-se a constatação de que deve ser valorada a liberdade do proprietário. Daí se falar que a consideração aqui posta diz respeito não só a uma proteção relativa ao bem em si mas também à responsabilidade daquele que teve sob sua guarda, em confiança, tal bem.

Essa construção pode parecer equivocada ou, no mínimo, um tanto inusual, mas não o é. Como se sabe, existem delitos que representam ataques ao patrimônio em sua totalidade (universitas iuris) ou de meros elementos que o compõem. ${ }^{204}$ Não se ignora que exista uma íntima relação entre propriedade e patrimônio, e isso é expresso no que se poderia entender por delitos exclusivamente patrimoniais. Não é, contudo, o caso da apropriação indébita. Nela há de se perceber variações que a pospõe sobre as luzes do que se poderia entender sobre a disponibilidade da propriedade — não necessariamente sob um angulo econômico. ${ }^{205}$

\footnotetext{
${ }^{203}$ LiSZT, Franz Von, Tratado de Direito Penal Allemão, 5, §3 I 1.

${ }^{204}$ VIVES ANTÓN, Tomás S., GONZÁlEZ CUSSAC, José L., op. cit., p. 354.

205 No mesmo sentido, é interessante notar que o conceito de disposição patrimonial também é adequado à explicação da consumação do crime de extorsão. Giuseppe Ragno afirma que o verdadeiro ponto central do tipo de extorsão é dado justamente por essa subespécie de liberdade individual, tendo em vista que "a idoneidade da conduta e a relação de causalidade devem ser determinadas sobre a base e nos limites daquela constrição psíquica penalmente relevante da qual resulta a respectiva ofensa, e se a sucessiva indagação sobre a existência dos dois elementos posteriores - dano e vantagem - deve ser conduzida sobre o pressuposto do confronto de uma constrição eficaz para os fins penais específicos (RAGNO, Giuseppe, Il Delito di Estorsione, Milano, Giuffrè, 1966, p. 78-79: "Se idoneità della condotta e rapporto di causalità debbono essere accertati sulla base e nei limiti di quella costrizione psichica penalmente rilevante di cui risulta la sua offesa e la successiva indagine sulla esistenza degli ulteriori due elementi - danno e profitto - deve essere condotta sul presupposto del riscontro di una costrizione valida ai fini penali specifici”. (tradução nossa)). Em outras palavras, entende-se que entre a liberdade moral (considerada genericamente) e a ofensa ao patrimônio, a ligação faz-se justamente por esse conceito de liberdade de disposição patrimonial, já que o maior ou menor grau desta é que revelará a eficácia concreta que tiveram a violência ou a grave ameaça e, depois, os efeitos patrimoniais que se possam imputar como consequência da constrição realizada (cf. GOMES JÚnior, João Florêncio de Salles, O Crime de Extorsão no Direito Penal Brasileiro, São Paulo, Quartier Latin, 2012).
} 
Isso não quer dizer, no entanto, que a questão patrimonial não possa ter influência na compreensão da conduta em concreto e no deslinde de certos problemas práticos. Se é verdade que o tipo penal de apropriação indébita visa tutelar a propriedade, e não o patrimônio, no sentido já desenvolvido no presente trabalho, também é verdade que a tutela da propriedade não se pode dar sem um sentido a lhe emprestar dignidade.

Assim, é imperioso destacar que a tutela da propriedade se dá como meio de proteção de valores caros à humanidade, a merecerem tutela penal, como o próprio patrimônio, os sentimentos relacionados à família, aos mortos e à pátria (nos casos de bens de valor sentimental) ou mesmo o sentimento religioso, em tudo digno de tutela penal (como no caso de apropriação indébita de relíquias religiosas). De tal forma, deve-se notar, por absolutamente fundamental, que, ausente no caso concreto qualquer valor a ser tutelado além do valor patrimonial da coisa, e sendo este de ínfima importância, nada obsta, a prudente aplicação do princípio da insignificância como boa medida de política criminal.

\subsubsection{Objeto material, resultado típico e bem jurídico}

A discussão sobre o conceito material do delito é velha como a Sé de Braga ou, nas palavras de Ricardo Robles Planas, antiga como o Direito Penal. ${ }^{206}$ No esforço de estabelecer condições de limitar a atividade do poder punitivo do Estado, muito se perquire. A busca do que venha a ser um injusto culpável é, pois, perseguida, ainda que com mais vagar, desde o abandono de uma leitura puramente positivista da norma.

Alguns pontos preliminares são cruciais na tentativa de alcançar um Direito Penal legítimo. Entender o que venha a ser uma compreensão ideal — e não meramente positivada — do tipo criminal da apropriação indébita requer, dessa forma, uma análise mais extensiva do que normalmente se faz. Esse

\footnotetext{
${ }^{206}$ Robles Planas, Ricardo, Dogmática de los Limites al Derecho Penal, in HirSCH, Andrew Von, Seelmann, Kurt, Wohlers, Wolfgang, Robles Planas, Ricardo (ed.), Limites al Derecho Penal Principios Operativos en la Fundamentación del Castigo, Barcelona, Atelier, 2012, p. 19.
} 
é o sentido da lição de Hans-Heinrich Jescheck e de Thomas Weigend, segundo os quais o conceito de delito da dogmática clássica serviu de base à distinção entre uma visão puramente objetiva do injusto e uma culpabilidade nitidamente subjetiva. A antijuridicidade era valorada unicamente em função da situação causada pelo fato. Entrementes, continuam os autores, o avanço da teoria do delito permitiu o vislumbre de que a antijuridicidade não se esgota na desaprovação do resultado delitivo, mas também deve ser incluída no juízo de desvalor uma situação relativa à ação e ao resultado. ${ }^{207}$

Günther Stratenwerth menciona que uma posição crítica em relação à lei penal pode ser vista na procura de limitação desta, a partir da Constituição. Seriam os deveres de penalização existentes na Lei Maior que permitiram a real busca de legitimidade penal. Além destes, e talvez com maior ênfase, há de se buscar a legitimidade com vistas ao princípio de proporcionalidade, o qual também se mostra derivado da regra constitucional. ${ }^{208}$ Com ele, destacam-se as naturezas fragmentárias e subsidiárias do Direito Penal. Por essa razão é que alguns autores afirmam que, produzida a infração de uma dada norma, constata-se a presença de um dano, que é precisamente aquilo que justificaria a sanção penal. ${ }^{209}$

De outro lado, não se pode dizer presente um conceito único de bem jurídico, ainda que se pretenda entendê-lo como alicerce do Direito lastreado em um mínimo ético, ${ }^{210}$ como já ponderou Welzel. Atualmente, autores como Jäger, Giorgio Marinucci e Emilio Dolcini entendem por adequada a menção de que bens jurídicos podem enquadrar-se como situações de fato permeadas de valor, que podem ser modificadas e que, assim, podem ser tuteladas contra tais modificações ${ }^{211}$. Seriam, pois, situações de fato, modificáveis e tuteláveis, em uma aproximação à própria construção de Miguel Reale sobre fato-valor-norma,

\footnotetext{
${ }^{207}$ JESCHECK, Hans-Heinrich, WEIGEND, Thomas, op. cit., p. 256.

208 Stratenwerth, Günther, Derecho Penal. Parte General - El Hecho Punible, trad. Manuel Cancio Meliá e Marcelo Sancinetti, Madrid, Civitas, 2005, pp. 61.

${ }^{209}$ Robles Planas, Ricardo, op. cit., p. 27.

${ }^{210}$ Cf. STRATENWERTH, Günther, op. cit., pp. 54 e ss.

${ }^{211}$ MarinuCCI, Giorgio, Dolcini, Emilio, Corso di Diritto Penale, vol.1, Milano, Giuffrè, 1999, p. 294.
} 
como dado fundamental sobre a natureza do fenômeno jurídico.

A ideia de crime como ofensa a um bem jurídico tem longa data, chegando a aperfeiçoar a construção de que o crime seria apenas o fato que o ordenamento jurídico acaba por reconhecer merecedor de uma sanção penal. Não se trata, com isso, de um dever violado, ${ }^{212}$ mas, sim, de uma baliza ao Direito Penal. Como esclarecem Eugenio Zaffaroni, Alejandro Alagia e Alejandro Slokar, o bem jurídico é um conceito indispensável para tornar efetivo o princípio de lesividade, mas não é, de modo algum, um conceito legitimante do poder punitivo. Daí a impossibilidade de confusão entre uso limitativo do conceito de bem jurídico e seu uso legitimante, tão frequentemente verificada. ${ }^{213} \mathrm{Em}$ suma, seria de se ter o bem jurídico como um valor abstrato de ordem social protegido juridicamente, ${ }^{214}$ o que implica no cumprimento de determinadas funções, ainda que sem uma melhor definição temática na sua faixa de atuação. ${ }^{215}$

Dessa forma, apesar de ser correto afirmar que nem toda a conflituosidade típica requer diretamente uma lesão a um determinado bem jurídico, esta, entretanto, é pressuposta. Não se olvida, aqui, a presença de teorias negatórias da utilidade do bem jurídico ou mesmo da sua capacidade de rendimento, como o fazem, entre outros, Jakobs. Aqui, contudo, defende-se a emergência da utilização do bem jurídico como alicerce à construção penal, até mesmo como um elemento de limitação do poder do Estado em relação a tantas e tantas incidências prejudiciais que podem ser percebidas.

Observe-se, todavia, que, na realidade, o Código Penal, em cada um dos seus tipos penais, não se presta tão somente a tutelar, separada e exclusivamente, o patrimônio ou a propriedade. Ainda que o Código Penal brasileiro mencione em seu título "Dos crimes contra o patrimônio", a proteção

\footnotetext{
212 Cf. ANTOLISEI, Francesco, op. cit, pp. 162 e ss.

${ }^{213}$ ZAFFARONi, Eugênio Raúl, PIERANGELI, José Henrique, Manual de Direito Penal Brasileiro, São Paulo, Revista dos Tribunais, 2001, pp. 463 e ss.

${ }^{214}$ JesCHECK, Hans-Heinrich, WeIGEND, Thomas, op. cit., p. 275.

${ }^{215}$ Cf. Polaino Navarrete, Miguel, El Injusto en la Teoría del Delito, Corrientes, MAVE, 2000, pp. 337 e ss.
} 
dada versa sobre o patrimônio e a propriedade, sendo bifronte e ambivalente. Conforme seja o caso, estar-se-á mais perto de uma ou de outra situação. Dessa forma, restaria a indagação vestibular sobre o momento da consumação do crime de apropriação indébita. Este o cenário de fundo da tese posta. Antes dessa divagação, porém, faz-se necessária uma avaliação sobre as próprias qualidades dos tipos penais.

Para fins analíticos, três categorias de delitos, entre outras, podem ser elencadas: delitos de intenção (nos quais se estabelece a exigência de uma orientação subjetiva até uma finalidade concreta); delitos mutilados em dois atos (representados por tipos intencionais em que uma ação dolosa é realizada pelo sujeito ativo como meio executivo para alcançar um fim constituído por uma posterior ação do próprio autor); delitos de resultado cortado (em que, conforme a natureza dos delitos de intenção, o injusto se fundamenta em uma finalidade que o sujeito pretenda conseguir com a mera realização de uma conduta). ${ }^{216}$ Nesse último caso, estariam as situações em que as intenções de lucro, proveito e favorecimento, tão importantes à realidade patrimonial, são bastantes presentes. A ideia de lucro inescapavelmente associa-se à questão da apropriação indébita. ${ }^{217}$ Ao lado destes, no entanto, encontrar-se-iam os delitos nos quais se verifica a intencionalidade de prejuízo alheio ou, ainda, de ânimo "lucro e prejuízo", em que incidem ao mesmo tempo situações correlatas. ${ }^{218}$ Pois bem, seria de se admitir que o crime de apropriação indébita condiciona estas duas variáveis ou lhe bastaria a noção fundamental de lucro? A apropriação indébita torna crime a apropriação de coisa alheia de que o agente tem prévia posse ou detenção, imaginando, assim, o apoderamento do bem ao acervo pessoal do agente. Em suma, ao assenhorear-se de bem indevidamente, existe um inegável aumento no leque de bens a ele disponíveis. Mas não só.

Como se viu - e aqui se assume como correto - Maiwald dispõe sobre o crime como sendo uma modalidade de tolhimento do exercício das

\footnotetext{
${ }^{216}$ Idem, pp. 137 e ss.

${ }^{217}$ Idem, p. 161.

${ }^{218}$ Idem, pp. 169 e ss.
} 
faculdades de disposição da propriedade alheia. Logo, imagina-se também, ainda que em sentido lato, um prejuízo à vítima (não necessariamente monetário, ainda que normalmente o seja). Essas considerações, no entanto, lastreiam-se todas numa percepção argentária e quantificável, no viés econômico da propriedade (ou, ao menos, o conceito patrimonial jurídico-econômico). Isso distancia-se da percepção exposta. Não são apenas coisas com fundo monetário aquelas com proteção penal, quanto mais em relação ao crime de apropriação indébita. Imagine-se situação para além da foto ou de bem nitidamente de fundo sentimental sugeridas por Zugaldía Espinar. Em se tratando de objeto sabidamente sem valor de mercado, mas único, irreparável e que traz recordações de pessoa falecida, a apropriação deste traz prejuízos ao exercício das faculdades de propriedade de seu titular, devendo, por isso, ser também tutelado. Se é assim, há de se entender que o mote do crime em espécie não é o lucro assenhoramento - ou lucro e prejuízo e lucro. Não se trata de lucro, pois no tolhimento das faculdades de propriedade pode se dar, além de tudo, a própria destruição do bem. Aqui, convém recordar a diferença nuclear entre o crime de dano e o crime de furto. Em ambos há o perdimento de bem por parte do seu titular. Entrementes, a reprovação do furto é sensivelmente maior devido, exatamente, ao resultante lucro obtido pelo agente. Esse diferenciador, calcado na consumação do crime, aqui não é tão perceptível.

Não se diz que o lucro por parte do agente seja fundamental no crime de apropriação, pois nele existem situações prévias, já mencionadas, como as situações de confiança a que é alçado o agente. Previamente lhe é outorgada a responsabilidade de zelar por determinado bem. Ao abusar e violar o dever de confiança, ele acaba violando múltipla situação de tutela e, ao mesmo tempo, incidindo no princípio da especialidade. Assim, seria de se dizer que em uma ocorrência em que se verifique a assunção de responsabilidade no cuidar de determinado bem atribuído por seu titular a um terceiro - relação de confiança - havendo o concreto tolhimento da faculdade e exercício de domínio do legítimo titular da propriedade, estaria consumado o crime. Situações posteriores, como a de destruição do bem, seriam unicamente causas justificáveis de aumento 
de pena dentro da moldura penal do próprio tipo do art. 168 do Código Penal.

\subsection{Estrutura típica e economia do delito: a apropriação como ação e como resultado}

Compreendida a questão do bem jurídico protegido pelo tipo penal de apropriação indébita, é preciso notar que a detida análise da estrutura típica da conduta também revela-nos a mesma realidade, na qual se exige, em conformidade com uma matriz de causa e efeito, resultado típico lesivo à propriedade para a consumação do delito.

O núcleo típico da conduta é apropriar-se. Como é de meridiana clareza, apropriar-se pressupõe não só a existência de uma coisa como que esta seja de outrem, o que nos leva à exigência, que ora importa ao raciocínio, que à apropriação do autor, como causa, deve corresponder, como efeito, uma expropriação da vítima para que se dê por aperfeiçoado o delito.

Nesse sentido, concorrendo dois significados complementares no verbo empregado, e sendo de rigor que a linguagem busque reproduzir o mundo dos fatos, pode-se e deve-se pensar a estrutura típica de apropriação, em sua realidade concreta, sob um duplo aspecto: apropriar-se é, de um lado, tornar seu (ainda que ilegitimamente) o que é do outro e, de outro lado, é causar a desapropriação da vítima, que deixa de poder exercer os seus legítimos poderes, inerentes ao domínio.

Nesse sentido, note-se que, com muita precisão, De la Mata Barranco destaca a conduta do resultado ao afirmar que "o conceito de apropriação pode referir-se tanto ao resultado típico como à conduta dos delitos de furto e apropriação indébita. Como resultado típico constitui um elemento do tipo objetivo dos delitos de apropriação que reflete o processo de incorporação patrimonial no âmbito de domínio do sujeito ativo. Como conduta, refere-se à 
dinâmica comissiva, de apoderamento ou apropriação, que produz materialmente dita incorporação". ${ }^{219}$

De outro lado, o mesmo autor também é capaz de, com bastante percuciência, perceber o duplo significado do próprio resultado típico ao asseverar que "a apropriação em sentido estrito (Aneignung) faz referência ao aspecto positivo do resultado típico apropriação. Para que esse elemento concorra, é suficiente uma utilização temporária da coisa, sempre que com ela pretenda-se uma incorporação, ao menos momentânea, ao patrimônio do sujeito ativo", 220 enquanto "a expropriação (Enteignung) implica privação definitiva ou duradoura ao sujeito passivo das faculdades que derivam da sua condição de proprietário". 221

Com o que se pode verificar a possibilidade de, realizadas e esgotadas todas as ações do possuidor, com as quais manifesta seu intento de apropriar-se da coisa alheia, a expropriação não venha a se dar, como, por exemplo, no caso em que, efetuada a venda do bem possuído pela internet ou por telefone e recebido o preço, o agente deixe o bem à disposição do comprador na portaria de seu prédio, que, no entanto, instado pelo legítimo proprietário, entrega-o a quem de direito.

Não há, portanto, como atribuir natureza formal ao delito de apropriação indébita. Não se trata, é bom dizer, tão somente da alegada tentativa, possível nos crimes formais, relacionadas à conduta plurissubsistente. No exemplo elencado, que certamente vale por todos, não há mais conduta a ser

\footnotetext{
${ }^{219}$ De la MATA BARRANCO, Norberto J., op. cit., p.128: "El concepto de apropiación puede venir referido tanto al resultado típico como a la conducta de los delitos de hurto y apropiación indebida. Como resultado típico constituye un elemento del tipo objetivo de los delitos de apropiación que refleja el proceso de incorporación patrimonial al ámbito de dominio del sujeto activo. Como conducta refiere la dinámica comisiva, de apoderamiento o apropiación, que produce materialmente dicha incorporación" (tradução nossa).

${ }^{220}$ Idem. p. 147: "La apropiación en sentido estricto (Aneignung) hace referencia al aspecto positivo del resultado típico apropiación. Para que este elemento concurra es suficiente una utilización temporal de la cosa, siempre que con Ella se pretenda una incorporación siquiera momentánea al patrimonio del sujeto activo" (tradução nossa).

${ }^{221}$ Idem. p. 149: "La expropiación (Enteignung) implica privación definitiva o duradera al sujeto pasivo de las facultades que se derivan de su condición de propietario" (tradução nossa).
} 
realizada pelo agente, que, aliás, já satisfez inclusive o seu intento patrimonial, mas o resultado lesivo à propriedade não se verifica por circunstância alheia à vontade do agente, o que bem demonstra não se tratar de crime formal.

Nos crimes formais, como destaca Reale Júnior, 222 “não há evento destacado da ação, pois a descrição da proibição incriminada cinge-se à conduta, sendo que o resultado coincide com esta, sem menção no tipo penal dos eventuais resultados decorrentes da ação praticada ou omitida". Dessa forma, a distinção "entre os crimes formais e materiais está no tipo, pois há tipos que não mencionam o resultado, como os formais, ao contrário de outros que o fazem, como os materiais, de ação e evento."

O que ocorre no crime de apropriação indébita tem outra natureza. Não se pode confundir a alta freqüência com a qual há a imediata produção do resultado típico com a afirmação da natureza formal do delito. Fosse assim, poder-se-ia afirmar, forçando um pouco a pena, que também seria formal o delito de homicídio quando praticado por pelotões de fuzilamento.

Embora se reconheça que o acentuado intrincamento entre a ação (consumo, disposição, retenção) e o resultado (lesão ao direito de propriedade, com obstáculo ao exercício dos poderes inerentes ao domínio) na economia do delito e a frequente instantaneidade com que este sucede àquela nos casos concretos gerem impressionante tendência de direcionamento do pensamento à hipótese do crime formal (como na mais tradicional doutrina italiana), tem-se que tal caracterização constitui equívoco capaz de distorcer a solução de boa parte das questões concretas relacionadas a esse crime.

Ao se ignorar, na solução do caso concreto, a natureza material do delito e impedir ou restringir a tentativa por critérios equivocados e excessivamente estreitos, acaba-se por gerar a injustiça própria da desproporção e a insegurança jurídica dos estados de confusão conceitual. É o que acontece na

${ }^{222}$ ReAle JÚNIOR, Miguel, Instituições de Direito Penal, Rio de Janeiro, Forense, 2002, p.269. 
doutrina brasileira, que apenas nominalmente admite a natureza material do delito de apropriação indébita.

Basta pensar, por exemplo, na evidente injustiça de se reconhecer o crime consumado nos casos em que não há lesão à propriedade ou, mais precisamente, àquela liberdade de disposição patrimonial, consistente na possibilidade de exercício desembaraçado dos poderes próprios do domínio. Aceitar a imposição de crime consumado no caso proposto de venda feita por internet ou telefone, de objeto que acaba não sendo entregue ao comprador, mas, sim, por engano ou graças à intervenção de alguém, ao seu legítimo proprietário, levaria a aplicação de pena integral a caso concreto no qual não há qualquer resultado lesivo à propriedade, o que poderia significar, de outro lado, e de forma perigosa, a aceitação de uma concepção na qual bastaria, para fundamentar e legitimar a pena, a mera desobediência à norma ou a afirmação da necessidade de proteção da sua vigência.

Assim, embora em outros crimes o resultado apareça mais claramente destacado da ação, como no homicídio, e em outros se façam necessários alguns simples esclarecimentos, como no caso da extorsão, tratada muito equivocadamente como crime formal, na apropriação indébita, ainda que de modo mais sutil, o mesmo fenômeno pode ser reconhecido, de forma a caracterizá-lo como crime material. ${ }^{223}$

Tal postulado fica mais evidente se se compreende que o resultado lesivo à propriedade, para além da sua realidade fática, também se refere a um resultado jurídico que a qualifica, relativo à violação da liberdade de

\footnotetext{
${ }^{223}$ É interessante notar, aliás, com Miguel Reale Júnior, que se pode afirmar um certo caráter material até mesmo em crimes indiscutivelmente formais como a concussão ao dizer que "[...] nos crimes formais, em que o resultado coincide com a ação também é impossível a tentativa. Eventualmente, um crime formal pode realizar-se por meio de um iter, por exemplo, na hipótese do crime de concussão executado por exigência feita por escrito que venha a ser interceptada antes de chegar ao destinatário, no qual deveria provocar o medo da autoridade. Neste caso, difícil de ocorrer pois dificilmente o agente documentaria a exigência, o crime deixa de ser formal, para ser material, o resultado destacando-se da ação.” (REALE JÚNIOR, Miguel, op. cit., 2002. p. 292).
} 
disposição sobre a coisa, também capaz de induzir a afirmação de materialidade do crime, na medida em que não se pode olvidar que esse fenômeno jurídico também está dotado de concretude suficiente à afirmação de sua existência real na comunidade humana. Com o que, também se pode afirmar ser o crime de apropriação indébita delito de natureza material sob esse outro aspecto.

\subsection{Consumação e tentativa de apropriação indébita no Direito Penal brasileiro.}

Diante do exposto, se é verdade que o bem jurídico protegido - a propriedade - pode ser imediatamente violado pela ação típica, não é menos verdade que isso nem sempre ocorre, o que bem diz sobre a natureza material do delito em questão e a consequente admissibilidade, de forma ampla e natural, da tentativa do delito. Corretamente estabelecida a natureza material do crime de apropriação indébita, não há maior dificuldade na resolução das questões relacionadas à tentativa.

Como sempre acontece nos crimes materiais, haverá, portanto, tentativa punível de apropriação indébita sempre que, após a realização de conduta apta a produzir o resultado lesivo à propriedade, este não se verificar por circunstância alheia à vontade do agente.

Isso porque, como já destacado no estudo da estrutura típica

deste crime, De la Mata Barranco nos informa que "a apropriação, enquanto resultado típico dos delitos de apropriação, é um elemento normativo do tipo, que possui uma função autônoma especialmente importante para a captação do conteúdo do injusto destes delitos. A privação, o 'tomar' a coisa, pertence, pelo contrário, ao processo de comissão ou execução do delito e faz referência ao deslocamento físico do objeto tomado: é, neste sentido, um elemento puramente 
descritivo. Aquele aspecto da apropriação se relaciona com o conceito de propriedade; este, com o conceito de posse". ${ }^{224}$

Ainda segundo De la Mata Barranco, na Alemanha "insiste-se nesta questão, não mais para destacar a diferença entre furto e apropriação indébita, senão a que existe entre um processo físico e outro valorativo, ou, dito de outro modo, entre um elemento descritivo (Wegnahme) e outro normativo (Zueignung) - elementos que se desenvolvem, respectivamente, nos âmbitos externo e interno da atividade do sujeito - , diferença partir da qual se capta a verdadeira essência do injusto destes delitos". 225

Daí porque se pode afirmar que o resultado típico da apropriação indébita ocorre com a vulneração do direito de propriedade sobre a coisa, o que ocorre, por sua vez, quando o proprietário se vê impedido de exercer os poderes inerentes ao domínio, em razão da imposição de obstáculos concretos pelo sujeito ativo da apropriação indébita. Este é, portanto, o momento consumativo do delito em questão.

Assim, embora a questão da tentativa naturalmente possa levar a inúmeras discussões de grande relevância em seu aspecto geral, no que concerne à apropriação indébita, pouco mais tem esse delito de peculiar quanto ao conatus, em que pese ser mais comum que à ação corresponda imediatamente um resultado a consumar o crime, consistente na alteração do plano fático, que passa a contar com um obstáculo, anteriormente inexistente, ao exercício dos poderes inerentes ao domínio por parte do legítimo proprietário.

\footnotetext{
${ }^{224}$ DE LA MATA BARRANCO, Norberto J., op. cit., p. 128. "La apropiación, en cuanto resultado típico de los delitos de apropiación, ES un elemento normativo del tipo, que posee una función autónoma especialmente importante para la captación del contenido del injusto de estos delitos. La privación, el "tomar" la cosa, pertenece, por el contrario, al proceso de comisión o ejecución del delito y hace referencia al desplazamiento físico del objeto tomado: es, en este sentido, un elemento puramente descriptivo. Aquel aspecto de la apropiación está en relación con el concepto de propiedad; este con el de posesión" (tradução nossa).

${ }^{225}$ Idem, p.129. "En Alemania, sin embargo, se ha insistido en esta cuestión, no ya para destacar la diferencia entre hurto y apropiación indebida, sino la que existe entre un proceso físico y otro valorativo, o dicho de otro modo, entre un elemento descriptivo (Wehnahme) y otro normativo (Zueignung) - elementos que se desenvuelven, respectivamente, en los ámbitos externo e interno de la actividad del sujeto - diferencia a partir de la cual se capta la verdadera esencia del injusto de estos delitos" (tradução nossa).
} 
Como afirma Reale Júnior, "nos crimes em que o dano se destaca da ação e esta se desenrola por uma trilha conduzente à produção do resultado danoso (crime de resultado material), o legislador pune esta ação mesmo que não venha a efetivamente a atingir o resultado, criando-se, todavia, uma situação perigosa ao bem jurídico, que não foi lesado apenas por razões independentes da vontade do agente, pois a ação era potencialmente lesiva". 226

Crime tentado, por consequência, é a ação parcialmente adequada ao tipo penal no que concerne ao aspecto objetivo, pois na ação está presente a intenção da consumação do delito, colorindo a ação delituosa malsucedida e dando-lhe significado. Reale Júnior explica ainda que, como "é da figura consumada de um determinado crime que se extrairá sua figura tentada", 227 temos, para que haja tentativa no crime de apropriação indébita, de evidenciar a presença daquela característica de intenção do agente voltada à apropriação razoavelmente durável e definitiva da coisa alheia.

Contudo, ainda colhendo subsídios em Reale Júnior, ${ }^{228}$ é importante frisar que apenas essa intenção não basta, pois se é verdade que "a intenção que preside à atuação do agente é definidora do crime que se pretendia perpetrar", também não se pode negar que "deve haver um grau de certeza na inferência da intenção do agente, grau este que apenas se tem com a apreensão da execução de atos idôneos e inequívocos". Como visto, no que diz respeito à apropriação indébita, essa questão coloca-se de forma bastante peculiar em razão das dificuldades próprias da compreensão do sentido de um crime patrimonial sui generis e se resolve por meio da percepção do princípio reitor da figura penal, consistente na tutela da liberdade de atuação ou disposição do proprietário sobre sua coisa. No que diz respeito à questão da inequivocidade, devemos ter sempre em conta que esta, segundo o mesmo autor, "não deve restringir a tentativa tãosomente àqueles atos de execução que por si, sem auxílio de qualquer outra prova, revelem a intenção de cometer um determinado crime. A inferência da

\footnotetext{
${ }^{226}$ REALE JÚNIOR, Miguel, op. cit., p.281.

${ }^{227}$ Idem. Ibidem. p.281.

${ }^{228}$ REALE JÚNIOR, Miguel, op. cit., p. 286.
} 
intencionalidade realiza-se tendo em vista o conjunto de todas as circunstâncias, a partir evidentemente dos atos de execução, mas que nesse conjunto revelem, e de modo inequívoco, o objetivo do agente."229

Haverá, portanto, tentativa de apropriação indébita quando praticada uma conduta de apropriação da coisa alheia (consumo, alienação, desvio, retenção), não ocorrer o resultado típico, consistente na criação de um obstáculo ao exercício de um dos poderes imanentes ao domínio pelo legítimo proprietário da coisa, por circunstância alheia à vontade do agente.

Deve-se notar, por consequência, que o critério dominante de aferição da tentativa, ligado à unissubistência ou plurissubsistência da conduta (e invocado tanto por Antolisei quanto, de forma abrangente, pela nossa doutrina) não resolve, de todo ou mesmo essencialmente, o problema.

Se é verdade que na conduta plurissubsistente a intervenção de circunstância alheia à vontade do agente, anterior ao esgotamento da ação típica, pode levar ao reconhecimento da tentativa, não é menos verdade que haverá a possibilidade de, esgotada a ação, uni ou plurissubsistente não ocorrer o resultado lesivo à propriedade. $\mathrm{O}$ motivo da aceitação da tentativa, portanto e como visto, deve ser outro. Há que se reconhecer a tentativa, sem dúvida, mas porque, e sempre que, não houver a vulneração concreta, nos termos já expostos, do bem jurídico protegido, qual seja, a propriedade.

De tal forma que afirmações no sentido de que "o simples fato de oferecer à venda uma coisa basta para dar vida a uma apropriação consumada, ainda que o réu não encontre adquirente", ${ }^{230}$ tornam-se desprovidas de razão e somente podem representar aquela sobrevalorização do elemento subjetivo do delito de apropriação indébita que, com o melhor desenvolvimento da

\footnotetext{
${ }^{229}$ REALE JÚNIOR, Miguel, op. cit., p.286.

${ }^{230}$ PEDRAZZI, Cesare, op. cit., p. 845: “(...) il semplice fatto di offrire in vendita la cosa basta a dar vita a un'appropriazione consumata, anche se il reo non trovi acquirenti” (tradução nossa).
} 
compreensão do papel do bem jurídico protegido na economia do delito, não mais se pode justificar.

A razão, ao contrário, está com Antolisei (ainda que por motivos diversos dos alegados ${ }^{231}$ ), quando acaba por reconhecer a tentativa de apropriação indébita no caso "do indivíduo que seja surpreendido no decorrer da venda de um coisa havida em depósito". 232

É correto afirmar a tentativa também no exemplo em que, consumada uma venda à distância e após o esgotamento das ações do vendedor (inclusive com o recebimento do preço e a colocação da coisa à disposição do comprador), não consiga o comprador pegá-la na residência do vendedor, onde deveria se encontrar à sua disposição, justamente porque o seu legítimo proprietário retomou-a naquele local pouco antes. A tentativa existe também no caso em que o infiel possuidor de um automóvel anuncia o veículo em jornal de grande circulação, sendo surpreendido ao chegar ao local combinado para a entrega ao pretenso cobrador pela presença do legítimo proprietário do bem e da zelosa Força Pública. Não há, também aqui, qualquer dúvida sobre a tentativa, pois mais uma vez trata-se de hipótese na qual, praticada uma conduta de apropriação da coisa alheia (consumo, alienação, desvio, retenção), não ocorre o resultado típico, consistente na criação de um obstáculo ao exercício de um dos poderes imanentes ao domínio pelo legítimo proprietário da coisa, por circunstância alheia à vontade do agente.

Com o que se pode refazer, à guisa de conclusão, ainda que de forma resumida, o caminho interpretativo desenvolvido no presente trabalho.

Como visto, a doutrina e a jurisprudência brasileiras sobrevalorizam o elemento subjetivo do delito de apropriação indébita de tal forma que a própria ação típica é vista, muitas vezes, fundamentalmente como a

\footnotetext{
${ }^{231}$ Antolisei fundamenta a admissibilidade de tentativa, neste caso, na alegada plurissubistência da conduta (ANTOLISEI, Francesco, op. cit., p. 356).

${ }^{232}$ ANTOLISEI, Francesco, op. cit., p. 356: “(...) dell'individuo che venga colto mentre sta per vendere una cosa avuta in deposito" (tradução nossa).
} 
mera exteriorização daquele elemento subjetivo, sem valor em si, de forma a fixar-se o momento consumativo apenas com a demonstração da inversão do animus da posse.

Tal entendimento acaba por levar à atribuição, ainda que inconsciente, de um caráter formal ao delito de apropriação indébita. Assim, mesmo afirmando tratar-se de crime material, que admite tentativa, a maioria dos autores brasileiros acaba por inadmiti-la na realidade ou por admiti-la de forma restrita e casuística, sem qualquer critério sólido de sua aferição.

De tal forma, a atribuição de natureza formal ao delito de apropriação indébita (explícita no Direito italiano e implícita no Direito brasileiro) pode levar à desproporcional punição, por crime consumado, de condutas que em nada atingiram o bem jurídico protegido pelo tipo penal, qual seja, a propriedade.

Embora na maioria dos casos a conduta apropriativa de fato se faça acompanhar imediatamente do resultado lesivo à propriedade, há de se reforçar a constatação, decorrente da análise estrutural do crime de apropriação indébita, de que o seu resultado pode, por separado da conduta, não ocorrer em determinados casos, o que revela o caráter material do crime de apropriação indébita e evidencia a natural possibilidade de tentativa do delito.

A própria revelação do bem jurídico em questão também demonstra a natureza material do delito: deve-se entender o crime de apropriação indébita como crime contra a propriedade que, portanto, só se consuma no momento em que se impõe ao legítimo proprietário, na realidade concreta, um obstáculo ao exercício de um dos poderes imanentes ao domínio.

Com o que, a questão da tentativa resolve-se de forma natural: sempre que realizada pelo sujeito ativo uma conduta de apropriação da coisa alheia (tal como o anúncio ou a própria venda do bem à distância), sem que se 
imponha, na realidade concreta, por qualquer circunstância alheia à vontade do agente, um obstáculo ao exercício de um dos poderes imanentes ao domínio pelo legítimo proprietário da coisa, estar-se-á, no Direito Penal brasileiro, diante da tentativa do delito de apropriação indébita. 


\section{APROPRIAÇÕES INDÉBITAS MENORES}

SUMÁRIO: 4.1 Apropriação de coisa havida acidentalmente 4.2 Apropriação de tesouro 4.3 Apropriação de coisa achada. 4.4 Peculatoapropriação.

Compreendidas a estrutura típica e a economia do delito de apropriação indébita no Direito Penal brasileiro, é preciso demonstrar, ainda que sucintamente, de que forma se pode compreender, com fundamento na estrutura e economia do delito de apropriação indébitas estabelecidas no presente trabalho, determinados pontos relacionados às apropriações indébitas menores, previstas no artigo 169 do Código Penal ${ }^{233}$.

\footnotetext{
${ }^{233}$ Optou-se por não abordar o crime de apropriação indébita previdenciária fundamentalmente porque a estrutura típica do delito não guarda com a apropriação indébita a mesma identidade que as condutas previstas no artigo 169 do Código Penal, de forma que a transposição dos conceitos desenvolvidos no presente trabalho, para o crime previdenciário exigiria o estabelecimento de novos pressupostos quanto a estrutura do tipo penal, bem jurídico protegido e economia do delito que fugiriam, por completo, ao caráter acessório do presente capítulo.
} 


\subsection{Apropriação de coisa havida acidentalmente.}

O tipo penal constante do caput do artigo 169 do Código Penal, assim como o da apropriação indébita, prevista no artigo 168 do mesmo diploma legal, resguarda a propriedade das coisas móveis, mas contra a ação de “apropriar-se alguém de coisa alheia vinda ao seu poder por erro, caso fortuito ou força da natureza".

O erro é a noção não correspondente com a verdade, ou, nos dizeres de Noronha, "erro é um conhecimento não verdadeiro, contrário à verdade. É a noção falsa, é uma representação que, destoando da realidade, vicia a manifestação de vontade. Com ele estabelece-se uma relação jurídica entra duas ou mais pessoas, mas que não corresponde ao verdadeiro querer de, pelo menos, uma delas". ${ }^{234}$ É o caso, ainda citado por Noronha, do recebimento do móvel laboral já com o erro, no qual somente se descobre o equívoco após tê-lo em seu poder, ou seja, o agente passa a ter conhecimento de que aquele objeto não lhe era destinado. A partir deste momento deixa de existir a boa fé, sendo incumbido de restituir civil e penalmente o móvel ${ }^{235}$.

$\mathrm{Na}$ verdade, somente estaremos diante de erro quando o engano for alheio e o sujeito ativo receber de boa fé a coisa, não podendo haver, para caracterizar-se o presente tipo penal, um erro provocado ardilosamente, conformador do estelionato, conforme salienta Luiz Regis Prado. ${ }^{236}$

Referido autor esclarece "que não [se] pune o receber coisa vinda ao seu poder por erro, mas o apropriar-se. Donde, se quem recebeu a coisa,

\footnotetext{
${ }^{234}$ NORONHA, Edgard Magalhães, Direito Penal, vol. 2, São Paulo, Saraiva, 1955. p. 352.

${ }^{235}$ Idem. Ibidem.

${ }^{236}$ PRADO, Luiz Regis, Curso de Direito Penal Brasileiro, São Paulo, Revista dos Tribunais, 2001. p. 485.
} 
por erro, o descobre em momento sucessivo, é obrigado a restituí-la. Em tal caso, a má-fé substitui-se à boa-fé originária, permanecendo apenas um erro: o alheio". 237

É de se notar, ainda, que o erro pode recair: a) sobre a pessoa; b) sobre a coisa; c) sobre a obrigação. Hungria exemplifica de forma concisa os referidos casos: "João da Silva recebe do estafeta postal um registrado valor destinado a um homônimo" - erro quanto à pessoa; "Tício recebe de Caio, ao invés do colar de pérolas falsas que lhe comprara, um colar de pérolas autêntica" erro quanto a coisa; "Primus recebe de Secundus o pagamento de uma dívida já paga ou quantia maior que a devida" - erro quanto à obrigação. ${ }^{238}$

Por derradeiro, independente das distinções mencionadas, como apresentadas por Noronha deve-se "ter em conta [para a existência do crime], sem limitações ou restrições, o erro, qualquer que seja, desde que seja causa do estabelecimento da posse do agente sobra a coisa alheia". ${ }^{239}$

De outro lado, o caso fortuito e a força maior, são vistos pela doutrina como situações semelhantes, nas quais a distinção é meramente doutrinária, tendo em vista que ambas independem da vontade humana no negócio jurídico.

Noronha aduz que “(...) caso fortuito é o acaso; é o efeito produzido por causa estranha, não imputável àquelas pessoas. Força da natureza ou força maior é o evento físico, natural. É o efeito de toda física ininteligente. Assim, o vento, o incêndio, o terremoto, as correntes de água (rios e mares), a inundação, etc (...) cremos que o caso fortuito é gênero e a força da natureza é espécie. Tanto um como outra não estão subordinados à consciência ou vontade do sujeito ativo e do passivo, não lhes sendo imputáveis, apresentando a segunda

\footnotetext{
${ }^{237}$ NORONHA, Edgard Magalhães, op. cit., p. 352.

${ }^{238}$ Hungria, Nelson, Comentários ao Código Penal, Rio de Janeiro, Forense, 1955. p.146.

${ }^{239}$ NORONHA, Edgard Magalhães, op. cit., p. 353.
} 
apenas a particularidade de ser o efeito de uma causa natural ou física, enquanto o primeiro comporta efeitos de outras causas". 240

Hungria, por sua vez, esclarece que "o dispositivo legal menciona o caso fortuito e a fôrça da natureza, fazendo, a exemplo, aliás, do Código suíço, uma distinção que se pode dizer desnecessária, pois o caso fortuito abrange todo e qualquer acontecimento estranho, na espécie, à vontade do agente e do dominus. Tanto é caso fortuito se a coisa alheia vem ao meu poder em conseqüência da queda de um avião em meu terreno, quanto se foi trazida pela correnteza de uma enchente. Se bois alheios, por mero instinto de vagueação ou acossados pelo fogo de uma queimada, entram nas minhas terras, ou se peças de roupa no coradouro do meu vizinho são impelidas por um tufão até o meu quintal, tudo é caso fortuito. Também aqui, a detenção da res aliena não é, em si mesma, criminosa: o que constitui o crime previsto no art. 169 é a ulterior apropriação por parte do detentor, ciente e consciente de faltar à obrigação ex lege de restituir aquilo que é de outrem". 241

Quanto a ação típica, como não poderia deixar de ser, é pacífico na doutrina que o núcleo do tipo (apropriar-se) é idêntico ao do delito de apropriação indébita, razão pela qual a diferenciação entre tais crimes se dá pelo modo com o qual o sujeito ativo assume a posse da coisa alheia.

Nesse sentido, ensina Prado que "a ação incriminada é idêntica à do art. 168. Todavia, o modo como a coisa alheia passa a ser possuída pelo sujeito ativo é distinto. Com efeito, o poder de fato sobre o bem pode ser transferido sem que interfira o elemento vontade (entendida, aqui, aquela que não seja viciada). Pois bem, na transmissão da posse por erro, caso fortuito ou força da natureza, inexiste esse elemento". 242

\footnotetext{
${ }^{240}$ Idem. p. 354.

${ }^{241}$ HungRIA, Nelson, op. cit., pp. 145-146.

${ }^{242}$ Prado, Luiz Regis, op. cit., p. 484. No mesmo sentido: Delmanto, Celso, et. al., Código Penal Comentado, Rio de Janeiro, Renovar, 2002. p. 514.
} 
Referida observação, segundo Greco, leva a conclusão de que "ao contrário do que ocorre com a apropriação indébita, o agente não tinha, licitamente, a posse ou detenção da coisa. Aqui, ela vem ao seu poder por erro, caso fortuito ou força da natureza”.243

Como bem observado por Noronha, de outro lado, "a posse da coisa pelo agente, mediante erro, caso fortuito ou força da natureza, é um pressuposto do crime, e até aí não há ação qualquer de agente. A coisa lhe veio ao poder, por fatores independentes da vontade, por circunstâncias que the eram imprevistas e que não foram geradas por qualquer concepção criminosa de sua parte". 244

Dessa forma, como inexiste diferença estrutural entre os crimes de apropriação indébita e apropriação de coisa havida acidentalmente, não é de se admirar que a doutrina brasileira reproduza sua visão sobre a questão da consumação e tentativa daquele delito no estudo deste.

Por consequência, a consumação no delito de apropriação indébita decorrente de erro, caso fortuito ou força maior decorreria, para nossa doutrina, também da inversão do título de posse, ou seja, ocorreria com a apropriação da coisa, naquele sentido formal já observado no presente trabalho.

Nesse sentido, de acordo com Noronha "o delito do art. 169 consuma-se no mesmo momento que o art. 168: com a apropriação da coisa; com a inversão do título da posse em domínio, isto é, quando, já tendo o móvel em seu poder, comporta-se o agente tal qual dono fosse" 245

O mesmo entendimento é mantido por Greco ao advogar que "consuma-se o delito em estudo quando o agente, depois de tomar conhecimento de que a coisa alheia móvel chegou ao seu poder por erro, caso fortuito ou força

\footnotetext{
${ }^{243}$ GRECO, Rogério, Curso de Direito Penal - Parte Especial, vol. 3, Niterói, Impetus, 2006. p. 244.

244 NorONHA, Edgard Magalhães, op. cit., p. 354.

${ }^{245}$ Idem, p. 355.
} 
da natureza, resolve, mesmo assim, com ela permanecer, agindo como se fosse dono" 246

No tocante à tentativa, a maioria da doutrina, mais uma vez, de forma casuística, entende ser possível, porém de difícil ocorrência ou caracterização na prática.

Para Greco, "será possível o raciocínio correspondente a tentativa quando o agente, por exemplo, agindo como se fosse dono, tiver dado início aos atos tendentes a se desfazer da coisa, momento em que é surpreendido. A tentativa, portanto, deverá ser avaliada caso a caso, considerando-se a maneira pela qual a infração penal é praticada”. ${ }^{247}$ Ao que parece, reafirma-se, também aqui, o critério da admissão da tentativa nas condutas plurissubsistentes, tão freqüente no tratamento da tentativa de apropriação indébita.

Em sentido contrário, para Luiz Regis Prado, por entender que a consumação ocorre no momento em que o sujeito ativo inverte o título da posse, com animus rem sibi habendi, a tentativa seria inadmissível".248

Por sua vez, Damásio de Jesus, estabelece duas possibilidades, em relação a apropriação indébita comum, mas que entende ser aplicável neste

\footnotetext{
${ }^{246}$ GRECO, Rogério, op. cit., p. 246.

${ }^{247}$ Idem. Ibidem.

${ }^{248}$ PRADO, Luiz Regis, op. cit., p. 490. Vale lembrar, nesse ponto, as considerações de Prado sobre a tentativa de apropriação indébita. Para o autor "a possibilidade da ocorrência de tentativa na apropriação é tema que provoca dissidências doutrinárias, em face das peculiaridades do crime, com destaque para seu elemento subjetivo. De fato, é extremamente difícil fixar o momento em que se apresenta elemento subjetivo transformador da posse, de alheia para própria (animus rem sibi habendi)"'. Referido autor expõe suas razões ao criticar o posicionamento de Hungria, e afirma: "Aqueles que admitem a tentativa expedem argumentos puramente empírico, enquanto aqueles que inadimitem o conatus o fazem sobre sólida articulação técnica, Perfilha-se a segunda posição, pois a apropriação é crime instantâneo que pressupõe a posse ou a detenção pelo sujeito ativo, consumandose com a exteriorização de sua vontade de não restituir" Ademais, Luiz Regis Prado exemplifica seu entendimento com a situação do proprietário que flagra o possuidor no momento em que está vendendo a coisa, sendo impedido de tradicioná-la ao comprador. Citado autor arremata: "é até mesmo ilógico pretender-se o reconhecimento do conatus sob o argumento de que nenhum fato anterior evidencia efetiva apropriação, sendo insofismável a circunstância de que se o possuidor está alienando, agindo como se dono fosse, restando consumado o crime ante a inequívoca prova de inversão de título da posse (consciência de que não restituiria a coisa)". Por estas convicções, não admite a tentativa.
} 
delito assemelhado. A primeira admite tentativa "na hipótese de apropriação indébita propriamente dita. Ex.: o sujeito é surpreendido no ato de vender a coisa de que tinha posse ou a detenção". A outra possibilidade é a impossibilidade de tentativa quando ocorrer a "negativa de restituição". Sendo assim, segundo este autor, "ou o sujeito se nega a devolver o objeto material, e o delito está consumado, ou isso não ocorre, não havendo conduta típica". ${ }^{249}$

Tais considerações, contudo, merecem o mesmo reparo efetuado em relação à consumação e tentativa do crime de apropriação indébita previsto no art. 168 do Código Penal.

Como já se pôde observar em relação à apropriação indébita, a doutrina e a jurisprudência brasileiras sobrevalorizam o elemento subjetivo daquele delito de tal forma que a própria ação típica é vista, muitas vezes, fundamentalmente como a mera exteriorização daquele elemento subjetivo, sem valor em si, de forma a fixar-se o momento consumativo apenas com a demonstração da inversão do animus da posse.

Tal entendimento acaba por levar à atribuição, ainda que inconsciente, de um caráter formal ao delito de apropriação indébita e, por conseqüência, também ao crime de apropriação de coisa havida acidentalmente. Assim, mesmo afirmando tratar-se de crime material, que admite tentativa, a maioria dos autores brasileiros acaba por inadmiti-la na realidade ou por admiti-la de forma restrita e casuística, sem qualquer critério sólido de sua aferição, em ambos os casos.

De tal maneira, como já desenvolvido no presente trabalho, a atribuição de natureza formal ao delito de apropriação indébita (explícita no Direito italiano e implícita no Direito brasileiro) pode levar à desproporcional punição, por crime consumado, de condutas que em nada atingiram o bem jurídico protegido pelo tipo penal, qual seja, a propriedade.

${ }^{249}$ Jesus, Damásio Evangelista de, Direito Penal, vol. 2, São Paulo, Saraiva, 1997. p. 415. 
Embora na maioria dos casos a conduta apropriativa de fato se faça acompanhar imediatamente do resultado lesivo à propriedade, e ainda mais freqüentemente no caso do art. 169 do Código Penal, em razão de seu caráter essencialmente omissivo, há de se reforçar a constatação, decorrente da análise estrutural do crime de apropriação indébita, e também aplicável ao crime em comento, de que o resultado tipico pode, por separado da conduta, não ocorrer em determinados casos, o que também revela o caráter material do crime de apropriação de coisa havida acidentalmente e evidencia a natural possibilidade de tentativa do delito.

A própria revelação do bem jurídico em questão também demonstra a natureza material do delito: também se deve entender o crime de apropriação de coisa havida acidentalmente, por absoluta semelhança com a apropriação indébita, como crime contra a propriedade que, portanto, só se consuma no momento em que se impõe ao legítimo proprietário, na realidade concreta, um obstáculo ao exercício de um dos poderes imanentes ao domínio.

Com o que, a questão da tentativa resolve-se de forma natural: sempre que realizada pelo sujeito ativo uma conduta de apropriação da coisa alheia havida acidentalmente (tal como o anúncio ou a própria venda do bem à distância), sem que se consiga impor, na realidade concreta, por qualquer circunstância alheia à vontade do agente, um obstáculo ao exercício de um dos poderes imanentes ao domínio pelo legítimo proprietário da coisa, estar-se-á, no Direito Penal brasileiro, diante da tentativa do delito. 


\subsection{Apropriação de tesouro}

O artigo 169, Parágrafo único, inciso I do Código Penal, pune, por sua vez, o agente que acha, casualmente, tesouro, em propriedade alheia e se apropria, no todo ou em parte, da quota a que tem direito o proprietário do prédio $^{250}$

Devemos entender o tesouro como coisas móveis, antigas, preciosas, ocultas e de cujo dono não haja memória, ou seja, desconhecido o seu proprietário (definição esta prevista no Código Civil de 1916).

Neste sentido, ressalta Hungria que "característico do tesouro é o fato de ser desconhecido o seu proprietário; se alguém demonstra ser dono do depósito achado, não há de se falar propriamente em tesouro". ${ }^{251}$ Também Noronha confirma o requisito supra mencionado ao relatar que "para haver tesouro é necessário, pois, ser o dono inexistente". 252

Vale ressaltar que, como destaca Bitencourt, o tesouro deve ser encontrado acidentalmente, sem, no entanto, estar sendo procurado. Tendo em vista que, uma vez encontrado pelo dono do prédio, por pesquisadores a seu mando ou, até mesmo, por terceiros não autorizados, o tesouro pertencerá

\footnotetext{
${ }^{250}$ Para melhor compreensão, empresta-se do Código Civil, os artigos 1.264, 1.265 e 1.266, que cuidam do achado do tesouro: Art. 1.264. O depósito antigo de coisas preciosas, oculto e de cujo dono não haja memória, será dividido por igual entre o proprietário do prédio e o que achar o tesouro casualmente. Art. 1.265. O tesouro pertencerá por inteiro ao proprietário do prédio, se for achado por ele, ou em pesquisa que ordenou, ou por terceiro não autorizado. Art. 1.266. Achando-se em terreno aforado, o tesouro será dividido por igual entre o descobridor e o enfiteuta, ou será deste por inteiro quando ele mesmo seja o descobridor.

${ }^{251}$ HUNGRIA, Nelson, op. cit., p. 148.

${ }^{252}$ NORONHA, Edgard Magalhães, op. cit., p. 360.
} 
integralmente ao proprietário do prédio, haverá, se for esse o caso, o crime de furto e não o de apropriação de tesouro. ${ }^{253}$

Nesse sentido, para Hungria: "se o tesouro é encontrado, não por obra do acaso (fortuito casu), mas opera ad hoc data, posto que sem prévia determinação ou sem assentimento do dono do prédio, sua propriedade é exclusivamente deste (art. 608); de modo que sua apropriação pelo achador é furto e não o crime de apropriação de tesouro". ${ }^{254}$

Também acompanha este raciocínio Bitencourt ao afirmar que "o ato de achar deve ser um acontecimento fortuito, acidental, involuntário, sob pena de caracterizar crime de furto". E continua, "é indispensável, contudo, que esse conjunto de preciosidades seja encontrado acidentalmente, caso contrário não haverá a obrigação de dividi-lo com o proprietário (art. 1.265 do CC). ",255

De qualquer forma, conforme esclarece Hungria "pode o tesouro achar-se escondido no solo ou em qualquer outro local, mesmo dentro de um móvel (ex: moedas depositadas no escaninho secreto de uma velha arca). Não é, porém, tesouro o depósito natural de pedras preciosas (pois tal depósito, diversamente do tesouro enterrado, é acessorium do solo e, como tal, ainda que descoberto casualmente por terceiro, é propriedade inteira do dono do solo, desde que dominus soli, dominus est coeli et inferiorum, salvo as exceções legais)" ${ }^{256}$

Tratando do enfiteuta, o Código Civil determina que o tesouro seja dividido por igual entre o descobridor e o enfiteuta, ou será deste por inteiro quando ele mesmo seja o descobridor, conforme esclarece Noronha, "neste caso, o titular do aforamento exclui o proprietário. Dando-se a invenção, o tesouro será dividido em duas partes iguais entre inventor e enfiteuta, e consequentemente, se

\footnotetext{
${ }^{253}$ Bitencourt, Cezar Roberto, Tratado de Direito Penal, São Paulo, Saraiva, 2004. p. 220.

${ }^{254}$ HUNGRIA, Nelson, op. cit., pp 147-148.

${ }^{255}$ BitenCOURT, Cezar Roberto, op. cit., p. 220.

${ }^{256}$ HunGRIA, Nelson, op. cit., p. 148.
} 
o primeiro se apodera do tesouro, apropria-se da parte que compete ao segundo". 257

Demonstra Hungria, então, com razão que "a apprehensio ou contrectatio do tesouro pelo achador casual constitui ato lícito (e por isso não se poderia identificar o crime de furto): ilícita é somente a posterior apropriação, no todo ou em parte, da cota pertencente ao proprietário do prédio”. ${ }^{258}$

Seguindo a lógica formal já demonstrada, entendem os nossos autores que consuma-se o delito em estudo quando o agente, após achar o tesouro, comporta-se como verdadeiro dono, no todo ou em parte, da quota a que tem direito o proprietário do prédio, assim o agente apropria-se com animus rem sibi habendi. Assim, para Prado "a consumação acontece com a inversão do título da posse no que concerne à metade do tesouro. " 259

Nesse sentido, Greco limita-se a dispor que "o crime se configura quando, depois de encontrado o tesouro, o agente se apropria da quota que caberia ao proprietário do imóvel ou enfiteuta." 260

Em relação à tentativa, reproduz-se de forma muito evidente aquela particular contradição entre a afirmação da natureza material do delito e o não reconhecimento de um critério para aferição da tentativa compatível com tal entendimento.

Neste sentido, Noronha assevera que "como já se falou, o crime é de dano, que é inerente à apropriação, a qual, por si, acarreta diminuição patrimonial ao sujeito passivo. Doutrinariamente admite tentativa, sendo, entretanto, muito difícil sua caracterização na prática (n.556) „261.

\footnotetext{
${ }^{257}$ NorONHA, Edgard Magalhães, op. cit., p. 357.

${ }^{258}$ HUNGRIA, Nelson, op. cit., p. 148.

${ }^{259}$ PRADO, Luiz Regis, op. cit., p. 486.

${ }^{260}$ GRECO, Rogério, op. cit., p. 249.

${ }^{261}$ NORONHA, Edgard Magalhães, op. cit., p. 335.
} 
Com entendimento semelhante, Greco afirma que "tendo em vista a possibilidade de ser fracionado o iter criminis, entendemos admissível a tentativa na infração penal em estudo". ${ }^{262}$ Mais uma vez, recorre-se ao insuficiente critério da plurissubsistência para explicar a possibilidade de tentativa, sem levar em conta os casos nos quais, esgotada a conduta, o resultado (lesivo à propriedade) não ocorre por circunstância alheia à vontade do agente.

Com entendimento diverso, Prado insiste, também aqui, na inadmissibilidade de tentativa ${ }^{263}$.

Diante do que, reafirma-se a necessidade de manifestação do princípio estabelecido no presente trabalho, também para o crime de apropriação de tesouro, segundo o qual, por se tratarem as apropriações (em geral) de crimes materiais, cuja consumação se dá no momento em que se impõe ao legítimo proprietário, na realidade concreta, um obstáculo ao exercício de um dos poderes imanentes ao domínio, há que se reconhecer a tentativa sempre que realizada uma conduta típica o resultado não ocorrer por circunstância alheia à vontade do agente. Deve-se advertir, no entanto, que no caso particular da apropriação de tesouro, a própria retirada dos objetos de valor da propriedade alheia, sem aviso a quem de direito, já pode representar a imposição daquele obstáculo ao exercício dos poderes inerentes ao domínio, suficientes ao reconhecimento da consumação do delito.

\subsection{Apropriação de coisa achada.}

Previsto no inciso II do parágrafo único do art. 169, do Código Penal, a conduta apropriação de coisa achada se refere à conduta de "quem acha coisa alheia perdida e dela se apropria, total ou parcialmente, deixando de restituí-

\footnotetext{
${ }^{262}$ GRECO, Rogério, op. cit., p. 250.

${ }^{263}$ PRADO, Luiz Regis, op. cit., p. 487.
} 
la ao dono ou legítimo possuidor ou de entregá-la à autoridade competente, dentro no prazo de quinze dias".

O dispositivo penal tutela a inviolabilidade do patrimônio (naquela particular consideração referente à tutela da propriedade, própria das apropriações no direito penal).

Nesse sentido, destaca Noronha, com razão, que "visando à proteção do patrimônio, tutela o dispositivo especificamente o direito de propriedade, que não desaparece com a perda da coisa. De feito, perdida esta, o proprietário ainda conserva o direito sobre ela, podendo reivindicá-la do poder de quem a detenha". ${ }^{264}$

No mesmo sentido a afirmação de Greco segundo a qual “aquele que perde a coisa não perde o seu domínio. Continua a ser seu dono, mesmo não tendo a posse direta". Contudo o autor faz distinção entre coisa perdida e coisas esquecidas ou deixadas voluntariamente. Em seu entendimento, “coisa perdida é aquela que seu dono ou possuidor não sabe onde efetivamente se encontra, e coisa esquecida é aquela que, temporariamente, foi esquecida em algum lugar conhecido pelo seu dono". ${ }^{265}$ Enfatiza-se a diferenciação para a melhor caracterização do delito pois, quando o agente apropria-se de coisas esquecidas ou deixadas voluntariamente pela própria vítima estar-se-á diante do crime de furto.

Entendimento semelhante é o de Prado, para o qual “compreende-se coisa perdida não aquela abandonada ou sem dono (res nullius), mas a que deixou a custódia de seu proprietário ou possuidor, que ignoram onde se encontra", e conclui que, "portanto, deve ter saído casualmente do poder de fato do dominus (ou possuidor legítimo), não podendo ser por este recuperada, mostrando-se insuficiente que tenha somente esquecida".

\footnotetext{
${ }^{264}$ NORONHA, Edgard Magalhães, op. cit., pp. 361-362.

${ }^{265}$ GRECO, Rogério, op. cit., p. 251.
} 
O Código Civil, em seu art. 1.233, reconhece o dever do agente em restituir, ao seu legítimo proprietário ou à autoridade competente dono ou legítimo possuído, a coisa alheia encontrada, nos seguintes termos: “Art. 1.233. Quem quer que ache coisa alheia perdida há de restituí-la ao dono ou legítimo possuidor. Parágrafo único. Não o conhecendo, o descobridor fará por encontrálo, e, se não o encontrar, entregará a coisa achada à autoridade competente."

Vale ressaltar que o Código Penal determina a restituição da coisa alheia dentro no prazo de quinze dias. O decurso temporal criado pelo legislador tem a finalidade de proporcionar ao agente um prazo suficiente para restituir a coisa alheia.

Greco afirma que "se o agente for surpreendido com a coisa perdida ainda no prazo legal, não se poderá concluir pelo delito de apropriação de coisa achada, visto que, para sua configuração, deverá ter decorrido o prazo estipulado pela lei penal". ${ }^{266}$

Esclarece Bitencourt que "é equivocada a afirmativa de que o legislador previu prazo para o crime consumar-se, uma vez que o prazo de quinze dias constitui uma elementar típica. Sua previsão legal tem sentido apenas político-criminal, objetivando proporcionar ao indivíduo tempo suficiente para efetuar a devolução ou entrega da coisa alheia”.

Acrescenta, ainda, que "a obrigação de devolver a res perdida, na verdade, surge desde o momento em que o agente a encontra e tem ciência desse estado da coisa encontrada. A autoridade competente que tiver conhecimento desse fato deve efetuar busca e apreensão, embora o crime não haja: a infração civil opera-se a partir do momento que o 'achador' retém a coisa achada em seu poder; o crime, contudo, somente se configurará a partir do momento em que se completarem quinze dias sem a entrega da coisa achada à

${ }^{266}$ Idem, p. 252. 
autoridade competente, pois somente a partir daí a apropriação torna penalmente relevante". ${ }^{267}$

É de se notar, aliás, por oportuno, que "o simples deixar de entregar a coisa achada à autoridade competente no prazo de quinze dias ou de devolvê-la ao proprietário que se tornou conhecido é insuficiente para tipificar o crime de apropriação de coisa achada; é indispensável que a omissão na entrega ou devolução seja orientada pelo animus rem sibi habendi". ${ }^{268}$

Como exemplo, cita Greco "a hipótese daquele que, depois de encontrar a coisa perdida, decide entregá-la à autoridade policial. No entanto, em virtude de seus compromissos particulares, vai adiando a sua ida à Delegacia de polícia até que, sem perceber, permite que haja o decurso do tempo legal, vale dizer, os 15 dias exigidos pelo inciso II do parágrafo único do art.169 do Código Penal". E prossegue o autor: "nesse caso, não se pode imputar qualquer infração penal ao sujeito, haja vista que, embora o decurso do tempo seja fundamental ao reconhecimento do delito, não se pode abrir mão do elemento subjetivo, vale dizer, do dolo com que atuava o agente no sentido de apropriar-se da coisa achada". 269

No mesmo sentido, para Hungria "o fato de não restituir a coisa ao proprietário (ou possuidor legítimo), se o agente o conhece ou vem a conhecêlo ex post, ou de não entregá-la à autoridade competente no prazo legal, não é por si só, o crime: cumpre que seja informado de inequívoco animus rem sibi habendi. Se a conduta omissiva do achador resulta de força maior ou de mera negligência, não há crime (só punível a título de dolo). A própria expiração do prazo de 15 dias, sem entrega da coisa à autoridade, não faz surgir, fatalmente, o crime: não passa de uma presunção juris tantum, isto é, que pode ser elidida por prova em contrário". 270

\footnotetext{
${ }^{267}$ BitenCOURT, Cezar Roberto, op. cit., p. 222.

${ }^{268}$ Idem, p. 223.

${ }^{269}$ GRECO, Rogério, op. cit., p. 254.

${ }^{270}$ Hungria, Nelson, op. cit., pp.152-153.
} 
Nesse sentido, como não poderia deixar de ser, para a ocorrência do delito exige-se do agente a vontade livre e consciente no sentido de se apropriar da coisa alheia móvel, ou seja, o animus rem sibi habendi, próprio das apropriações no direito penal.

De outro lado, para Bitencourt "faz-se necessário o especial fim de obter vantagem em proveito próprio ou alheio. $\mathrm{O}$ elemento subjetivo na apropriação de tesouro é igualmente o dolo, representado pela vontade de apropriar-se dele, e o especial fím da obtenção da vantagem, constituída pela metade a que faz jus o dono do prédio onde o tesouro foi encontrado". ${ }^{271}$ Como bem explicado anteriormente, tal concepção se prende a uma visão patrimonialista da tutela penal em questão e deve ser afastada em razão da compreensão de que os crimes em tela, embora possam representar um ataque ao patrimônio, nem sempre o representam, subsistindo o crime no caso de violação da propriedade de insignificante valor econômico, desde que se esteja a tutelar, com a propriedade, outros valores caros à sociedade, como os sentimentos familiares, o respeito aos mortos ou a manifestação religiosa, por exemplo.

Em termo de consumação, Greco defende que "a conjugação do elemento subjetivo (dolo) com o decurso do tempo (prazo de 15 dias) é que permite o reconhecimento do delito de apropriação de coisa achada" ${ }^{272}$ Portanto, para o autor, “consumação da infração penal somente ocorrerá após o decurso do mencionado prazo legal. Mesmo que o agente já tenha decidido não devolvê-la, se ainda estiver no prazo legal, seu comportamento será considerado um indiferente penal, pois que o tipo penal, para sua configuração, encontra-se condicionado ao decurso do prazo de 15 dias". 273

Ou seja, a consumação, em que pese a mesma dificuldade de caracterização, ocorreria, não mais, tão somente, com a inversão do animus da

\footnotetext{
${ }^{271}$ BITENCOURT, Cezar Roberto, op. cit., p. 223.

${ }^{272}$ GRECO, Rogério, op. cit., p. 254.

${ }^{273}$ Idem, p. 253.
} 
posse, mas com a conjugação desta com o esgotamento do prazo para entrega da coisa à autoridade policial.

Pelas mesmas razões acima apresentadas, Greco não admite a tentativa "uma vez que, mesmo tendo resolvido psiquicamente não devolver a coisa achada, mas se ainda estiver no prazo legal, se for descoberto o agente, o fato será atípico; ao contrário, se, agindo com animus de se apropriar da coisa achada, deixar ultrapassar o prazo de 15 dias, o delito já estará consumado."274

Divergente é o entendimento de Prado para quem, "a consumação ocorre com a apropriação, independentemente do prazo de 15 dias fixado no tipo penal, ou seja, desnecessário aguardar o decurso do prazo se, antes, o sujeito ativo alienar a coisa, isto é, praticar atos próprios do dono. Por essas razões, a exemplo do que disse sobre a apropriação indébita comum, é inadmissível a figura da tentativa". ${ }^{275}$

Não há, no entanto, razão em tais raciocínios, ao menos no que diz respeito aos postulados estabelecidos no presente trabalho.

Com efeito, deve-se lembrar, mais uma vez, a necessidade de manifestação do princípio estabelecido no presente trabalho, também para o crime de apropriação de coisa achada, segundo o qual, por se tratarem as apropriações (em geral) de crimes materiais, cuja consumação se dá no momento em que se impõe ao legítimo proprietário, na realidade concreta, um obstáculo ao exercício de um dos poderes imanentes ao domínio, há que se reconhecer a tentativa sempre que realizada uma conduta típica o resultado não ocorrer por circunstância alheia à vontade do agente.

Daí porque se pode reputar equivocada a primeira opinião, segundo a qual sempre se há de exigir, para a consumação do delito de apropriação de coisa achada, o decurso do prazo de quinze dias estabelecido pela lei para a devolução do objeto material do crime.

\footnotetext{
274 Idem, p. 253.

${ }^{275}$ PRADO, Luiz Regis, op. cit., p. 488.
} 
Uma vez estabelecida a presença do animus rem sibi habendi e realizado ato de apropriação que efetivamente tenha lesionado a propriedade, ou o poder de disposição do proprietário sobre a coisa, não há qualquer motivo para, diante da inequivocidade da conduta e do completo aperfeiçoamento do resultado típico, se negar a consumação do delito.

De outro lado, como exaustivamente discutido no presente trabalho, não há que se negar a possibilidade de tentativa de apropriação de coisa achada. Empreendendo o autor, dentro do prazo originariamente destinado à devolução da coisa, atos destinados à sua venda e surpreendido pela autoridade ou mesmo pelo proprietário do bem antes de efetivar a entrega do bem ao comprador, há que se reconhecer, diante da inexistência de dano à propriedade, a tentativa do delito cujo resultado não chegou a se realizar.

\subsection{Peculato-apropriação}

A origem do peculato remonta ao Direito Romano. Conforme nos relata Hungria "a subtração de coisas pertencentes ao Estado chamava-se peculatus ou depeculatus, sendo este nomen juris oriundo do tempo anterior a introdução da moeda, quando os bois e carneiros (pecus), destinados aos sacrifícios, constituíam a riqueza pública por excelência". ${ }^{276}$

$\mathrm{Na}$ época, segundo referido autor, não importava a qualidade do sujeito ativo (funcionário público), sendo considerado como caracterizador do delito contra a administração a natureza pública (religiosa ou política) do objeto material do crime. ${ }^{277}$

\footnotetext{
${ }^{276}$ HUNGRIA, Nelson. op. cit., 1955. p.330.

${ }^{277}$ HUNGRIA, Nelson. op. cit., 1955. p.330.
} 
Mais adiante, destacam-se as penas rigorosíssimas, em conformidade com a índole dos Estados, absolutistas ou totalitários. Nesse sentido, destaca Hungria que "o Estatuto de Florença, por exemplo, (...) ia ao extremo de prescrever [que] quem fugisse com o dinheiro publico devia ser amarrado à cauda de um burro e arrastado pela cidade" ${ }^{278}$, enquanto, muito mais modernamente, o Código soviético cominava, em caso de peculato, 'quando praticado em razão de especiais poderes plenos ou se refira a valores estatais particularmente importantes', as penas de fuzilamento e confisco de bens (art. $115,2 .^{\mathrm{a}}$ al.). ${ }^{279}$

No Brasil, ainda segundo Hungria, “já o Código de 1830 cogitava do peculato entre 'os crimes conta o Tesouro público, e propriedade publica'. O primeiro Código republicano passou a classificá-lo entre 'os crimes contra a administração pública', mas reproduzindo os moldes antigos. Naturalmente alarmado com a freqüência e crescente vulto dos desfalques nos dinheiros públicos, o legislador pátrio, em sucessivos diplomas legais, cuidou, no correr dos tempos, de tornar mais compreensivo a fórmula in abstracto do crime $\mathrm{e}$ de majorar as penas anteriormente cominadas. O expedido por derradeiro, antes do atual Código, fôra o dec. N. ${ }^{\circ} 4.780$, de 27-12-1923, cujo arts. $1 .^{\circ}$ a $4 .^{\circ}$ vieram a constituir os arts. 221 a 223 da revogada Consolidação das Leis Penais”." 280

Atualmente, nos termos do art. 312 do Código Penal de 1940, considera-se peculato o ato de "apropriar-se o funcionário público de dinheiro, valor ou qualquer outro bem móvel, público ou particular, de que tem a posse em razão do cargo, ou desviá-lo, em proveito próprio ou alheio”.

Trata-se de crime próprio, pois, conforme destaca Bitencourt, "é necessário que pelo menos um dos autores reúna a condição especial de funcionário público, podendo os demais não possuir tal qualidade”, em razão da

\footnotetext{
${ }^{278}$ HUNGRIA, Nelson. op. cit., 1955. p.330.

${ }^{279}$ HUNGRIA, Nelson. op. cit., 1955. p.331.

${ }^{280}$ HUNGRIA, Nelson. op. cit., 1955. p.332.
} 
comunicação das elementares do tipo penal, prevista expressamente, no artigo 30 do Código Penal. ${ }^{281}$

Segundo o autor, contudo, para que haja co-autoria ou participação "é indispensável, que o particular (extraneus) tenha consciência da qualidade especial do funcionário público, sob pena de não responder pelo crime de peculato. Desconhecendo essa condição, o dolo do particular não abrange todos os elementos constitutivos do tipo, configurando-se o conhecido erro de tipo, que afasta a tipicidade da conduta".

Em outro ponto relacionado à condição do agente, Prado revela que "como o tipo de injusto exige como um dos seus elementos que o agente pratique a conduta delitiva em razão do cargo que ocupa, esse exercício deve ser precedido de regular nomeação oficial. De modo que, no caso de mera ocupação de fato do cargo público, como no caso da usurpação de função, além do delito do artigo 328, o agente poderá responder pelos crimes de furto ou estelionato, mas não pelo de peculato, salvo se a ocupação resulta de nomeação irregular reconhecida posteriormente, quando então será possível o reconhecimento da prática do crime funcional em análise". ${ }^{282}$

Destaca-se, por evidente, a aparência do peculato com o já estudado delito de apropriação indébita. Nos dizeres de Hungria "o peculato, na sua configuração central, não é mais que a apropriação indébita (embora com certa diferença de disciplina) praticada por funcionário público ratione officii". ${ }^{283}$ Assim, a figura do funcionário público é, sem sombra de dúvida, um diferenciador entre os delitos, uma vez que, ainda segundo o autor, "se na apropriação indébita a coisa é confiada ou entregue voluntariamente, no peculato

\footnotetext{
${ }^{281}$ BITENCOURT, Cezar Roberto. Tratado de direito penal. São Paulo, Saraiva, 2004. p.7.

${ }^{282}$ PRADO, Luiz Regis. Curso de direito penal brasileiro. São Paulo : Revista dos Tribunais, 2001. p.348/349.

${ }^{283}$ HUNGRIA, Nelson. op. cit., 1955. p.332.
} 
a posse ou detenção resulta da confiança imposta pela lei como indispensável ao cargo público exercido pelo agente". ${ }^{284}$

Figura a posse licita, com clareza, assim como na apropriação indébita, como pressuposto indispensável à configuração do delito. Prado alerta, no entanto, que "ao contrário da apropriação indébita, em que o legislador faz expressa menção à figura da detenção, no peculato o tipo objetivo refere-se tão somente à posse. Contudo, esta deve ser enfocada em sentido amplo, alcançando não só a detenção, como também a posse indireta, compreendendo esta última o que se denomina disponibilidade jurídica, em que apesar de não dispor da detenção material da coisa o agente a exerce mediante ordens, requisições ou mandados, como ocorre com o chefe de determinado órgão público onde se guardam valores" ${ }^{, 285}$.

Note-se, aliás, que assim como na apropriação indébita a posse não pode estar viciada, pois conforme leciona Fragoso "se ela decorrer de erro, o crime será o do art. 313, CP. As hipóteses de fraude ou de violência constituirão estelionato, roubo ou extorsão, estes últimos possivelmente em concurso com o crime de violência arbitrária (art. 322, CP)". ${ }^{286}$

Quanto à conduta típica, a primeira parte do caput revela a modalidade peculato-apropriação, que interessa ao presente estudo, por sua íntima relação, sistemática e estrutural, com o crime de apropriação indébita.

Como não poderia deixar de ser, ao analisar o núcleo dessa modalidade de peculato, consistente na conduta de "apropriar-se", os autores reproduzem, no geral, suas considerações sobre à conduta típica do crime de apropriação indébita.

\footnotetext{
${ }^{284}$ HUNGRIA, Nelson. op. cit., 1955. p.338.

${ }^{285}$ PRADO, Luiz Regis. op. cit., 2001. p.351.

${ }^{286}$ FRAGOSO, Heleno Cláudio. op. cit., 1986. p.412.
} 
Nesse sentido, dispõe Fragoso que "apropriar-se é assenhorarse da coisa (no todo ou em parte); fazê-la própria e dela dispor como se fosse o proprietário" 287 , enquanto Noronha afirma que, no caso, "o agente comporta-se como se fosse dono do objeto material; acomoda-o ao fim que tem em vista, numa situação aparente de proprietário, quer retendo-o, quer consumindo-o, quer alienando-o etc". 288

Apesar do comportamento comissivo, existe a possibilidade de omissão, conforme relata Greco: "no entanto será possível a prática do delito via omissão imprópria quando o agente, garantidor, dolosa ou culposamente, nada fizer para impedir a prática de qualquer dos comportamentos previstos pelo tipo penal em estudo". 289

A modalidade de peculato de uso não se encontra configurado como crime em nosso ordenamento jurídico. Assim, Greco assevera que "tal como ocorre com os delitos de apropriação indébita e furto, não se pune o chamado peculato de uso, podendo, no entanto, ser o agente responsabilizado por um ilícito de natureza administrativa, que poderá trazer como conseqüência uma sanção da mesma natureza". 290

Quanto à questão central do presente trabalho, a consumação do peculato ocorre, para nossa doutrina, como sempre se advoga, com a inversão do ânimo da posse.

Nesse sentido, para Prado "a consumação se perfaz, na hipótese de apropriação, no momento em que o funcionário inverte a titularidade da posse, passando a comportar-se em relação a coisa com animus domini". ${ }^{291}$

\footnotetext{
${ }^{287}$ FRAGOSO, Heleno Cláudio. op. cit., 1986. p.414.

${ }^{288}$ NORONHA, Edgard Magalhães. op. cit., 1955. p.214.

${ }^{289}$ GRECO, Rogério.op. cit. p.410.

${ }^{290}$ GRECO, Rogério.op . cit. p.412.

${ }^{291}$ PRADO, Luiz Regis. op. cit., 2001. p.352.
} 
Noronha, aliás, faz remissão expressa à apropriação indébita ao explicar que "na hipótese de apropriação, completa-se o delito, nos mesmos termos em que se dá o crime do art. 168 (n. 556), isto é, quando o agente transforma sua posse ou detenção em domínio, executa atos de dono, passa a dispor da coisa como se tivesse a propriedade, não mais agindo em nome e no interesse de quem lhe confiou ou conferiu a posse". ${ }^{292}$

Desta forma, Bitencourt, por todos, restabelece a questão da tentativa, nos termos já anteriormente vistos, ao afirmar que "a despeito da dificuldade de sua comprovação, a identificação da tentativa fica na dependência da possibilidade concreta de se constatar a exteriorização do ato de vontade do sujeito, capaz de demonstrara alteração da intenção do agente de apropriar-se da coisa pertencente ao Poder Público de que detém a posse". ${ }^{293}$

Greco acompanha o mesmo raciocínio, uma vez que entende tratar-se de crimes plurissubsistentes, sendo possível o raciocínio em relação à tentativa, mas para tanto, deve ser analisado o caso concreto, uma vez que o inter criminis possa ser fracionado. ${ }^{294}$

Mais uma vez se repete o roteiro baseado na afirmação do caráter formal da conduta apropriativa. Mesmo afirmando-se o caráter material do delito, nega-se a possibilidade de tentativa ou restringe-se seu alcance aos casos de conduta plurissubsistente (o que é próprio dos crimes formais).

Daí porque, ainda que insistentemente, há que se reiterar a afirmação de fundamental importância, que afinal é a própria tese apresentada no presente trabalho, segundo o qual, por se tratarem as apropriações (em geral) de crimes materiais, cuja consumação se dá no momento em que se impõe ao legítimo proprietário, na realidade concreta, um obstáculo ao exercício de um dos poderes imanentes ao domínio, há que se reconhecer a tentativa sempre que

\footnotetext{
${ }^{292}$ NORONHA, Edgard Magalhães. op. cit., 1955. p.215/216.

${ }^{293}$ BITENCOURT, Cezar Roberto. op. cit., 2004. p.18..

${ }^{294}$ GRECO, Rogério. Curso de direito penal. Niterói, RJ: Impetus, 2006. p.409.
} 
realizada uma conduta típica o resultado não ocorrer por circunstância alheia à vontade do agente.

No caso do peculato-apropriação não é diferente. Embora a consideração da presença da administração pública no tipo penal, como bem jurídico a ser protegido, pudesse induzir à conclusão de que o crime poderia se consumar com a mera conduta do agente, a exemplo da concussão, a utilização do núcleo típico apropriar-se impede a solução diferenciadora e reafirma a natureza material do delito. Daí porque, pelas razões já expostas, também se deve reconhecer a possibilidade de reconhecimento da tentativa de peculatoapropriação no direito penal brasileiro. 


\section{CONCLUSÕES}

A doutrina e a jurisprudência brasileiras sobrevalorizam o elemento subjetivo do delito de apropriação indébita, de tal maneira que a própria ação típica é vista, fundamentalmente, como a mera exteriorização daquele elemento subjetivo, sem valor em si, de forma a caracterizar o momento consumativo do delito como aquele em que se inverte o animus da posse.

Tal entendimento acaba por levar à atribuição, ainda que inconsciente, de um caráter formal ao delito de apropriação indébita. Assim, mesmo afirmando se tratar de crime material, que admite tentativa, a maioria dos autores brasileiros acaba por inadmiti-la ou por admiti-la de forma restrita e casuística, sem qualquer critério sólido de sua aferição.

A falta de consciência desse problema e, portanto, da sua explicitação, acaba por dar aparência de uniformidade e coerência ao tema, sob o qual, na verdade, subjaz uma contradição capaz de inviabilizar a solução de algumas questões particulares, que apesar de pouco frequentes, não deixam de merecer o mesmo apuro técnico na busca da solução justa.

Nesse sentido, o critério mais utilizado para a fixação do momento consumativo, em tudo ligado à exteriorização do animus rem sibi habendi, acaba por se mostrar inseguro e ineficiente, pois, nem sempre se pode precisar o momento ou o local em na qual esta teria ocorrido.

De outro lado o critério mais utilizado para a verificação da possibilidade de tentativa, consistente em verificar se se trata de conduta unissubsistente (que não admitiria tentativa) ou plurissubsiente (que a admitiria) não é correto nem suficiente. Se é verdade que se pode admitir a tentativa nos casos de conduta plurrissubsistente que ainda não se esgotou, também é verdadeiro que se pode conceber situações em que condutas unissubsitentes - ou 
mesmo plurissubsistentes, já devidamente esgotadas - não produzam lesão à propriedade por circunstância alheia à vontade do agente.

De outro lado, a atribuição de natureza formal ao delito de apropriação indébita (explícita no direito italiano e implícita no direito brasileiro) acaba por levar à desproporcional punição, por crime consumado, de condutas que em nada atingiram o bem jurídico protegido pelo tipo penal, qual seja, a propriedade.

Daí porque há que se descartar por completo a idéia, ainda que velada ou temperada, de que a mera revelação do elemento subjetivo possa representar a essência do delito de apropriação indébita ou o seu momento consumativo. Embora, na maioria dos casos a conduta apropriativa se faça acompanhar do resultado lesivo à propriedade, há de se reforçar a idéia de que o resultado típico da apropriação indébita pode, por separado da conduta, não ocorrer; o que nos revela, aliás, o caráter material do crime de apropriação indébita e evidencia a natural possibilidade de tentativa do delito.

Há que se verificar, nesse sentido, que a compreensão do próprio bem jurídico em questão também revela a natureza material do delito. Deve-se reputar o crime de apropriação indébita como crime contra a propriedade (e também contra a liberdade de disposição sobre a coisa), que só se consuma, portanto, no momento em que se impõe, na realidade concreta, um obstáculo ao exercício, pelo legítimo proprietário, de um dos poderes que são imanentes. Ao domínio.

Deve se verificar, também, que a própria estrutura da conduta apropriativa, em sua configuração real, no mundo dos fatos, nos indica essa separação entre ação e resultado e, portanto, a natureza material do delito. A idéia de apropriação pode e deve ser vista sob um duplo aspecto: a apropriação como ação e apropriação como resultado. A utilização do mesmo vocábulo para representar os dois fenômenos e a frequente ocorrência conjunta destes não 
desnatura sua relação de independência e permitem o reconhecimento da natureza material do crime. Havendo duas relações distintas sobre a coisa (a do proprietário e a do possuidor) não há que se dizer que a alteração fática da relação do possuidor com a coisa (apropriação em sentido estrito), leve, sempre e automaticamente, à modificação da relação do proprietário com a coisa (expropriação). A liberdade de disposição patrimonial do proprietário somente será vulnerada, e este será o momento de consumação do delito, se a ação típica, levar à criação concreta de obstáculo ao exercício das faculdades próprias ao domínio.

O entendimento de que o crime estaria consumado no momento ou local onde se produz a lesão à propriedade, ademais, é mais seguro e adequado, pois sempre se pode verificar onde e quando o real proprietário poderia exercer seu direito e foi impedido de fazê-lo.

Há que se descartar, por fim, a necessidade de atingimento do patrimônio, sob seu aspecto econômico, para a configuração do delito. Atingida a propriedade (ou a liberdade de disposição do proprietário sobre a coisa) está consumado o delito. Não se afasta porém a possibilidade de utilização do princípio da insignificância. A proteção da norma sobre a propriedade deve guardar um sentido ético. Inexistindo outro valor envolvido na relação de propriedade (tal como um valor sentimental, histórico ou religioso) e sendo o valor patrimonial da coisa de ínfima importância, nada obsta, a prudente aplicação do princípio da insignificância como boa medida de política criminal. 


\section{REFERÊNCIAS BIBLIOGRÁFICAS}

Alves, José Carlos Moreira, Posse - 1: Evolução Histórica, $1^{\mathrm{a}}$ ed., Rio de Janeiro, Editora Forense, 1999.

AngelotTI, Dante, Le Appropriazioni Indebite, $2^{\mathrm{a}}$ edizione, Milano, Società Editrice Libraria, 1933.

Antolisei, Francesco, Manuale di Diritto Penale, vol. 1, Milano, Giuffrè, 1994.

Bajo Fernandez, Miguel, Manual de Derecho Penal - Parte General - Delitos Patrimoniales y Económicos, T. II, Madrid, Ceura, 1987.

Bartoli, Roberto, La Distinzione tra Appropriazionne e Distrazione e le Attuali Esigenze di Tutela Patrimoniale, in Diritto Penale e Processo, IPSOA Scuola d'Imprensa, Anno VII, setembro, 2001.

Batista, Nilo, Introdução Crítica ao Direito Penal Brasileiro, $10^{\mathrm{a}}$ ed., Rio de Janeiro, Revan, 2005.

Beccaria, Cesare Marchesi di, Dos Delitos e das Penas, São Paulo, Revista dos Tribunais, 1999.

Bitencourt, Cezar Roberto, Tratado de Direito Penal - Parte Especial, vol. 3, São Paulo, Saraiva, 2009.

Tratado de Direito Penal - Parte Especial, vol. 3, $7^{\mathrm{a}}$ ed., São Paulo, Saraiva, 2011.

Brasil, Código Penal, op. cit. (art. 312). 
Bueno, Paulo Thomaz Alves da Cunha, Notícia Histórica do Direito Penal no Brasil, in BitTAR, Eduardo C.B, História do Direito Brasileiro - Leituras da Ordem Jurídica Nacional, São Paulo, Atlas, 2003.

Busson, Elena. Operazioni Infragruppo e Bancarotta Mediante Distrazione in Diritto Penale e Processo, IPSOA Scuola d'Imprensa, Anno VII, junho, 2001.

CALÒ, Rafaela. Infedeltà Patrimonale - Appropriazione Indébita - Rapporti tra Fattispecie - Specialità Recíproca Sussistenza (C.c. art. 2634; C.p.,art. 646). in Rivista Italiana di Diritto e Procedura Penale, anno XLIX, Milano, Giuffrè Editore, 2006.

CÂmarA, Guilherme Costa, Beccaria e o Pensamento Jurídico-Criminal, in Revista Brasileira de Ciências Criminais, São Paulo, Revista dos Tribunais, julset, 2003.

CAPez, Fernando, Curso de Direito Penal - Parte Especial, vol. 2, São Paulo, Saraiva, 2011.

Chiaraviglio, Gianmaria. Appropriazione Indébita e Infedeltà Patrimoniale in Rivista dei Dottori Commercialisti, anno LVI, Milano, Giuffrè Editore, 2005.

Código Penal Alemão, trad. de Lauro de Almeida, São Paulo, Bushatsky, 1974.

Conde-Pumpido Ferreiro, Candido, Apropriaciones Indebidas, Valencia, Tirant lo Blanch, 1997.

De la Mata Barranco, Norberto J., Tutela Penal de la Propiedad y Delitos de Apropiación - El Dinero como Objeto Material de los Delitos de Hurto y Apropiación Indebida, Barcelona, PPU, S.A., 1994.

Delmanto, Celso, et. al., Código Penal Comentado, Rio de Janeiro, Renovar, 2002. 
ENGISCH, Karl, Introdução ao Pensamento Jurídico, Lisboa, Calouste Gulbenkian, 2001.

Estefam, André, Direito Penal - Parte Especial, vol. 2, São Paulo, Saraiva, 2010.

FABricius, Dirk, Posición Politico-Partidarista y Capacidad de Comprensión en la Ciencia Jurídico-Criminal - Consideraciones Desde una Perspectiva EtnoPsicoanalítica, trad. Percy García Cavero, in La Insostenible Situación del Derecho Penal, Granada, Comares, 2000.

FARIA, Bento de, Código Penal Brasileiro, vol. 4, Rio de Janeiro, Livraria Jacintho Editora, 1943.

FERrARI, Simone, Diritto Penale - Appropriazione Mediante Ritenzione, in Giurisprudenza Italiana, Torino, UTET, Aprile 2008.

FiandacA, Giovanni, Musco, Enzo, Diritto Penale - Parte Speciale - I Delitti contro il Patrimonio, vol. II, T. 2, Bologna, Zanichelli, 2011.

FIORE, Carlo, I Presuposti Culturali e Istituzionali del Diritto Penale Vigente, Torino, UTET, 1993.

Fragoso, Heleno Cláudio, Lições de Direito Penal - Parte Especial, vol. I, $8^{\mathrm{a}}$ ed., Rio de Janeiro, Forense, 1986.

Gambardella, Marco. Lábolizione Del Delito di Bancarotta Imprópria Comesso nell'ambito di Società in Ammnistrazione Controllata, in Cassazione Penale, $\mathrm{n}^{\mathrm{o}}$ 11, 2009.

Gomes Júnior, João Florêncio de Salles, O Crime de Extorsão no Direito Penal Brasileiro, São Paulo, Quartier Latin, 2012. 
Gomes, Orlando, Direitos Reais, 21 a ed., Rio de Janeiro, Editora Forense, 2012.

Greco, Rogério, Curso de Direito Penal - Parte Especial, vol. 3, Niterói, Impetus, 2006.

Houaiss, Antônio e Villar, Mauro de Salles, Dicionário Houaiss da Língua Portuguesa,19a ed., Rio de Janeiro, Objetiva, 2009.

Hungria, Nélson, Comentários ao Código Penal, vol. VII, Rio de Janeiro, Forense, 1955.

JAKOBS, Günther, Derecho penal - Parte general, trad. Joaquin Cuello Contreras, Jose Luis Serrano Gonzalez de Murillo, Madrid, MarcialPons, 1997.

Jescheck, Hans-Heinrich, Weigend, Thomas, Tratado de Derecho Penal Parte General, trad. Miguel Olmedo Cardenete, Granada, Comares, 2002.

Jesus, Damásio Evangelista de, Direito Penal, vol. 2, São Paulo, Saraiva, 1997.

Jimenez DE ASÚA, Luis. Tratado de Derecho Penal, vol. 1, Buenos Aires, Lousada, 1950.

LiszT, Franz Von, Tratado de Direito Penal Allemão.

Mantovani, Ferrando, Diritto Penale - Parte Generale, $7^{\mathrm{a}}$ ed., Padova, CEDAM, 2011.

Mantovani, Ferrando, Diritto Penale - Parte Speciale II - Delitti contro il Patrimonio, $4^{\text {a }}$ ed., Padova, CEDAM, 2012.

Manuel Rojas, Ricardo, Las Contradicciones del Derecho Penal, Buenos Aires, Ad-Hoc, 2000. 
Manzini, Vincenzo, Trattato di Diritto Penale Italiano, vol. 9, Torino, Ariel, 1952.

MarinuCci, Giorgio, Dolcini, Emilio, Corso di Diritto Penale, vol.1, Milano, Giuffrè, 1999.

MASUCCI, Massimiliano. Vantaggi Del Gruppo e dell'imprensa Collegata nel Governo Penale degli Abusi di Gestione, in Rivista Trimestrale di Diritto Penale dell'Economia, Anno XVII, no 3-4, CEDAM, 2004.

Militello, Vizenzo. Gli Abusi nel Patrimônio di Societá Controllate e Le Relazioni fra Appropriazione e Distrazione in Rivista Italiana di Diritto e Procedura Penale, anno XXXIV, Milano, Giuffrè Editore, 1991.

Mirabete, Júlio Fabbrini, Manual de Direito Penal, vol. 2, $26^{\mathrm{a}}$ ed., São Paulo, Atlas, 2009.

MINISTÉRIO DA JUSTIÇA. Diagnóstico Preliminar do Sistema Penal Brasileiro e Primeiras Propostas para sua Reformulação da Comissão de Reforma do Sistema Penal Instituída pela Portaria do Ministro da Justiça, ${ }^{\circ}$ $531,29.09 .1999$.

Moccia, Sergio, Tutela Penale del Patrimonio e Principi Constituzionale, Padova, CEDAM, 1988.

Muñoz Conde, Francisco, Derecho Penal - Parte Especial, Valencia, Tirant lo Blanch, 2009.

NARDONE, Roberta, L'Infedeltà Patrimoniale degli Amministratori e l'Appropriazione Indebita, in Rivista Penale dell'Econonomia, fascículo 1, 1995.

Noronha, Edgard Magalhães, Direito Penal, vol. 2, 32a ed., São Paulo, Saraiva, 2001. 
NuccI, Guilherme de Souza, Manual de Direito Penal - Parte Geral - Parte Especial, São Paulo, Revista dos Tribunais, 2005.

PedrazZI, Cesare, Appropriazione Indebita, in Enciclopedia del Diritto, vol. II, Varese, Giuffrè, 1958.

Penteado, Luciano Camargo, Direito das Coisas, $1^{\mathrm{a}}$ ed., São Paulo, Editora Revista dos Tribunais, 2008.

Pérez BARberÁ, Gabriel, El Dolo Eventual - Hacia el Abandono de la Idea de Dolo como Estado Mental, Buenos Aires, Hammurabi, 2011.

Petrocelli, Biagio, L'Appropriazione Indebita, Napoli, Alberto Morano, 1933.

Polaino Navarrete, Miguel, El Injusto en la Teoría del Delito, Corrientes, MAVE, 2000.

PorciúnCUlA, José Carlos, La Exteriorización de lo Interno - Sobre la Relación entre lo Objetivo y lo Subjetivo en el Tipo Penal, tese apresentada à Universidade de Barcelona, 2013.

PotT, Christine, La Perdida e Contenido del Principio de Legalidad y su Manifestación en la Relación entre el Delito de Encubrimiento por Funcionario (\$258.a StGB) y el Sobreseimiento (\$153 sigs. StPO), trad. Elena Iñigo Corroza y Gillermo Benlloch Petit, in La Insostenible Situación del Derecho Penal, Granada, Comares, 2000.

Prado, Luiz Regis, Curso de Direito Penal Brasileiro - Parte Especial, vol. 2, 9a ed., São Paulo, Editora dos Tribunais, 2010. 
Curso de Direito Penal Brasileiro - Parte Especial, arts.

121 a 183, São Paulo, Revista dos Tribunais, 2000.

Quintero Ripollés, Antonio, Tratado de la Parte Especial del Derecho PenalInfracciones Patrimoniales de Apoderamento, T. II, Madrid, Civitas, 1977.

RaGNO, Giuseppe, Il Delito di Estorsione, Milano, Giuffrè, 1966.

REALE, Miguel, Filosofia do Direito, São Paulo, Saraiva, 2002.

Reale Junior, Miguel, Instituições de Direito Penal, Rio de Janeiro, Forense, 2002.

, Teoria do Delito, $2^{\mathrm{a}}$ ed., São Paulo, Revista dos

Tribunais, 2000.

Robles Planas, Ricardo, Dogmática de los Limites al Derecho Penal, in Hirsch, Andrew Von, Seelmann, Kurt, Wohlers, Wolfgang, Robles Planas, Ricardo (ed.), Limites al Derecho Penal - Principios Operativos en la Fundamentación del Castigo, Barcelona, Atelier, 2012.

Rodrigues, Silvio, Direito Civil - Direito das Coisas, vol. 5, $27^{\text {a }}$ ed., São Paulo, Saraiva, 2002.

SÁinz Cantero, José A., La Ciencia del Derecho Penal y su Evolución, Barcelona, Bosch, 1970.

SPIRITO, Ugo, Storia del Diritto Penale Italiano, Torino, Fratelli Bocca, 1932.

Stratenwerth, Günther, Derecho Penal. Parte General - El Hecho Punible, trad. Manuel Cancio Meliá e Marcelo Sancinetti, Madrid, Civitas, 2005. 
Tiedmann, Klaus, Poder Económico y Delito - Introducción al Derecho Penal Económico y de la Empresa, trad. Amélia Mantilla Villegas, Barcelona, Ariel, 1985.

Toledo, Francisco de Assis, Princípios Básicos de Direito Penal, São Paulo, Saraiva, 1994.

Vallini, Antonio. Il Commento in Diritto Penalle e Processo, $\mathrm{n}^{\circ}$ 9, IPSOA Scuola d'Imprensa, 2005.

VASSALI, Giuliano, Novíssimo Digesto Italiano, Torino, UTET, 1995.

Vives Antón, Tomás S., GonzÁlez CussaC, José L., Delitos Contra el Patrimonio y el Orden Socioeconómico - (I) Introducción General, in VIVES Antón, Tomás S., Ors Berenguer, Enrique, Carbonell Mateu, Juan Carlos, Gonzáles Cussac, José Luis, Martínez-Buján Pérez, Carlos, Derecho Penal - Parte Especial, Valencia, Tirant lo Blanch, 2010.

ZAFFAROni, Eugenio Raúl, ALAGIA, Alejandro, SLOKAR, Alejandro, Derecho Penal - Parte General, Buenos Aires, Ediar, 2000.

Zaffaroni, Eugênio Raúl, Pierangeli, José Henrique, Manual de Direito Penal Brasileiro, São Paulo, Revista dos Tribunais, 2001.

Zugaldía Espinar, José Miguel, Delitos contra la Propiedad y el Patrimonio, Madrid, Akal, 1988.

\section{JURISPRUDÊNCIA:}

Cass. 11 luglio 2002, in CED Cass. 222657

STF, $1^{\text {a }}$ Turma, HC 87.846-6, Rel. Sepúlveda Pertence, J. 28.03.2006, DJU 19.05.2006. 
STF, $1^{\text {a }}$ Turma, HC 87.846-6, Rel. Sepúlveda Pertence, J. 28.03.2006, DJU 19.05.2006.

STF, $2^{\text {a }}$ Turma, RHC 96.814-7 PA, Rel. Eros Grau, J. 12/05/2009, DJe n ${ }^{\circ} 148$, 06/08/2009.

STF, 2 ${ }^{\text {a }}$ Turma, RHC 96.814-7 PA, Rel. Eros Grau, J. 12/05/2009, DJe n ${ }^{\circ} 148$ 06/08/2009.

STF, Conflito de Jurisdição n ${ }^{0}$ 2079/PR, Rel. Orosimbo Nonato.

STF, Conflito de Jurisdição nº 2186/SP, Rel. Rocha Lagoa.

STF, Conflito de Jurisdição nº 2186/SP, Rel. Rocha Lagoa.

STF, Conflito de Jurisdição, no 2079/PR, Rel. Orosimbo Nonato.

STF, RHC 54122/PR, Rel. Cordeiro Guerra.

STJ, $3^{\text {a }}$ Seção, CC 102.103/PR, Rel. Maria Thereza de Assis Moura, J. 12.08.2009.

STJ, $3^{\text {a }}$ Seção, CC 102.103/PR. Rel. Maria Thereza de Assis Moura, J. 12.08.2009.

STJ, $3^{\text {a }}$ Seção, CC 16.389/SP, Rel. Edson Vidigal, J. 26.06.1996, DJU 21.10.1996.

STJ, $3^{\text {a }}$ Seção, CC 16.389/SP, Rel. Edson Vidigal, J. 26.06.1996, DJU 21.10.1996.

STJ, $3^{\text {a }}$ Sessão, CC 355/PE, Rel. Dias Trindade, J. 31.08.1989, DJU 25.09.1989.

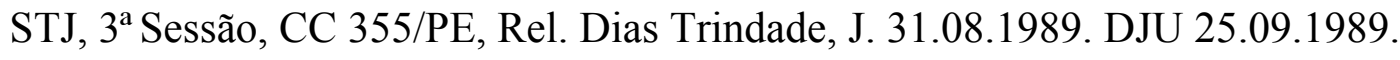


STJ, $6^{a}$ Turma, HC 73.352/SP, Rel. Carlos Fernando Mathias, J. 29.11.2007, DJe 26.05.2008.

STJ, 6 a Turma. HC 73.352/SP, Rel. Carlos Fernando Mathias, J. 29.11.2007, DJe 26.05.2008.

STJ, CC 1.646/MG, Rel. Flaquer Scartezzini, DJU 03.06.1991.

STJ, CC 1.646/MG, Rel. Flaquer Scartezzini, DJU 03.06.1991.

STJ, CC 255/PE, Rel. Dias Trindade, DJU 25.09.1989.

STJ, CC 255/PE, Rel. Dias Trindade, DJU 25.09.1989. 